SIMULATION OF GROUND-WATER FLOW AND THE MOVEMENT OF SALINE WATER IN THE HUECO BOLSON AQUIFER, EL PASO, TEXAS, AND ADJACENT AREAS

By George E. Groschen

U.S. GEOLOGICAL SURVEY

Open-File Report 92-171

Prepared in cooperation with the

EL PASO WATER UTILITIES-PUBLIC SERVICE BOARD, TEXAS WATER DEVELOPMENT BOARD, and

U.S. DEPARTMENT OF DEFENSE 


\section{CONTENTS}

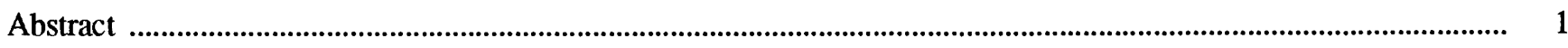

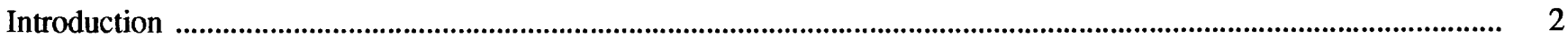

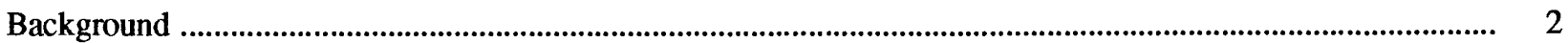

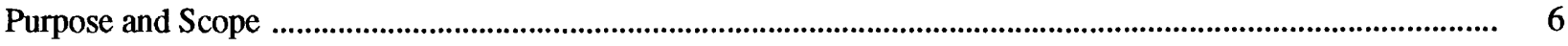

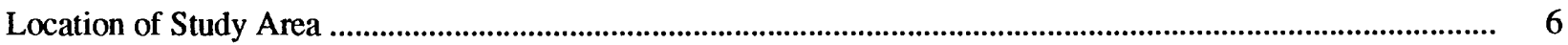

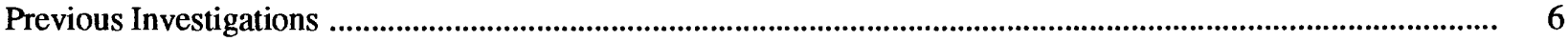

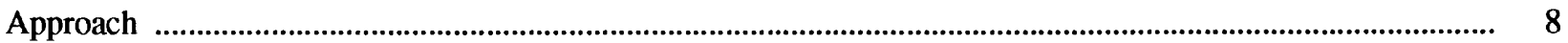

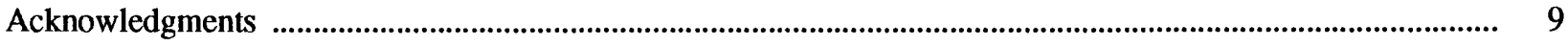

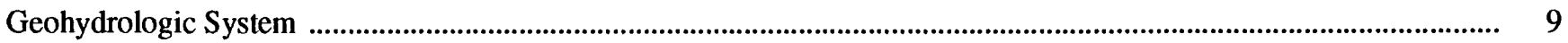

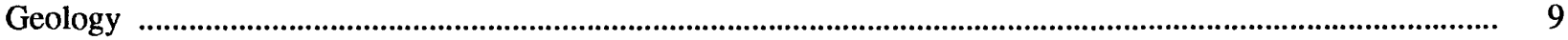

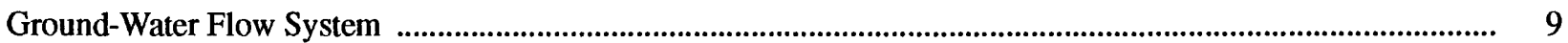

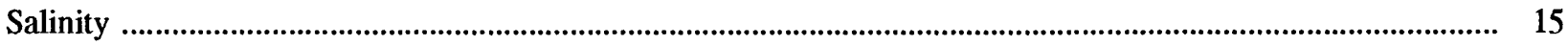

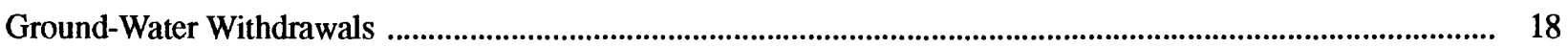

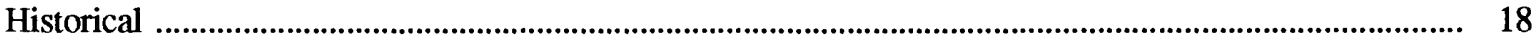

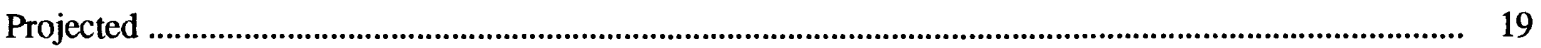

Simulation of Ground-Water Flow and Solute Transport ..................................................................................

General Description of Modular Model ................................................................................................ 22

Model Design and Parameter Definition ................................................................................................... 24

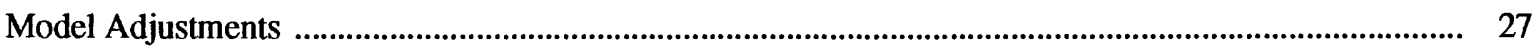

General Description of Solute-Transport Model .......................................................................................... 27

Model Design and Parameter Definition ..................................................................................... 29

Model Adjustments ................................................................................................................................... 38

Sensitivity of Solute-Transport Model to Data Uncertainty and Reliability of Simulated Results ......................... 38

Aquifer Properties and Conditions ............................................................................................................... 47

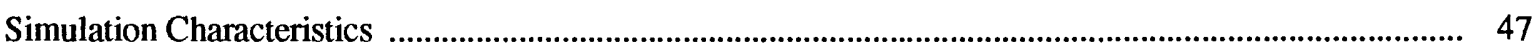

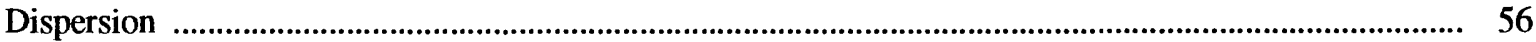

Simulation of Water-Level Changes and Movement of Saline Water ............................................................. 62

Simulated Effects of Historical Ground-Water Development ........................................................................ 62

Simulated Effects of Projected Ground-Water Development ................................................................... 67

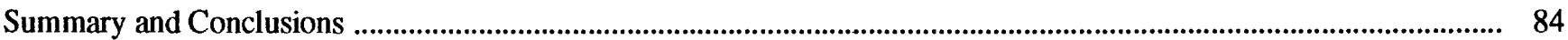

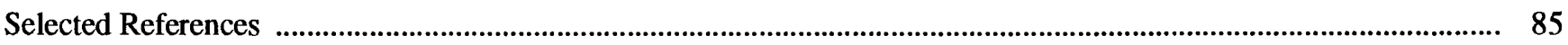

\section{FIGURES}

1. Map showing location of study area, area underlain by river alluvium, and physiographic features

2. Map showing location of traces of two hydrogeologic sections along selected municipal-supply wells and area underlain by river alluvium

3. Generalized section showing relation between municipal wells and dissolved-solids concentrations in river alluvium and bolson deposits, Hueco bolson aquifer, January 1984

4. Generalized section showing relation between municipal wells and dissolved-solids concentrations in the Hueco bolson aquifer, along the Rio Grande, January 1984 
5-8. Maps showing:

5. Estimated predevelopment water-table altitude, Hueco bolson aquifer ...................................................... 10

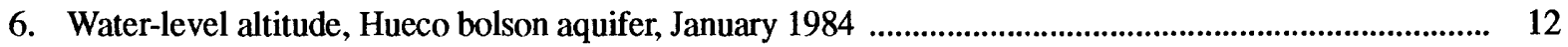

7. Estimated water-level changes, Hueco bolson aquifer, 1903-84 ........................................................ 13

8. Areal distribution of dissolved-solids concentrations in the Hueco bolson aquifer, 1980 ....................... 17

9. Graph showing withdrawals from the Hueco bolson aquifer in the El Paso-Ciudad Juarez area, 1903-83

10-12. Maps showing:

10. Location of wells pumped from the Hueco bolson aquifer in the El Paso-Ciudad Juarez area, 1983

11. Finite-difference grid for model layer 1 and boundary conditions of the modular model overlain on study area

12. Finite-difference grid for node-layer $\mathrm{A}$ and boundary conditions of the heat- and solutetransport three-dimensional model overlain on study area

13. Generalized section of the hydrogeologic system showing vertical grid used in the modular and heat- and solute-transport three-dimensional (HST3D) simulations of the Hueco bolson aquifer

14. Generalized section of the hydrogeologic system along the Rio Grande showing the vertical grid used in the heat- and solute-transport three-dimensional (HST3D) simulation of the Hueco bolson aquifer

15. Schematic maps showing distribution of horizontal intrinsic permeability in aquifer layers

16-21. Maps showing:

16. Estimated predevelopment dissolved-solids concentrations in node-layers A, B, C, and D of the Hueco bolson aquifer

17. Simulated changes in dissolved-solids concentrations for 1903-58 in node-layers A, B, and $\mathrm{C}$ of the Hueco bolson aquifer

18. Differences between estimated predevelopment water table in the Hueco bolson aquifer and simulated predevelopment water levels for node-layers A and B

19. Hydraulic gradient from node-layer A to node-layer $B$ for simulation of predevelopment conditions in the Hueco bolson aquifer

20. Differences between observed January 1984 water levels in the Hueco bolson aquifer and simulated water levels for December 1983 in node-layers A and B

21. Hydraulic gradient from node-layer A to node-layer B for simulation of Hueco bolson aquifer conditions, December 1983

22-25. Graphs showing:

22. Simulated vertical-head distribution and unit-flow rates involving two adjacent pumped wells in a hypothetical aquifer showing effects of using standard and Thiem approximation to simulate per-layer flow to wells

23. Simulated vertical-head and dissolved-solids concentration distributions and unit-flow rates involving one pumped well in a hypothetical aquifer showing effects of fluid density and ratio of horizontal to vertical aquifer permeabilities on potential upconing of saline water

24. Simulated vertical-head and dissolved-solids concentration distributions and unit-flow rates involving two adjacent pumped wells in a hypothetical aquifer showing effects of various aquifer properties and conditions and interference between wells on movement of saline water to wells

25. Solute dispersion simulated by analytical solution, plug flow with no dispersion, and (A) one heat- and solute-transport three-dimensional (HST3D) backward-in-space finite-difference solution, and one HST3D centered-in-space finite-difference solution and (B) two HST3D centered-in-space finite-difference solutions with different nodal spacings and dispersivities 
26-36. Maps showing:

26. Simulated December 1983 water levels in node-layers A, B, C, D, and E of the Hueco bolson aquifer

27. Simulated water-level changes in node-layers A and B of the Hueco bolson aquifer, 1903-84

28. Simulated dissolved-solids concentrations in node-layers A, B, C, and D of the Hueco bolson aquifer, 1984

29. Simulated changes in dissolved-solids concentrations in node-layers A, B, and C of the Hueco bolson aquifer, 1958-84

30. Simulated water-level altitudes for the year 2000 in node-layers A, B, C, D, and E of the Hueco bolson aquifer in response to two estimates of projected (1984-2000) ground-water withdrawals

31. Simulated water-level changes, 1903-2000, in node-layers A and B of the Hueco bolson aquifer in response to the smaller estimate of projected (1984-2000) ground-water withdrawals

32. Simulated water-level changes, 1903-2000, in node-layers A and B of the Hueco bolson aquifer in response to the larger estimate of projected (1984-2000) ground-water withdrawals

33. Simulated-hydraulic gradient, January 2000 , from node-layer A to node-layer B of the Hueco bolson aquifer in response to both estimates of projected (1984-2000) ground-water withdrawals

34. Simulated dissolved-solids concentrations, January 2000 , in node-layers A, B, C, and D of the Hueco bolson aquifer in response to two estimates of projected (1984-2000) ground-water withdrawals

35. Simulated changes in dissolved-solids concentrations, 1984-2000, in node-layers A, B, and $\mathrm{C}$ of the Hueco bolson aquifer in response to the smaller estimate of projected (19842000) ground-water withdrawals

36. Simulated changes in dissolved-solids concentrations, $1984-2000$, in node-layers A and B of the Hueco bolson aquifer in response to the larger estimate of projected (1984-2000) ground-water withdrawals

\section{TABLES}

1. Estimates of net recharge, underflow, river-leakage rates, and total well withdrawals of the Hueco bolson aquifer

2. Estimates of ground-water withdrawal rates used for water-use projections

3. Summary of errors between estimated predevelopment water levels in the Hueco bolson aquifer and simulated predevelopment water levels in node-layers A and B of the ground-water flow and solute-transport model

4. Summary of errors between observed January 1984 water levels in the Hueco bolson aquifer and simulated December 1983 water levels in node-layers A and B of the ground-water flow and solute-transport model

5. Summary of sensitivity of simulated heads and dissolved-solids concentrations to data uncertainties

6. Summary of sensitivity of simulated heads and dissolved-solids concentrations to model characteristics

7. Properties and conditions that were held constant in the well-test simulations

8. Properties and conditions that were varied in and results from the single-well test simulations shown in figure 23

9. Properties and conditions that were varied in and results from the two-well test simulations 


\section{CONVERSION FACTORS AND VERTICAL DATUM}

\begin{tabular}{|c|c|c|}
\hline Multiply & By & To obtain \\
\hline acre-foot (acre-ft) & 0.001233 & cubic hectometer \\
\hline acre-foot per year (acre-ft/yr) & 0.001233 & cubic hectometer per year \\
\hline cubic foot per second $\left(\mathrm{ft}^{3} / \mathrm{s}\right)$ & 0.02832 & cubic meter per second \\
\hline foot $(\mathrm{ft})$ & 0.3048 & meter \\
\hline foot per day (ft/d) & 0.3048 & meter per day \\
\hline foot per second $(\mathrm{ft} / \mathrm{s})$ & 0.3048 & meter per second \\
\hline foot squared $\left(\mathrm{ft}^{2}\right)$ & 0.09290 & meter squared \\
\hline foot squared per second $\left(\mathrm{ft}^{2} / \mathrm{s}\right)$ & 0.09290 & meter squared per second \\
\hline inch (in.) & 25.4 & millimeter \\
\hline mile (mi) & 1.609 & kilometer \\
\hline million gallons per day (Mgal/d) & 0.04381 & cubic meter per second \\
\hline pound per cubic foot $\left(\mathrm{lb} / \mathrm{ft}^{3}\right)$ & 16.02 & kilogram per cubic meter \\
\hline pound per square inch $\left(\mathrm{lb} / \mathrm{in}^{2}\right)$ & 6.895 & kilopascal \\
\hline degree Fahrenheit $\left({ }^{\circ} \mathrm{F}\right)$ & $\begin{array}{c}\text { Temperature } \\
{ }^{\circ} \mathrm{C}=5 / 9 \times\left({ }^{\circ} \mathrm{F}-32\right)\end{array}$ & degree Celsius \\
\hline
\end{tabular}

Sea level: In this report, "sea level" refers to the National Geodetic Vertical Datum of 1929--a geodetic datum derived from a general adjustment of the first-order level nets of the United States and Canada, formerly called Sea Level Datum of 1929. 


\title{
Simulation of Ground-Water Flow and the Movement of Saline Water in the Hueco Bolson Aquifer, El Paso, Texas, and Adjacent Areas
}

\author{
By George E. Groschen
}

\begin{abstract}
The Hueco bolson aquifer is being pumped at increasing rates to supply water for El Paso, Texas, and Ciudad Juarez, Mexico. Water-use projections for 1984-2000 indicate that the upward trend in pumping rates probably will continue, which will put an increasing burden on the limited freshwater resources of the aquifer. Near El Paso, saline water in the Rio Grande alluvium overlies freshwater in bolson deposits. Withdrawal of ground water has created a large cone of depression in the water table that is centered approximately under the El Paso-Ciudad Juarez urban area. The maximum depth of this cone in January 1984 was about 140 feet below the pre-development (before 1903) water table.

The principal concern of the water-management agencies involved with the water supply for El Paso and Ciudad Juarez, and of the U.S. Department of Defense at Fort Bliss to the north of these cities is that the saline water underlying and surrounding the freshwater in the bolson deposits will begin to move into the intensively pumped freshwater zone. Intrusion of large volumes of saline water would contaminate the freshwater and make it unusable for municipal and industrial supply. Changes in ground-water quality, indicated by an increase in dissolved-solids concentrations in well water, have occurred near the El Paso airport and near the Rio Grande.
\end{abstract}

This study focused primarily on simulation of historical and present (1984) ground-water flow and salinity of water in the Hueco bolson aquifer, to help understand and project the movement of saline water in the aquifer to January 2000.

The objective of this study was to understand the movement of water resulting from historical and projected pumping, using numerical simulation of the transport of saline water. Results of the numerical simulations indicate that historical withdrawals of ground water have caused only slight movement of saline water, except near the Rio Grande. The saline water probably has moved laterally from the river alluvium into the bolson deposits and towards the wells located north and south of the river. Some downward movement of saline water has occurred; this movement was caused by withdrawals from wells screened only in the freshwater zone beneath the river alluvium. Simulation results further indicate that upconing of saline water into well screens probably is not, and will not become, a substantial problem. This conclusion is based on the assumption that the aquifer is anisotropic, specifically that horizontal intrinsic permeability is much greater than the vertical permeability.

Results of the projected withdrawal simulations from 1984-2000 indicate that the general historical trend of saline-water movement probably will continue. The saline water in the Rio Grande alluvium is the major source of saline-water intrusion into the freshwater zone throughout the historical period and into the future on the basis of simulation results. Some saline water probably will continue to move downward from the Rio Grande alluvium to the freshwater below. Injection of treated sewage effluent into some wells 
will create a small zone of freshwater containing slightly increased amounts of dissolved solids in the northern area of the Texas part of the Hueco bolson aquifer. Many factors, such as well interference, pumping schedules, and other factors not specifically represented in the regional simulation, can substantially affect dissolved-solids concentrations at individual wells.

\section{INTRODUCTION}

The availability of water to meet rapidly increasing demands for industrial and municipal supplies in the city of El Paso, Texas, and Ciudad Juarez, Mexico (fig. 1), concerns not only the residents of the metropolitan area, but State and Federal officials and the people of New Mexico. The future of the international community, Fort Bliss, and other military installations is dependent on the continued availability of fresh ground water.

The zone of freshwater in the Hueco bolson aquifer that provides virtually all water supples in the area is bounded by slightly to moderately saline water below and to the east. The freshwater is overlain by slightly saline water in the Rio Grande alluvium, or in the shallow bolson deposits adjacent to the alluvium and uplands, or in both. Because the freshwater available in the Hueco bolson aquifer is being withdrawn at an increasing rate, a potential exists for the saline water to move toward the supply wells. To address concerns about the effects of such movement on water supples, the U.S. Geological Survey (USGS), in cooperation with the El Paso Water UtilitiesPublic Service Board, the Texas Water Development Board, and the U.S. Department of Defense, conducted a study. The objective of the study was to provide an improved understanding of the movement of saline water in the Hueco bolson aquifer underlying El Paso and adjacent areas.

The definitions used for freshwater and saline water in this report are modified from those of Winslow and Kister (1956) and are compatible with those of the U.S. Geological Survey (1985). Freshwater has dissolved-solids concentrations ranging from 0 to 1,000 milligrams per liter $(\mathrm{mg} / \mathrm{L})$, and saline water has dissolved-solids concentrations ranging from 1,001 to $35,000 \mathrm{mg} / \mathrm{L}$. Saline water can be classified further as slightly saline water $(1,001$ to $3,000 \mathrm{mg} / \mathrm{L})$, moderately saline water $(3,001$ to $10,000 \mathrm{mg} / \mathrm{L})$, and very saline water $(10,001$ to $35,000 \mathrm{mg} / \mathrm{L})$. Water with dissolved-solids concentrations greater than $35,000 \mathrm{mg} / \mathrm{L}$ is considered to be brine.

\section{Background}

The first well drilled for water supply in the study area yielded only saline water from the river alluvium near El Paso. Since then, discovery of freshwater supplies in the mesa area north and east of the Rio Grande (fig. 1) and elsewhere has expanded and increased the search for potable water. One of the earliest ground-water contamination studies was conducted by Slichter (1905). That report documented problems of salinity in water from private wells near the edge of the mesa area caused by the movement of slightly saline water northward from the river alluvium toward the wells. Slichter (1905) also documented the presence of moderately saline water in the river alluvium in the narrows of the Rio Grande just northwest of El Paso but determined that the movement of this water was extremely slow and of insufficient quantity to affect the Hueco bolson aquifer to the southeast.

The large drawdowns that have developed in downtown El Paso, Ciudad Juarez, and in the mesa area have completely changed the predevelopment ground-water flow system. Ground-water withdrawals greatly exceed the natural recharge rate (Meyer, 1976); therefore, freshwater in storage is decreasing. Saline water underlies and surrounds the freshwater on at least two sides in the study area. There is concern that this water might be drawn upwards and laterally into large-capacity wells (casing diameter greater than 8 in.) located near the zone of saline water. The location of traces of two sections along select municipal-supply wells and areas underlain by river alluvium is shown in figure 2. A generalized section $(A-A)$ (figs. 2,3$)$ shows the relation between the large-capacity wells used for municipal supply and the occurrence of freshwater and saline water in the river alluvium and the bolson deposits. The sections illustrate the proximity of saline water to the productive freshwater zone, the predevelopment water table (defined by water levels in shallow wells near the river), the January 1984 water table, and the potentiometric surface in the underlying bolson deposits (defined by water levels in deep wells). 


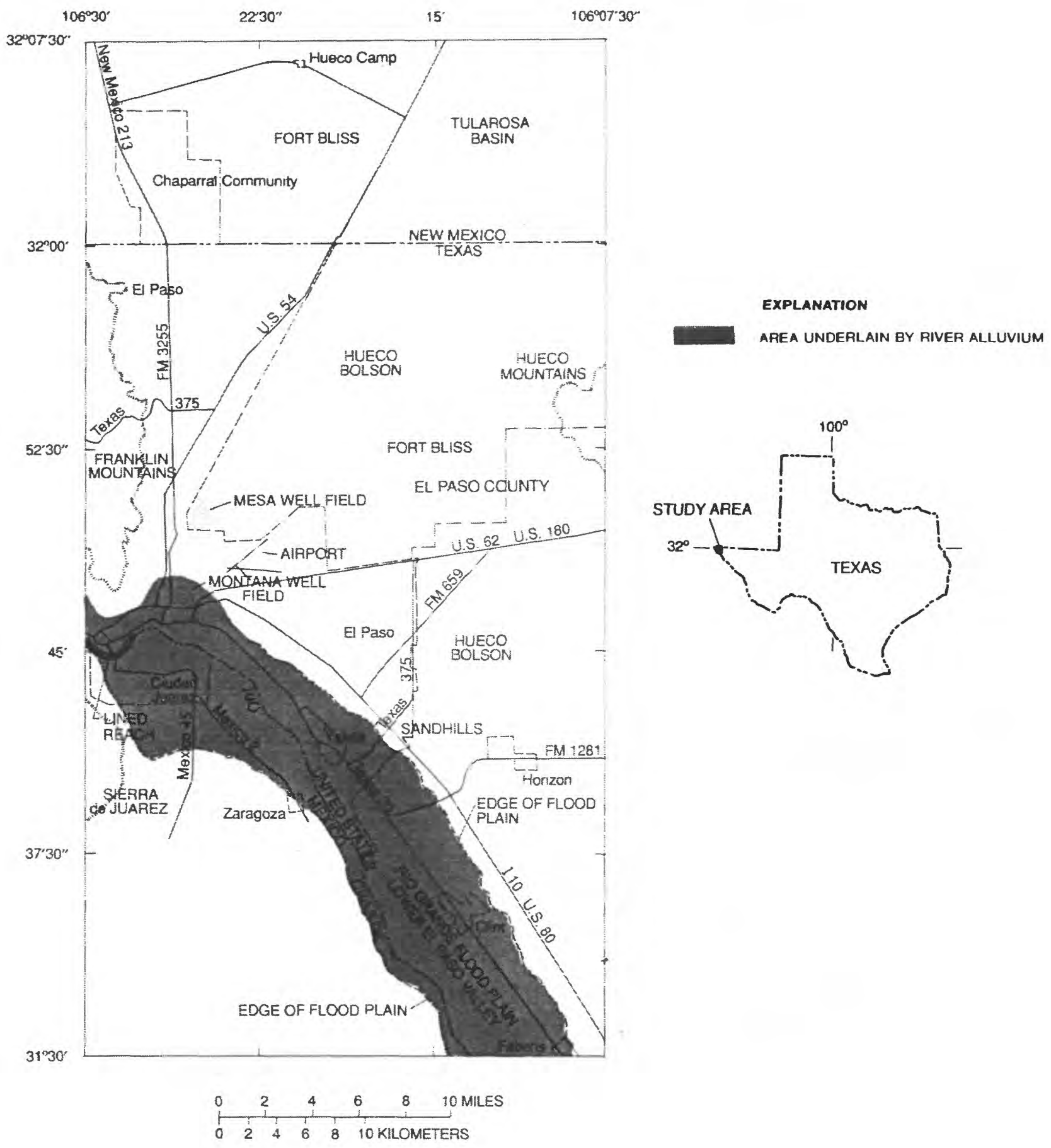

Figure 1. Location of study area, area underlain by river alluvium, and physiographic features. 


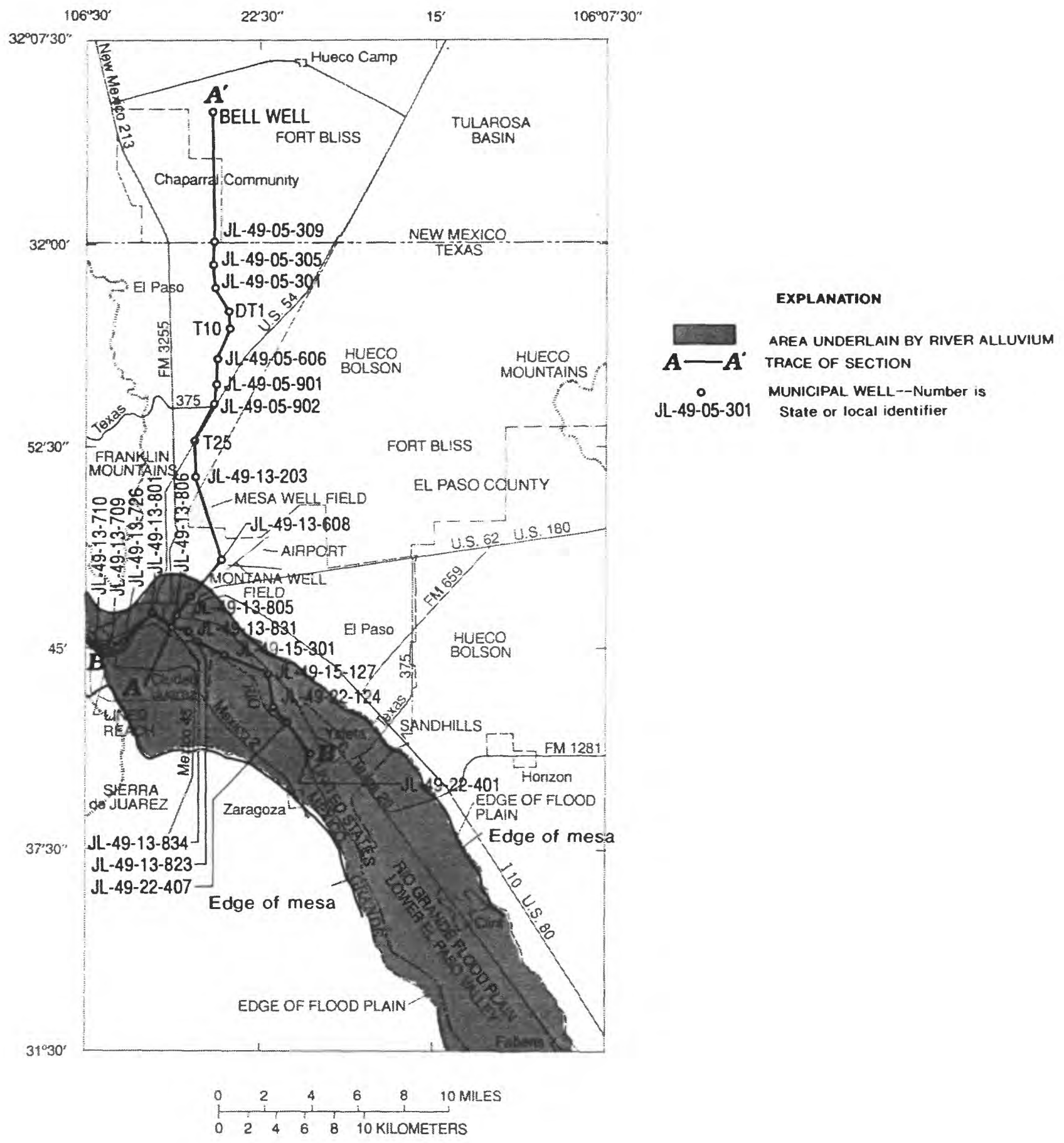

Figure 2. Location of traces of two hydrogeologic sections along selected municipal-supply wells and area underlain by river alluvium. (Modified from Thomas Cliett, El Paso Water Utilities-Public Service Board, written commun., 1983.) 


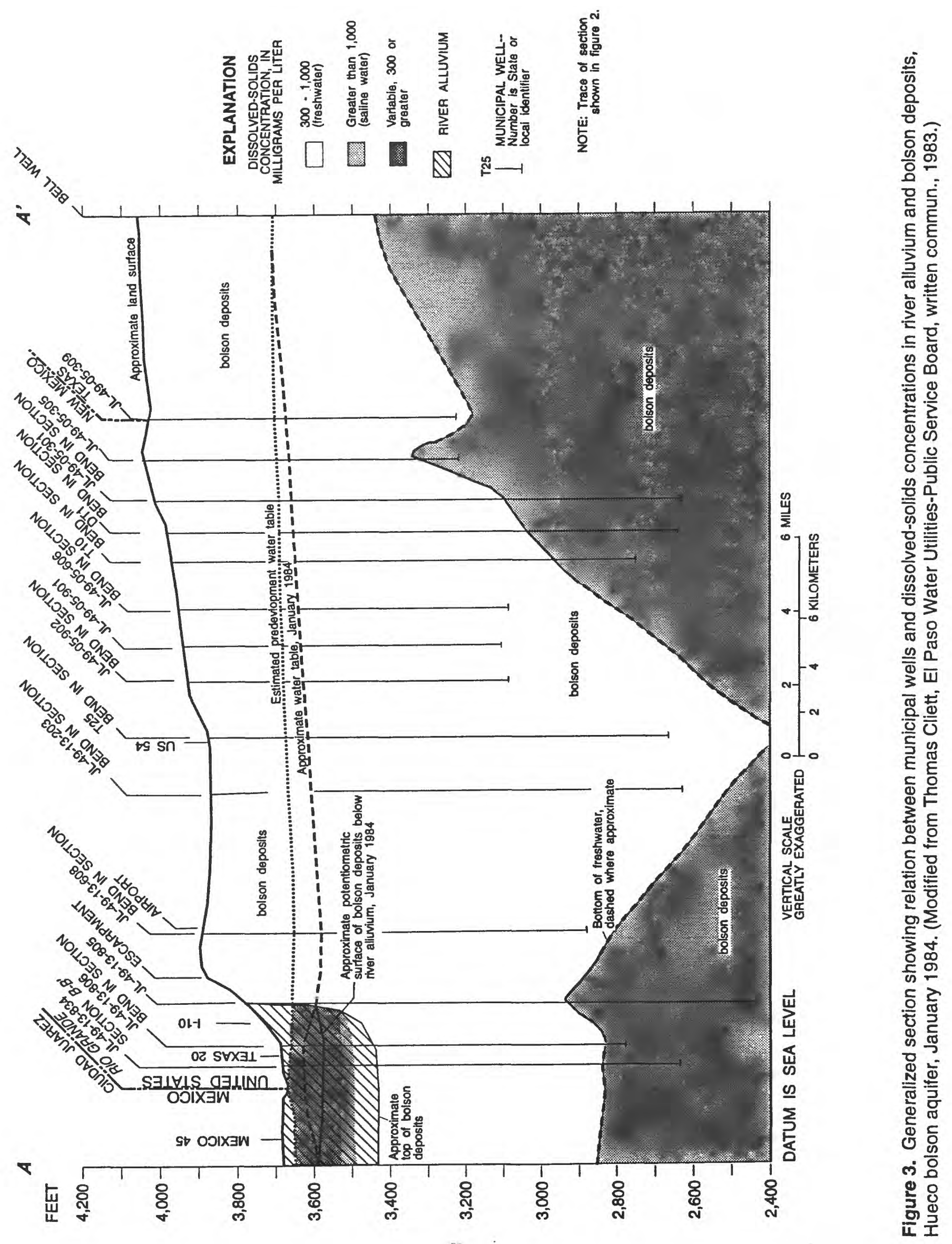


The water in the Rio Grande alluvium varies in salinity, caused in part by the complex hydrology of the area near the river. Drains, canals, and irrigation-return flow provide a source for water moving laterally or vertically into the alluvial aquifer. Irrigation, using surface water and shallow ground water, has been, and still is, intense in the Rio Grande alluvium. Irrigation-return flow has been the largest source of recharge to the alluvial aquifer during most of the historical period of development (1903-73) (Meyer, 1976). As the city of El Paso and Ciudad Juarez have expanded, the irrigated area has decreased steadily and is concentrated primarily in the southeastern part of the study area.

The complex hydrology of the river alluvium has changed considerably through time. After a 4.4-mi reach of the Rio Grande between El Paso and Ciudad Juarez was lined with concrete in 1968, streambed leakage from this reach was nearly eliminated. The water table in this area has declined about $50 \mathrm{ft}$ since the lining was installed, whereas the water table downstream from the lined reach has declined less than $10 \mathrm{ft}$ (White, 1983). A generalized section $\left(B-B^{\prime}\right)$ (figs. 2,4 ) shows the relation between water from municipal wells and freshwater and saline water in the river alluvium and the bolson deposits along the Rio Grande. The figure also shows the January 1984 water table in the Hueco Bolson aquifer and potentiometric surface in the bolson sediments underlying the Rio Grande alluvium.

\section{Purpose and Scope}

The purpose of this report is to describe the movement of saline water into the freshwater zone of the aquifer and thereby assess the potential for aquifer contamination by saline water as a result of continued and increased ground-water withdrawals. The principal method of analysis used to understand the movement of saline water into the aquifer was computer simulation of flow and solute transport. The report includes information on sources of saline-water intrusion and rates of movement under past (prior to 1984) and projected (1984-2000) ground-water withdrawals. Discussion of other sources of potential aquifer contamination is beyond the scope of this report.

\section{Location of Study Area}

The study area consists of a large part of El Paso County, located in the far western part of Texas, and adjacent areas in New Mexico and Mexico (fig. 1). The study area is in the Hueco bolson in the southern part of the Basin and Range physiographic province (Fenneman, 1931). The Franklin Mountains form the boundary to the west; the Hueco Mountains border the bolson to the east. The Hueco bolson extends north into New Mexico, where it is called the Tularosa Basin, and partly into Mexico, where the Sierra de Juarez and other mountains form a boundary.

The city of El Paso is located on the west side of the bolson. The downtown area overlies the Rio Grande alluvium; the city also includes the south end of the Franklin Mountains and areas on the mesa just east of the Franklin Mountains. Fort Bliss, a U.S. Army base, occupies large parts of the mesa area northeast of the city.

\section{Previous Investigations}

Many studies and published reports have described the water resources of the El Paso-Ciudad Juarez area. Slichter (1905) studied underflow and saline-water movement in the riverbed between the Franklin Mountains and the Sierra de Juarez. The report also described the relation between the bolson water table and the water table in the river alluvium. Richardson (1909) authored a geologic atlas, and Lippincott (1921) made an engineering study of the ground-water-supply system of El Paso. The geology and water resources were studied in detail by Sayre and Livingston (1945), Knowles and Kennedy (1958), and Leggat and others (1963). Leggat and Davis (1966) studied the hydrology and developed an electrical analog simulation of the Hueco bolson aquifer. Meyer and Gordon (1973) estimated the water budget for the Rio Grande alluvium. 


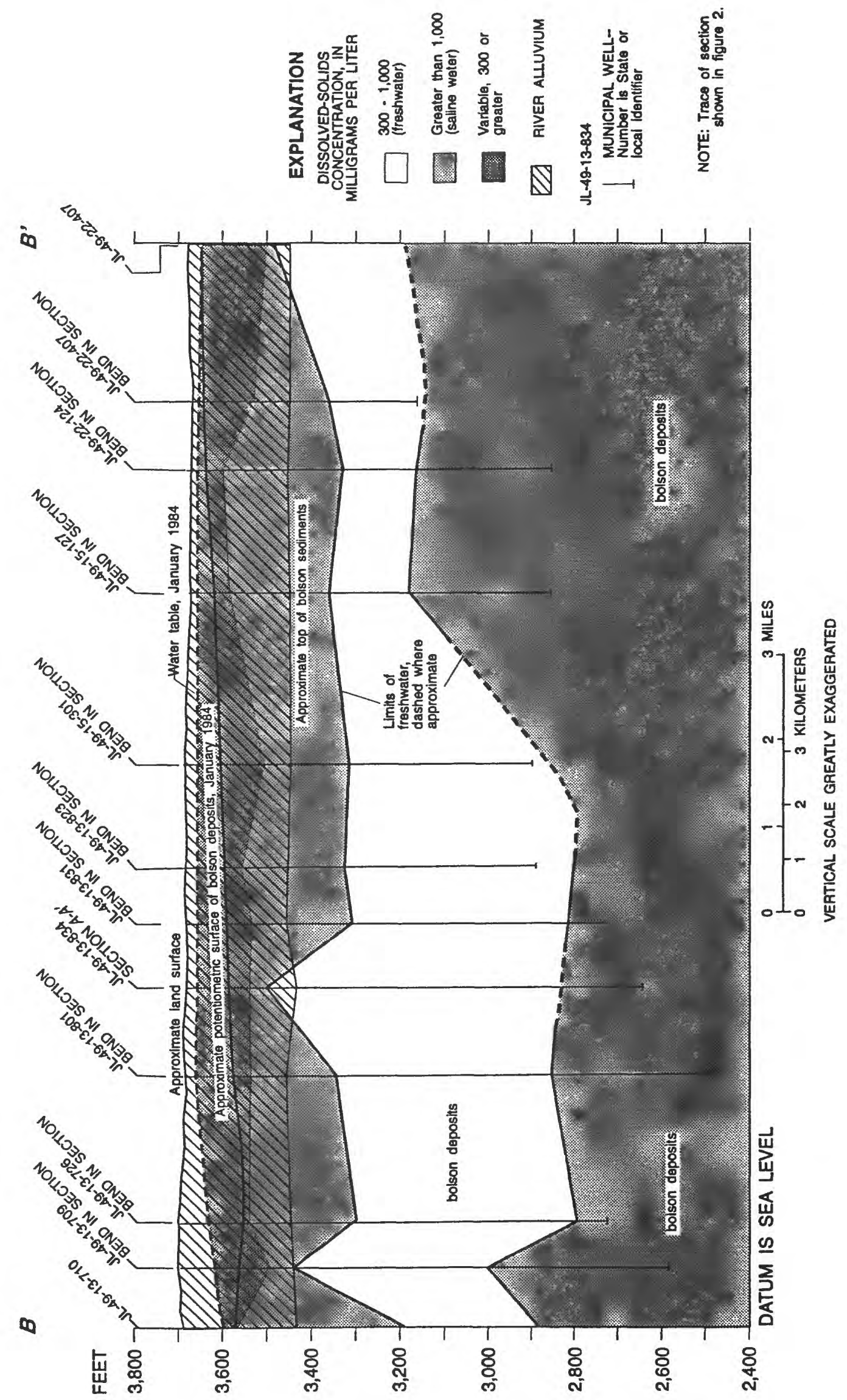

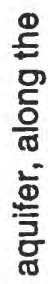

등 Ð

8

ํㅗ

$\Phi$

드

응 흔

뜬

잉

요

응

ㅎํㅇ 음

믕

里

등

品

증 웅

을 뭄

วิ

동

$\Phi$

范

드 등

定

흔 등

믿ㄴ

은

돈

过

음

놇 중

동

ऽ

+

닌

흔 음 
Recent reports on specific aspects of the ground-water resources include: Meyer and Gordon (1972); U.S. Bureau of Reclamation (1973); Bluntzer (1975); Gates and others (1978); and Alvarez and Buckner (1980). Ground-water flow-simulation studies of the effect of pumping on water levels were done by Meyer (1976) and Knowles and Alvarez (1979). Garza and others (1980) studied the potential for injection-well recharge using treated sewage effluent. Lee Wilson and Associates, Inc. (1981) studied El Paso's water supply, projected water demand, and potential supplies to 2080 , and proposed alternatives for alleviating potential shortages.

\section{Approach}

The overall approach to the study described in this report involved the analysis of the ground-water-flow system in the El Paso area by numerically simulating the movement of saline water in the Hueco bolson aquifer. The study was conducted in four phases. The first of these was the compilation of all data from historical reports and from investigations conducted during 1973-83. In the second phase of the study, a computer program developed by McDonald and Harbaugh (1988)--hereafter called the modular model--was used to simulate the flow of ground water during predevelopment conditions (before 1903) and during ground-water development (1903-83). Values for unknown or uncertain aquifer properties or conditions were adjusted to yield simulated results for 1903-72 that were similar to the aquifer properties simulated by Meyer (1976). In the third phase of the study, the response of the aquifer to estimated water withdrawals for 1984-2000 was simulated. In the final phase of the study, the movement of saline water was simulated using the results of the modular simulation in a heat- and solute-transport threedimensional (HST3D) flow model, developed by Kipp (1987), that simulates fresh and saline ground-water flow. The HST3D model was used to simulate regional salinity changes prior to 1984 and estimated withdrawals for 1984-2000.

The city of El Paso has injected treated sewage effluent into the aquifer during 1985-89 at an annual average rate of 2.65 to $4.38 \mathrm{Mgal} / \mathrm{d}$ (White and Sladek, 1990, p. 4) and plans to inject as much as $7.5 \mathrm{Mgal} / \mathrm{d}$ in the future (Lee Wilson and Associates, Inc., 1991). The simulations in this study included the water from an artificialrecharge project as a source to the aquifer. The leakage from existing oxidation lagoons of the sewage-treatment plant, located northeast of El Paso, also is included in the simulations. Leakage into the aquifer from the oxidation lagoons has formed a water-table mound underneath the lagoons (White, 1983, fig. 30).

Starting with the simplest simulation of the ground-water flow system using the modular model, densityrelated flow was added after the basic flow system was understood. Use of both models helped verify the flow results. The flow results simulated by the HST3D model were verified with the reliable and well-documented modular model. The need for simulation in three dimensions was based on the three-dimensional distribution of saline water underlying and overlying freshwater in places, and because upconing of saline water might be occurring.

Because vertical movement of saline water was assumed, the aquifer was divided into four layers to calculate vertical dissolved-solids concentration gradients.

A detailed study of the interaction of the large-capacity wells with each other and with the saline water was considered necessary because upconing of saline water was suspected, and because the regional flow-system simulation probably would not have sufficient detail to show upconing or the lack of upconing. Furthermore, a detailed study of the flow of freshwater and possibly saline water into wells would increase understanding of how anisotropic flow systems might affect the salinity of water produced from a well with a large screened interval. This part of the study was based on the HST3D model to consider a large block of hypothetical aquifer material (approximately 330 by $82 \mathrm{ft}$ and $330 \mathrm{ft}$ deep) with various well configurations and ranges of aquifer and fluid properties.

Finally, as a result of the series of simulations and adjustments to values of aquifer properties, a qualitative estimate of the reliability of the simulations of the aquifer and well withdrawals was developed. Sensitivity tests of the effect of various uncertainties in aquifer properties and conditions and characteristics of the HST3D model were conducted to estimate the reliability of the simulation results. 


\section{Acknowledgments}

Thomas Cliett, El Paso Water Utilities-Public Service Board, provided most of the information on well construction and plotted geophysical logs of water salinity. Roger Sperka, also of El Paso Water Utilities-Public Service Board, provided computer files of water use for the city of El Paso and Ciudad Juarez.

\section{GEOHYDROLOGIC SYSTEM}

Most of the following description of the geology and hydrology of the Hueco bolson is condensed from Leggat (1962) and White (1983). Readers who would like more specific information about the ground-water geology in the Hueco bolson are referred to those reports.

\section{Geology}

The Hueco bolson aquifer consists of upper Pliocene and lower Pleistocene coalescing alluvial fans and fluvial deposits of the ancestral Rio Grande. These deposits are part of the Santa Fe Group, and they consist of layers of clay, silt, sand, and gravel. The individual layers are poorly sorted and are as much as $100 \mathrm{ft}$ thick. Electric logs indicate that the individual lenses of clay, silt, sand, and gravel are not extensive and pinch out or grade into finer or coarser deposits laterally and vertically within short distances.

In general, individual sand lenses are thickest near the eastern side of the Franklin Mountains and the Sierra de Juarez; they become thinner and more fine-grained to the east. Throughout most of the study area, the deposits are not cemented, except where discontinuous caliche is present deep in the subsurface and in the soil zone where caliche forms an extensive, hard layer. The soil is relatively less cemented where caliche is absent near the eastern side of the Franklin Mountains and where the Rio Grande has entrenched the bolson deposits. The river alluvium underlying the present (1984) course of the Rio Grande is primarily reworked sediments (about 200 to $250 \mathrm{ft}$ thick) eroded from the bolson deposits. The distribution of silt and sand lenses in the river alluvium is similar to the distribution of silt and sand lenses in the bolson deposits.

\section{Ground-Water Flow System}

In this report, the Rio Grande alluvium is considered part of the Hueco bolson aquifer rather than a separate aquifer as it was in previous reports by Meyer and Gordon (1972), Meyer (1976), and Alvarez and Buckner (1980). Data to indicate that the river alluvium and bolson deposits are distinct aquifers do not exist. In this report, "Hueco bolson aquifer" includes Rio Grande alluvium and bolson deposits.

Under predevelopment conditions, water in the Hueco bolson aquifer was unconfined, and flow was generally to the south and southeast in the United States and to the east in Mexico. The estimated predevelopment water-table altitude is shown in figure 5. Recharge to the aquifer occurs along the western edge of the study area at the base of the Franklin Mountains and the Sierra de Juarez. Recharge, as defined by Meyer (1976), included a large component that is actually underflow from the north. Meyer (1976) estimated total annual recharge along the western and northem boundaries of the study area to be about 5,640 acre- $\mathrm{ft}$ for both predevelopment and developed conditions. The recharge rate was the result of calibrating a quasi-three-dimensional flow simulation using several simplifying assumptions.

Under predevelopment and historical development conditions, the Rio Grande was a discharge point for the entire Hueco bolson aquifer and a source of recharge. Discharge from the river alluvium prior to development was mostly by evapotranspiration. Before ground-water development, evapotranspiration from the alluvium was approximately balanced by seepage into the alluvium from the river and inflow from the Hueco bolson aquifer. After reservoirs were constructed along the Rio Grande to attenuate floods and hold water for irrigation, the flow of the river 


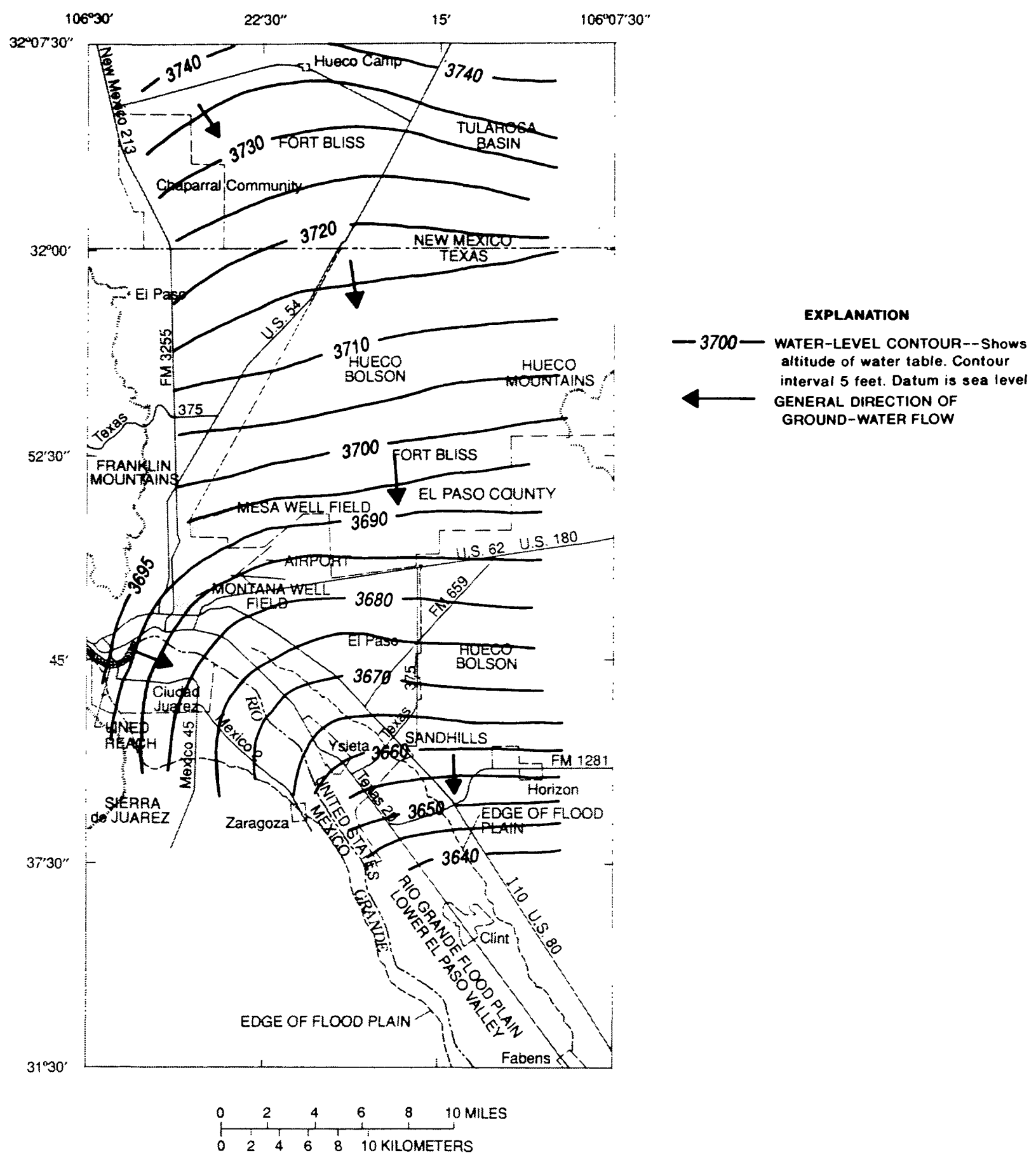

Figure 5. Estimated predevelopment water-table altitude, Hueco bolson aquifer. (Modified from White, 1983.) 
became much more stable. Recharge from the river-derived irrigation water, used to leach salts from the soil, caused the water table to rise enough to flood basements of buildings in El Paso (Sayre and Livingston, 1945).

After about 1940, water was pumped from deep in the bolson deposits to irrigate agricultural fields on the river alluvium. This tended to decrease the natural flow of water from the bolson deposits to the alluvium. The water level in the alluvium became more stable because of the application of water from the river and the installation of drains. Drains were installed to help prevent the increase of salt and to prevent water-logging of the soil. Although the alluvium has had large quantities of water flowing through it since about 1950, the water table has not fluctuated substantially and, disregarding seasonal fluctuations, does not fluctuate substantially where irrigation is still intensive. Meyer and Gordon (1972) concluded that flow in the drains is rejected recharge because the alluvium cannot accept more recharge when the water table is above the level of the drains. The steady-state condition of the water table in the river alluvium is limited to that part of the study area that is still intensively irrigated and is downstream from the urban area.

The ground-water flow system in the area at, and immediately southeast of, downtown El Paso has been complicated by (1) withdrawals from wells that were used to draw the water table down to stop basement flooding, (2) the rectification and deepening of the river channel, (3) the installation of drains, and (4) the lining of the channel of the Rio Grande in 1968 and other channels in the 1970's. The lining of the Rio Grande channel is important because it markedly decreased recharge to the river alluvium in the area. Some recharge to the alluvium from canals and runoff from the nearby Franklin Mountains and Sierra de Juarez still occurs, but the amount is relatively small.

Because the hydrology of the Rio Grande alluvium is complex, numerous data are required to simulate accurately ground-water flow in the alluvium. Much of the needed data do not exist, and existing data are of uncertain quality. Therefore, individual components of the water budget in the river area were not used in this report. Only net river leakage to the aquifer or net discharge to the river were estimated, on the basis of studies by Meyer and Gordon (1972) and Meyer (1976). Meyer and Gordon (1972) estimated the total annual water budgets of the river alluvium for 1968-71. Their study area, about $40 \mathrm{mi}$ long, included the river alluvium from near the city of El Paso southeast to the El Paso County line as well as the reach included in this study. The average estimated total amount of recharge to the alluvium was 81,000 acre-ft along the 40-mile river reach. The area of river alluvium for this report is only that part from the city of El Paso to a point about $18 \mathrm{mi}$ to the southeast; therefore, the amount of net leakage from the river should be less than half of the total estimated by Meyer and Gordon (1972), or less than 40,000 acre-ft if the recharge was distributed evenly along the whole section. The net rates of recharge and river leakage used by Meyer (1976) and those used in this report are listed in table 1.

The present (1984) flow system of the Hueco bolson aquifer is affected chiefly by large-capacity wells (table 1). These wells generally are screened through the entire thickness of the freshwater zone. The water-level altitude of the Hueco bolson aquifer in January 1984 is shown in figure 6. Estimated water-level changes from 1903 (fig. 5) to January 1984 are shown in figure 7. Large-capacity wells near the river in the city of El Paso are cased from land surface to below the saline water in the Rio Grande alluvium and are screened in the freshwater section beneath the saline water (fig. 4). Most other wells in the region have screens from the water table to the bottom of the freshwater zone (fig. 3). Recently, screens of new wells for the city of El Paso have been extended into the freshwater and the moderately saline water to increase the supply through mixing (Thomas Cliett, El Paso Water UtilitiesPublic Service Board, written commun., 1983). Water levels in the wells that are screened from the water table down represent an average head for the entire thickness of the screened interval and are not truly representative of the water table or the hydraulic head at a specific depth interval in the aquifer.

Because of the layering of deposits, the vertical permeability of the Hueco bolson aquifer is small compared to the horizontal permeability. On the scale of this study and the size of the cells used in the numerical simulation, the aquifer was treated as though it was homogeneous but with large differences between vertical and horizontal permeabilities. The ratio of horizontal to vertical permeability was assumed to range from about 10:1 to about 1,000:1 because of differences between the permeability of sand and the fine-grained silt and clay (Freeze and Cherry, 1979, p. 29). 


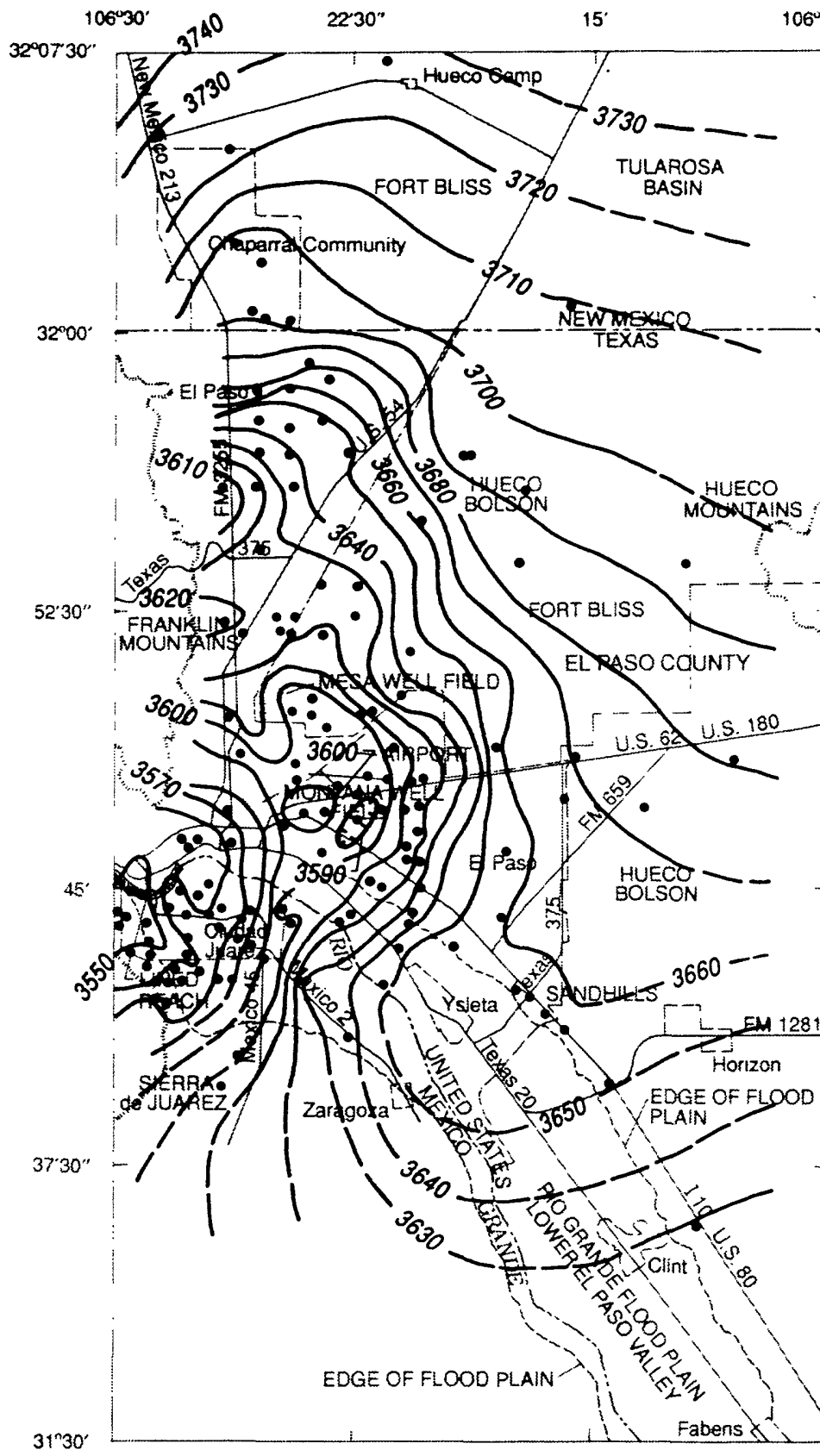

EXPLANATION

- 3700 - WATER-LEVEL CONTOUR--Shows altitude of water level. Dashed where approximately located. Hachures indicate depression. Contour interval 10 feet. Datum is sea level

- WELL USED FOR CONTOUR

Figure 6. Water-level altitude, Hueco bolson aquifer, January 1984. (Modified from Roger Sperka, El Paso Water Utilities-Public Service Board, written commun., 1985.) 


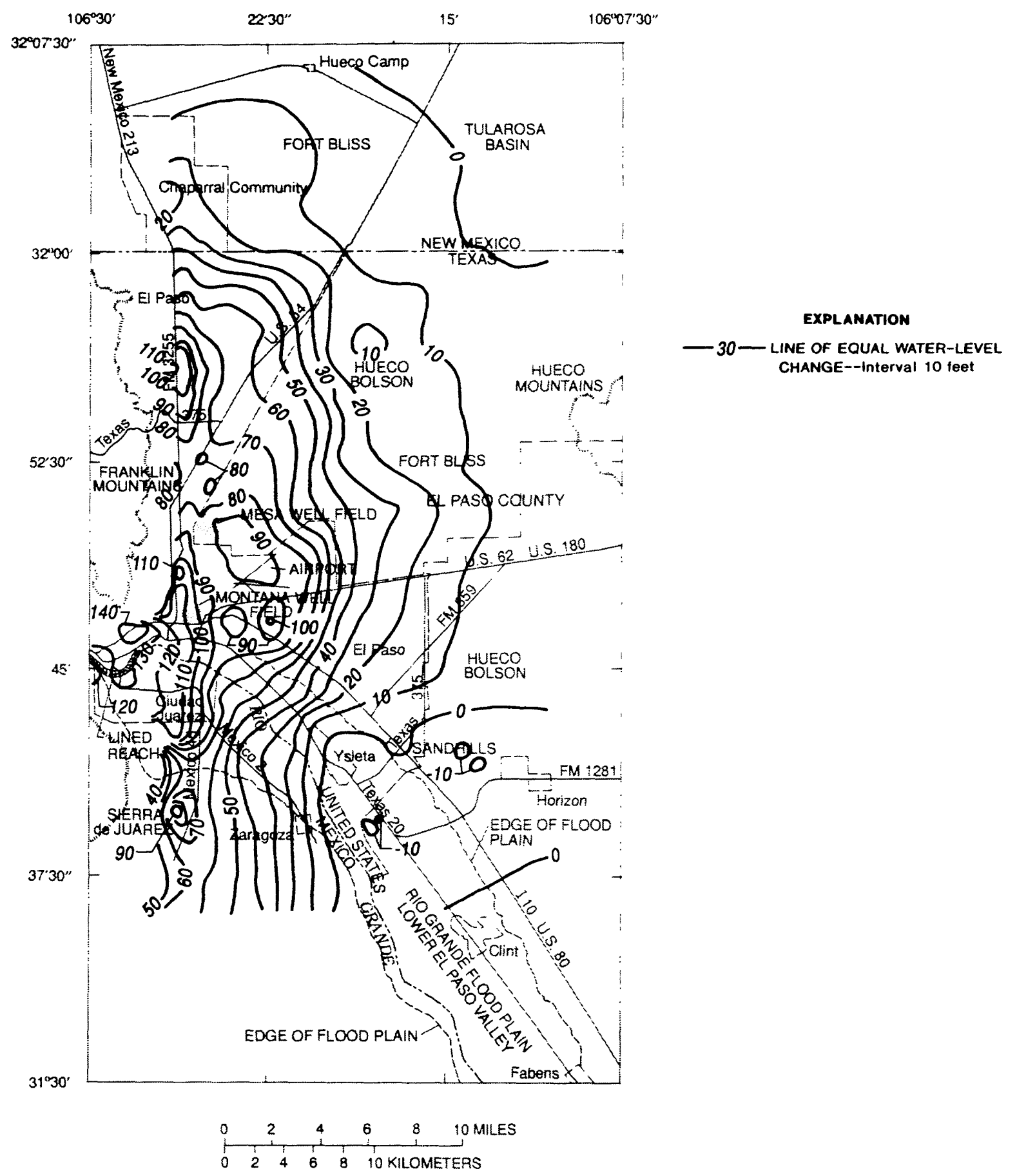

Figure 7. Estimated water-level changes, Hueco bolson aquifer, 1903-84. 
Table 1. Estimates of net recharge, underflow, river-leakage rates, and total well withdrawals of the Hueco bolson aquifer

[Values are reported in acre-feet. -, indicates discharge to river; +, indicates leakage into aquifer; --, does not apply]

\begin{tabular}{|c|c|c|c|c|c|c|}
\hline \multirow[b]{2}{*}{ Perlod } & \multirow{2}{*}{$\begin{array}{c}\text { Meyer (1976) } \\
\begin{array}{c}\text { Net recharge } \\
\text { and net } \\
\text { underflow }\end{array}\end{array}$} & \multicolumn{2}{|c|}{ This report } & \multirow{2}{*}{$\begin{array}{c}\text { Meyer (1976) } \\
\begin{array}{c}\text { Net river } \\
\text { leakage }\end{array}\end{array}$} & \multirow{2}{*}{$\begin{array}{c}\text { This report } \\
\begin{array}{c}\text { Net river } \\
\text { leakage }\end{array}\end{array}$} & \multirow{2}{*}{$\begin{array}{c}\text { This report } \\
\begin{array}{c}\text { Total well } \\
\text { withdrawals }\end{array}\end{array}$} \\
\hline & & $\begin{array}{c}\text { Net } \\
\text { recharge }\end{array}$ & $\begin{array}{c}\text { Net } \\
\text { underflow }\end{array}$ & & & \\
\hline Predevelopment & 5,640 & 2,200 & 4,300 & ${ }^{1}-5,640$ & $-6,500$ & 0 \\
\hline $1903-20$ & 5,640 & 2,200 & 8,200 & $-6,864$ & $-6,000$ & ${ }^{2} 350$ \\
\hline $1920-36$ & 5,640 & 2,200 & 7,800 & -353 & $-1,400$ & ${ }^{2} 13,000$ \\
\hline $1936-48$ & 5,640 & 2,200 & 7,700 & $+4,588$ & $+1,100$ & ${ }^{2} 21,000$ \\
\hline $1948-53$ & 5,640 & 2,200 & 7,800 & $+7,625$ & $+3,000$ & ${ }^{2} 30,000$ \\
\hline $1953-58$ & 5,640 & 2,200 & 8,100 & $+13,466$ & $+12,000$ & ${ }^{2} 54,000$ \\
\hline $1958-63$ & 5,640 & 2,200 & 8,600 & $+18,767$ & $+12,000$ & ${ }^{2} 63,000$ \\
\hline $1963-68$ & 5,640 & ${ }^{3} 6,700$ & 9,200 & $+19,183$ & $+11,000$ & 275,000 \\
\hline $1968-73$ & 5,640 & 6,700 & 9,400 & $+12,765$ & $+11,000$ & ${ }^{2} 90,000$ \\
\hline 1973 & 5,640 & 6,700 & 9,500 & $+21,075$ & $+11,000$ & ${ }^{4} 114,000$ \\
\hline 1974 & 5,640 & 6,700 & 9,600 & $+21,075$ & $+12,000$ & ${ }^{4} 115,000$ \\
\hline 1975 & 5,640 & 6,700 & 9,700 & $+21,075$ & $+12,000$ & ${ }^{4} 114,000$ \\
\hline 1976 & 5,640 & 6,700 & 9,800 & $+21,075$ & $+12,000$ & ${ }^{4} 115,000$ \\
\hline 1977 & 5,640 & 6,700 & 10,000 & $+21,075$ & $+13,000$ & ${ }^{4} 126,000$ \\
\hline 1978 & 5,640 & 6,700 & 10,000 & $+21,075$ & $+14,000$ & ${ }^{4} 132,000$ \\
\hline 1979 & 5,640 & 6,700 & 10,000 & $+21,075$ & $+14,000$ & ${ }^{4} 130,000$ \\
\hline 1980 & 5,640 & 6,700 & 10,000 & $+21,075$ & $+14,000$ & ${ }^{4} 130,000$ \\
\hline 1981 & 5,640 & 6,700 & 11,000 & $+21,075$ & $+15,000$ & ${ }^{4} 134,000$ \\
\hline 1982 & 5,640 & 6,700 & 11,000 & $+21,075$ & $+15,000$ & ${ }^{4} 148,000$ \\
\hline 1983 & 5,640 & 6,700 & 11,000 & $+21,075$ & $+16,000$ & ${ }^{4} 145,000$ \\
\hline $1984-85$ & 5,640 & 6,700 & 11,000 & $+21,075$ & $+16,000$ & $5_{156,000} \quad 147,000$ \\
\hline $1985-90$ & 5,640 & 6,700 & 12,000 & $+21,075$ & $+16,000$ & ${ }^{5} 170,000 \quad 147,000$ \\
\hline $1990-95$ & 5,640 & 6,700 & 13,000 & $+21,075$ & $+16,000$ & $5_{214,000} \quad 182,000$ \\
\hline $1995-2000$ & 5,640 & 6,700 & 14,000 & -- & $+16,000$ & $5_{231,000} \quad 195,000$ \\
\hline
\end{tabular}

${ }^{1}$ Steady-state budget is not given in Meyer (1976), discharge is assumed to be equal to the net recharge plus underflow value.

${ }^{2}$ Well withdrawals for both studies are equal for 1903-73.

${ }^{3}$ In this study, recharge after 1962 includes seepage from oxidation lagoons.

4 Withdrawals listed for 1973-83 are measured withdrawals.

${ }^{5}$ Larger and smaller estimates were used in simulations of projected aquifer conditions. 
The anisotropy of the Hueco bolson aquifer causes the lower two-thirds of the aquifer to react to pumping as a semiconfined or confined aquifer under short-term, unsteady conditions. Therefore, for a short time after pumping starts, there is a larger decline in water levels in this part of the aquifer for a given withdrawal than there is for the unconfined upper one-third of the aquifer. After a sufficient duration of pumping, a downward vertical gradient develops from the water table to the deeper sections of the aquifer. Because of the large volumes of water withdrawn in the study area, this downward gradient persists for some time after pumping ceases. When a well is not pumped, water will flow into the upper screened sections and out of the deeper screened sections of the well. This tends to decrease the vertical head gradient. If the vertical gradient develops while a well with a long screen is being pumped, flow into the well screen will decrease at depth and increase near the water table in the upper sections of the screened interval.

Water levels in wells that are screened only in the freshwater zone beneath the river alluvium are a composite head for a short, but deep section of the Hueco bolson aquifer. The water levels in these wells are indicative of the head in the deeper semiconfined interval of the aquifer, although they are still depth-averaged to some extent. Less chance exists for a decrease in vertical head difference between the water table and the deeper sections of the aquifer when the wells are not pumping because the screen does not intersect the water table.

The screened intervals for wells distant from the river commonly intersect the water table, and those for wells near the river generally do not. Therefore, a longer lag time exists between development of a downward gradient from the water table into the lower two-thirds of the aquifer near the river than exists distant from the river. This lag time might be longer than the time between periods of pumping. Thus, the water-level contours shown in figure 6 are more representative of the head in the semiconfined lower part of the aquifer than of the water table in the upper part of the aquifer in the river alluvium.

Water levels in some shallow wells completed in the alluvium indicate that the water table is 50 to $60 \mathrm{ft}$ higher than water levels in the deep wells (Land and Armstrong, 1985). Land and Armstrong (1985) also indicate that the river alluvium between the land surface and the regional water table in the area where the Rio Grande is lined is partially saturated and might contain a perched water table. The overall effect of the withdrawals from deep wells in the vicinity of the unlined river reach is to induce substantial recharge from irrigation return flow, the canals and diversions, and the river.

The Franklin Mountains, Hueco Mountains, Sierra de Juarez, and other mountains to the south are considered almost impermeable boundaries to ground-water flow. They consist of igneous and metamorphic rocks and limestone. Some wells have been completed in these rocks, but they yield only small quantities of saline water.

\section{Salinity}

White (1983) presents a detailed overview of the natural water quality in the El Paso area and the changes that have occurred since ground-water development began. Most of the following discussion is condensed from his report. Dissolved-solids concentrations in water sampled from the Hueco bolson aquifer range from less than 300 $\mathrm{mg} / \mathrm{L}$ in the bolson deposits underlying the mesa area to about $30,000 \mathrm{mg} / \mathrm{L}$ in the deep, fine-grained clay and silt. Most freshwater is contained in the coarsest sand lenses along and parallel to the east side of the Franklin Mountains. This freshwater zone extends northward into New Mexico, where it becomes narrower and thinner. North of the study area in New Mexico, the freshwater zone becomes thicker and wider again.

East of the zone of freshwater, the water generally is saline with small areas containing slightly saline water or freshwater. The low permeability of these sediments with relatively fewer sand lenses and more fine-grained clay and silt and negligible recharge probably contribute to the slow movement of the water and the resulting greater salinity in this area.

The salinity of the water in the river alluvium is variable. At the water table, there is a thin layer of deposits containing freshwater to slightly saline water in the upper $50 \mathrm{ft}$ of the aquifer. Between 50 and 200 to $250 \mathrm{ft}$, there is a zone of slightly saline water. Below this zone of slightly saline water in the area near El Paso and for about $10 \mathrm{mi}$ 
downriver, there is a 300- to 400-ft thick layer of deposits containing freshwater. Farther downriver, the water is all slightly to moderately saline. Below the freshwater layer, the water is slightly saline to very saline. The presence of saline water in the river alluvium is assumed to be a natural phenomenon and can be explained in part by three factors:

1. The alluvium is the endpoint of long ground-water flowpaths; the length of the flowpath of water in the aquifer is a primary factor affecting the concentration and relative proportions of dissolved minerals in the water. The river alluvium near El Paso and Ciudad Juarez receives discharge from the freshwater section of the bolson deposits under natural conditions. The alluvium downstream, from about $10 \mathrm{mi}$ southeast of El Paso and farther to the southeast, receives slightly saline to moderately saline water that is discharged from most of the bolson deposits, also under natural conditions.

2. Evapotranspiration is the major component of ground-water discharge in the area where the water table is near land surface. Evaporation increases the salinity of the water remaining in the soil and increases soluble salts in the unsaturated zone, which in turn are leached into the saturated zone during major rainstorms or floods and during periods of irrigation.

3. Slichter (1905) studied the flow of ground water in the river alluvium between the Franklin Mountains and Sierra de Juarez. He reported that the river alluvium contained slightly to very saline water that moves relatively slowly. The saline water in the alluvium results either from upward leakage of saline water from the underlying bedrock or by evapotranspiration from the water table or a combination of these two factors. The fact that the river was not perennial prior to development in this area is further evidence that the saline water in the river alluvium downstream from these mountains also could have been the result of evapotranspiration.

Data collected by White (1983) relating to the distribution of salinity in the Hueco bolson, data from electric logs collected by Knowles and Kennedy (1958), and data collected during the continuing program of logging by the El Paso Water Utilities-Public Service Board were available to estimate the predevelopment distribution of salinity in the study area. Regional dissolved-solids concentrations, except near the river, probably did not change appreciably until 30 to 50 years ago, prior to the first electric logging by Knowles and Kennedy (1958). The predevelopment distribution of dissolved-solids concentrations in ground water is uncertain because the location and magnitude of changes in dissolved-solids concentrations changes prior to 1958 are unknown, but these changes are considered insignificant with respect to changes that have occurred since 1958. Dissolved-solids concentrations in ground water in 1980 are shown in figure 8.

The areal distribution of salinity in the Hueco bolson aquifer is a two-dimensional representation of a threedimensional phenomenon; therefore, the true shape of the freshwater zone is not apparent. Generalized sections showing the third dimension of the salinity distribution are shown in figures 3 and 4 . Most wells in the study area are drilled into the freshwater zone, and some extend into the zone of slightly saline water. Most wells are not drilled far into zones where dissolved-solids concentrations exceed $1,000 \mathrm{mg} / \mathrm{L}$. The zone in which dissolved solids exceed $1,000 \mathrm{mg} / \mathrm{L}$ contains slightly saline to very saline water with dissolved-solids concentrations of as much as $30,000 \mathrm{mg} / \mathrm{L}$. Generally, the salinity increases with depth.

Small areas of freshwater in the eastern one-half of the aquifer are surrounded by slightly saline to moderately saline water (fig. 8). The exact three-dimensional shape of these freshwater areas and their origin are unknown. Generally, the freshwater to slightly saline water is at or near the water table and could be the result of recharge caused by large floods. The largest of these freshwater areas, near Fabens, is at the mouth of a large arroyo eroded into the mesa edge and indicates that recharge from the western side of the bolson could have been the source of the freshwater. The freshwater in the Fabens area is overlain by slightly saline to moderately saline water. If recharge from a large flood created this area of freshwater, the flood probably was not as recent as those that created the other freshwater areas that are near the water table.

The freshwater in an area along the eastem side of the Franklin Mountains (fig. 8) generally contains about 300 to $500 \mathrm{mg} / \mathrm{L}$ dissolved solids. The freshwater zone is widest at or near the water table, and the zone narrows 


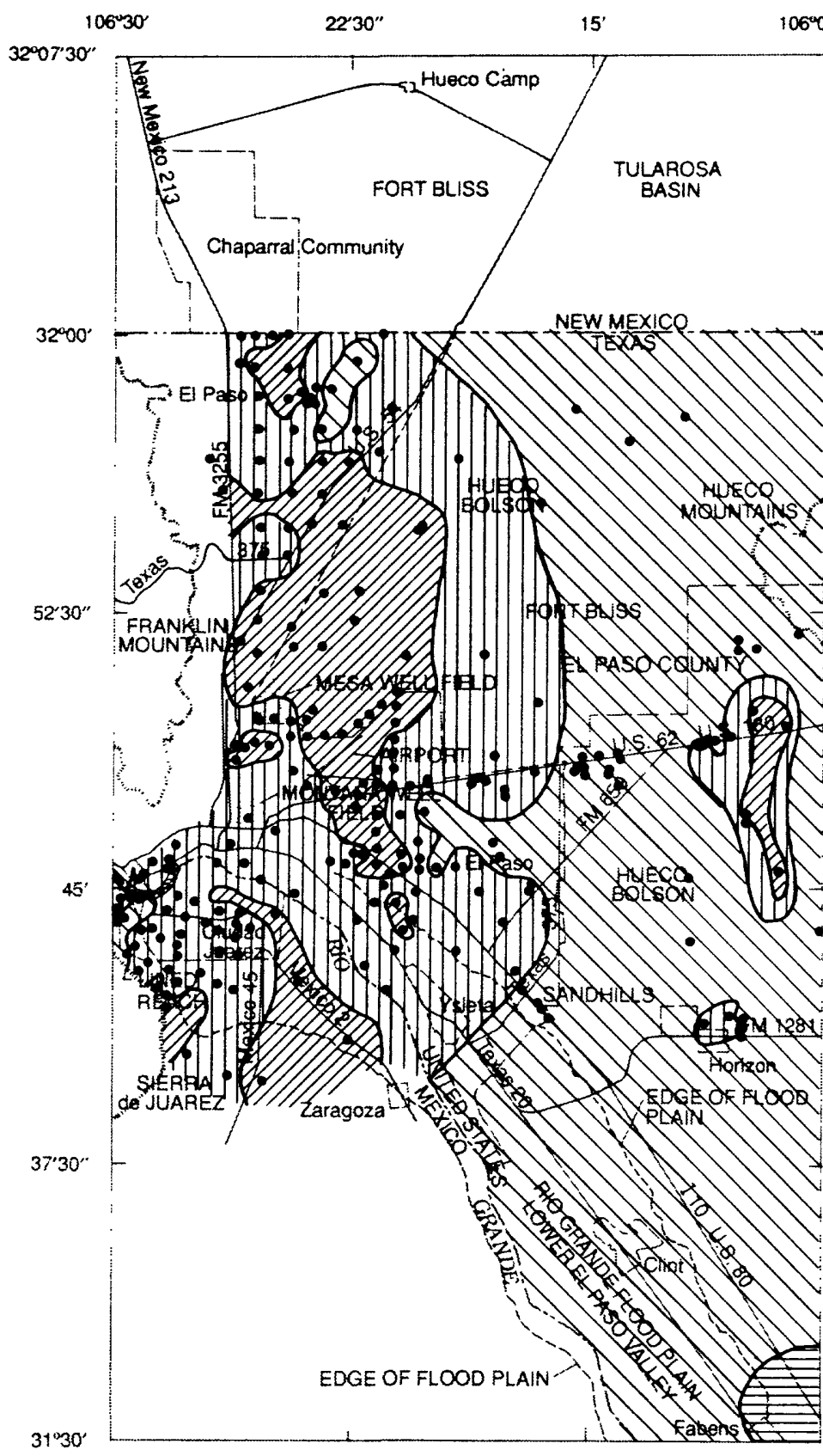

EXPLANATION

DISSOLVED-SOLIDS CONCENTRATION.

IN MILLIGRAMS PER LITER

DDT 0 to 500

गाD 501 to 1.000

Greater than 1.000

Variable. 501 to greater than 1.000 WELL USED FOR CONTROL

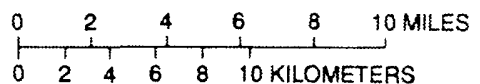

Figure 8. Areal distribution of dissolved-solids concentrations in the Hueco bolson aquifer, 1980. (Modified from White, 1983.) 
with depth. The deepest part of the freshwater zone is about midway between the Rio Grande and the Texas-New Mexico border (fig. 3). In this area, the freshwater zone is about 1,000 ft thick. Most of the freshwater with dissolved-solids concentrations ranging from 500 to $1,000 \mathrm{mg} / \mathrm{L}$ is located between 200 to $400 \mathrm{ft}$ below the water table. The "tongue" of slightly saline water near the El Paso airport (fig. 8) could reflect a natural condition but more likely is the result of movement of saline water to the wells located within the tongue.

The salinity of water from a number of wells in the Hueco bolson aquifer has increased with time. Average annual change in dissolved-solids concentrations, and areas where appreciable changes in dissolved-solids concentrations have occurred in wells from the earliest sample analysis to an analysis made during 1979-81, are described by White (1983). Not all of the changes are increases; decreases in dissolved-solids concentrations have occurred in some wells. The available data are insufficient to define whether the changes in salinity described by White (1983) are caused by upconing or lateral movement; nor can the depth of saline-water intrusion be identified. Irrigation return flow affects the entire Rio Grande alluvium area and could be causing salinity to increase in some parts of the Rio Grande alluvium. The amount and distribution of pumping by irrigation wells in the alluvium is complicated and not recorded in detail. The amount of water withdrawn is approximately balanced by water that seeps into the aquifer from irrigated areas and from the river.

Evaporation of applied irrigation water can increase the salinity of the water of the river alluvium although there are no unequivocal data to indicate that a regional increase in salinity of the water in the river alluvium has occurred. Meyer and Gordon (1972) state that dissolved-solids concentrations in drainflow (rejected recharge from irrigation) increase during the irrigation season. This increase indicates that even though the applied irrigation water might be more saline than the drainflow water during the rest of the year, most of it is diverted from reaching the water table by the drains.

Available data also indicate that saline water is moving downward and laterally in the Rio Grande alluvium and adjacent areas. Saline water also moves from the east towards centers of pumping to the west on the mesa area (D.E. White, U.S. Geological Survey, written commun., 1987). Available data indicate that water from the oldest wells, just northeast of El Paso, has increased in salinity from 1917 to the present (1984).

El Paso Water Utilities-Public Service Board recently replaced a supply well near the airport because of progressive salinity increases, which began in 1971. The replacement well was located about $125 \mathrm{ft}$ to the north-northwest of the original well. Upconing of saline water from beneath the freshwater zone tapped by the well was suspected as the cause of the increased salinity in the old well. The electric logs indicate that the source of saline water is near the water table and not at the bottom of the well (Thomas Cliett, El Paso Water Utilities-Public Service Board, written commun., 1986). This information is the only verifiable data (as of 1986) to indicate how wells in the Hueco bolson aquifer become contaminated with saline water. The actual means by which other wells become contaminated with saline water is unknown.

\section{Ground-Water Withdrawals}

\section{Historical}

The following summary of the history of ground-water development has been condensed from numerous published reports. The first ground-water development in the El Paso area was in 1892 when 30 wells were drilled near the Rio Grande for municipal supply. These wells were soon abandoned because they yielded saline water; however, one well was used for a supply of slightly saline water until 1904. In 1904, wells were drilled in the mesa area just northeast of El Paso. This area became known as the Mesa well field (fig. 1), and by 1917, the city had 44 wells in the area. Because of the deep water levels and the inefficiency of the wells (air-lift methods were used to pump the water), the costs became too great to continue using this well field. Beginning in 1917, wells were drilled near present downtown El Paso, in an area known as the Montana well field (fig. 1). By 1926, pumping at the Mesa well field had stopped temporarily, and the Montana well field was the main source of supply. 
From the early 1920 's through 1935 , the chloride concentration in the water from several wells in the Montana well field gradually increased (Sayre and Livingston, 1945, p. 49-50). In 1935, the introduction of efficient turbine pumps and subsequent large increases in the chloride concentration in water from wells in the Montana well field resulted in renewed development of the Mesa well field. From 1918 to 1943, the entire water supply for El Paso was pumped from these two well fields. In 1943, the city of El Paso and the U.S. Army began using water from the Rio Grande to supplement the ground-water supply.

From 1940 to 1950, the El Paso Valley Water District drilled wells beneath the river alluvium southeast of El Paso for the municipal supply for that area. After exploration of the northeastern part of the Hueco bolson aquifer in 1953-54, development was extended northward to within $2 \mathrm{mi}$ of the Texas-New Mexico border. The development of new wells continued, and by 1960, there were about 107 large-capacity wells, 72 of which were used for municipal supply (Leggat, 1962). By 1963, Ciudad Juarez had drilled 33 wells for municipal supply (Davis, 1965).

Ground-water-withdrawal data for Ciudad Juarez are collected by the Junta Municipal de Aguas y Saneamiento (JMAS). Ground-water-withdrawal data for the city of El Paso are reported by well field and stored by well number in the files of the El Paso Water Utilities-Public Service Board. Water-use data are collected by the El Paso Water Utilities-Public Service Board, the Texas Water Development Board, and the USGS. Withdrawals from the Hueco bolson aquifer for 1903-83 are shown in figure 9. Locations of wells pumped in 1983 are shown in figure 10 .

\section{Projected}

Although the process of predicting population increases and water use per capita is problematic and uncertain, these projections need to be made for planning purposes. Two estimates of ground-water withdrawals from the Texas part of the Hueco bolson aquifer are used in this study (Knowles and Alvarez, 1979; Lee Wilson and Associates, Inc., 1986, table 6:5-1). A recent study of water use and projected water use in Ciudad Juarez (R.A. Marston and W.J. Lloyd, University of Texas at El Paso, written commun., 1985) provided estimated ground-water withdrawals from the Mexico part of the bolson. The three estimates of ground-water withdrawals through 2004 are given in table 2 .

Knowles and Alvarez (1979) used the Texas Department of Water Resources estimates for population and per capita water consumption to project withdrawals to 2029 in the United States part of the Hueco bolson aquifer. Knowles and Alvarez (1979) also used these estimates with the simulation developed by Meyer (1976) to test the effect of the projected withdrawals on the Hueco bolson aquifer. The Texas Department of Water Resources projections of water use are larger than those made by the El Paso Water Utilities-Public Service Board. The Texas Department of Water Resources projections also are larger than those used by Meyer (1976). Recent data (D.E. White, U.S. Geological Survey, written commun., 1985) indicate that the Texas Department of Water Resources estimates have closely approximated the actual amount of ground water withdrawn to 1985 and are used in this report to represent the larger of the two expected water-use projections in the Texas part of the study area.

Lee Wilson and Associates, Inc. (1986) made detailed population and per capita water consumption estimates to develop ground-water-withdrawal projections through 2050. Those estimates of future withdrawals represent the smaller of the two projections used in this study for the Texas part of the Hueco bolson aquifer (see table 2). As used in this report (table 2), the larger estimate of projected ground-water withdrawals is defined as the sum of the Texas Water Development Board (Knowles and Alvarez, 1979) estimates for projected Texas (United States) withdrawals and the projected withdrawals in Ciudad Juarez (Mexico) estimated by R.A. Marston and W.J. Lloyd (University of Texas at El Paso, written commun., 1985). The smaller estimate of projected withdrawals is defined as the sum of the projected Texas (United States) withdrawals estimated by Lee Wilson and Associates, Inc. (1986) and the projected withdrawals in Ciudad Juarez (Mexico) estimated by R.A. Marston and W.J. Lloyd (University of Texas at El Paso, written commun., 1985). 


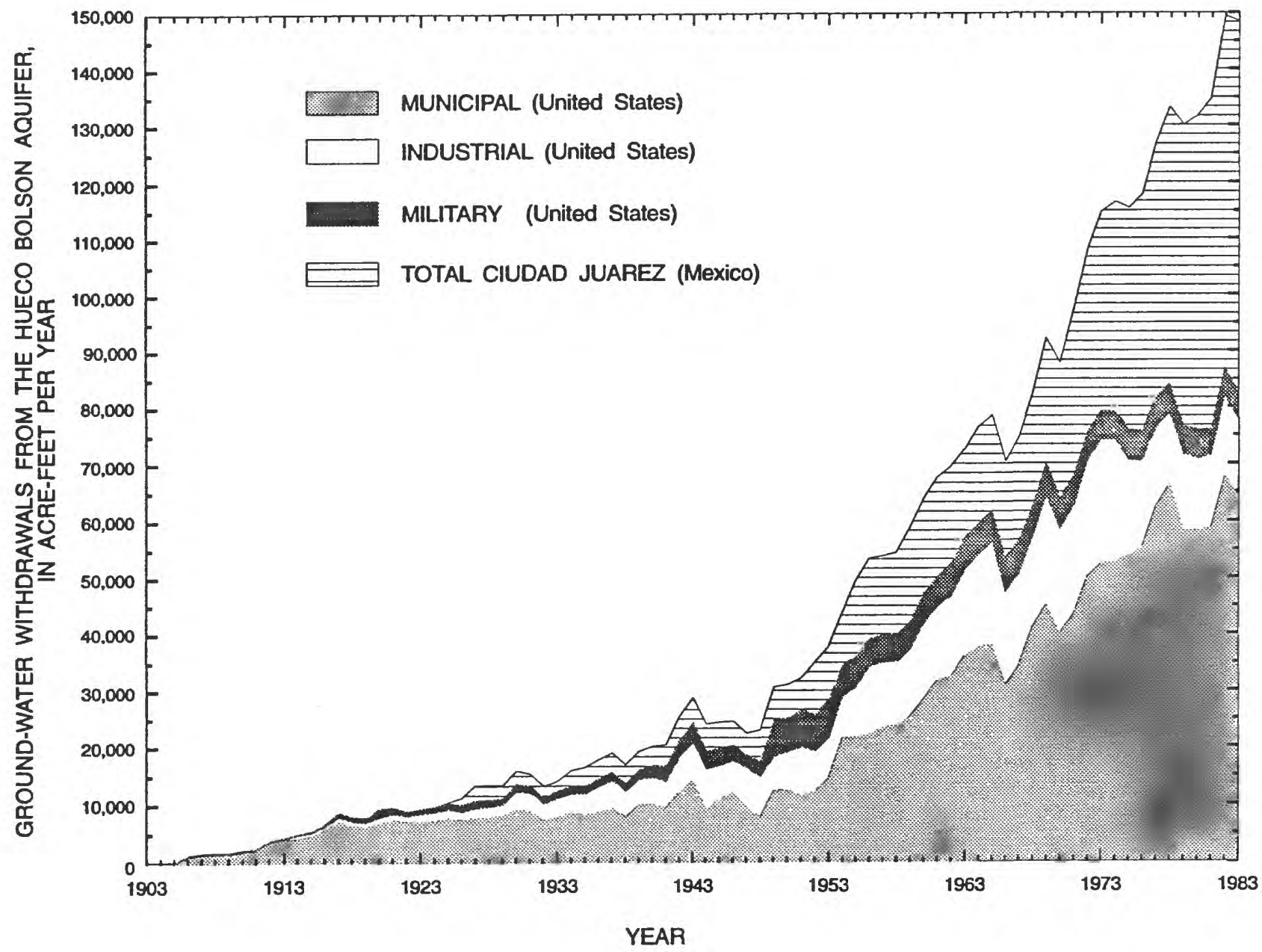

Figure 9. Withdrawals from the Hueco bolson aquifer in the El Paso-Ciudad Juarez area, 1903-83. 


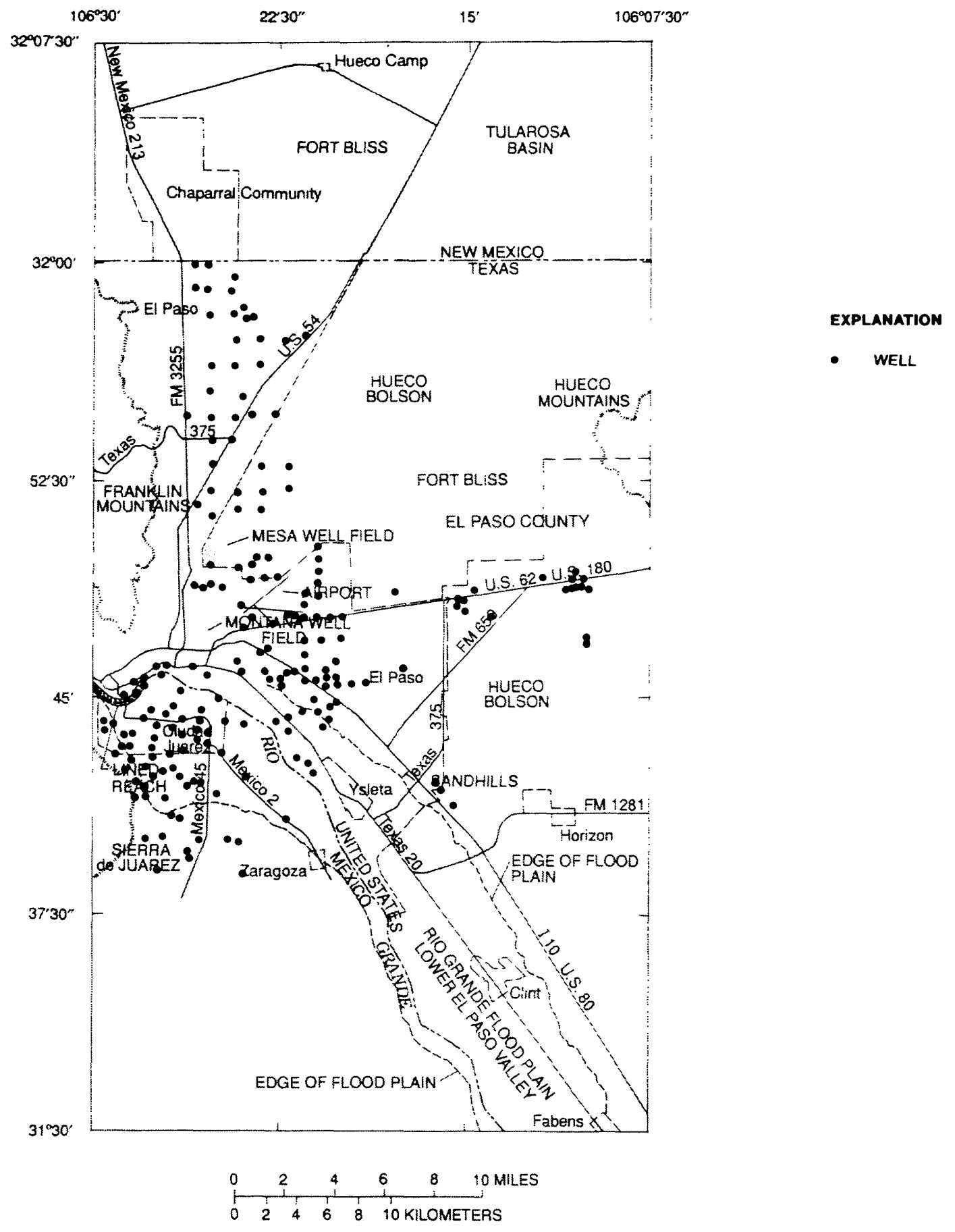

Figure 10. Location of wells pumped from the Hueco bolson aquifer in the El Paso-Ciudad Juarez area, 1983. (Modified from White, 1983.) 
Table 2. Estimates of ground-water withdrawal rates used for water-use projections [acre-ft/yr, acre-foot per year]

\begin{tabular}{|c|c|c|c|c|c|}
\hline \multirow{2}{*}{ Agency or author } & \multicolumn{5}{|c|}{$\begin{array}{l}\text { Estimated ground-water withdrawal rates } \\
\text { (acre-ft/yr) }\end{array}$} \\
\hline & 1984 & $1985-89$ & $1990-94$ & 1995-99 & 2000-04 \\
\hline $\begin{array}{l}\text { Texas Department of Water Resources } \\
\text { (Knowles and Alvarez, 1979) }\end{array}$ & 92,500 & 109,000 & 129,000 & 149,000 & 175,000 \\
\hline $\begin{array}{l}\text { Lee Wilson and Associates, Inc. } \\
(1986, \text { table } 6: 5-1)^{1}\end{array}$ & 83,000 & 83,000 & 92,500 & 107,000 & 120,000 \\
\hline $\begin{array}{l}\text { R.A. Marston and W.J. Lloyd (University of } \\
\text { Texas at El Paso, written commun., 1985) }\end{array}$ & 67,900 & 67,900 & 91,600 & 91,600 & 128,000 \\
\hline \multicolumn{6}{|l|}{ TOTALS } \\
\hline Larger estimate of projected withdrawals ${ }^{3}$ & 160,000 & 177,000 & 221,000 & 241,000 & 303,000 \\
\hline Smaller estimates of projected withdrawals ${ }^{4}$ & 151,000 & 151,000 & 184,000 & 199,000 & 248,000 \\
\hline
\end{tabular}

${ }^{1}$ For Texas (United States) only.

${ }^{2}$ For Ciudad Juarez (Mexico) only.

${ }^{3}$ For Texas (United States), Knowles and Alvarez (1979); for Ciudad Juarez (Mexico), R.A. Marston and W.J. Lloyd (University of Texas at E1 Paso, written commun., 1985).

${ }^{4}$ For Texas (United States), Lee Wilson and Associates, Inc. (1986); for Ciudad Juarez (Mexico), R.A. Marston and W.J. Lloyd (University of Texas at El Paso, written commun., 1985).

\section{SIMULATION OF GROUND-WATER FLOW AND SOLUTE TRANSPORT}

\section{General Description of Modular Model}

In the second and third phases of the study, the three-dimensional modular model developed by McDonald and Harbaugh (1988) was used to simulate the ground-water flow in the Hueco bolson aquifer under predevelopment (before 1903) and historical pumping conditions (1903-83). The following section describes the mathematical basis for this modular model.

The three-dimensional movement of ground water of constant density through a porous medium can be described by the partial-differential equation (McDonald and Harbaugh, 1988, p. 7, equation 1):

$$
\frac{\partial}{\partial x}\left(K_{x x} \frac{\partial h}{\partial x}\right)+\frac{\partial}{\partial y}\left(K_{y y} \frac{\partial h}{\partial y}\right)+\frac{\partial}{\partial z}\left(K_{z z} \frac{\partial h}{\partial z}\right)-W=S_{s} \frac{\partial h}{\partial t}
$$

where $\mathrm{x}, \mathrm{y}$, and $\mathrm{z}$ are Cartesian coordinates and aligned along the major axes of the hydraulic conductivity tensor

$\mathrm{K}_{\mathrm{xx}}, \mathrm{K}_{\mathrm{yy}}$, and $\mathrm{K}_{\mathrm{zz}}$

$h$ is the head $(L)$;

$\mathrm{W}$ is the volumetric flux per unit volume and represents sources and/or sinks of water $\left(\mathrm{t}^{-1}\right)$;

$S_{\mathrm{s}}$ is the specific storage of the porous medium $\left(\mathrm{L}^{-1}\right)$; and

$\mathrm{t}$ is time ( $\mathrm{t}$ ). 
In general, $S_{\mathrm{s}}, \mathrm{K}_{\mathrm{xx}}, \mathrm{K}_{\mathrm{yy}}$, and $\mathrm{K}_{\mathrm{zz}}$ can be functions of space, and $\mathrm{h}$ and $\mathrm{W}$ can be functions of time and space so that equation 1 describes ground-water flow under nonequilibrium conditions in a heterogeneous and anisotropic medium.

Equation 1, together with specification of flow or head conditions or both at the boundaries of an aquifer and specification of initial head conditions, constitute a mathematical description of ground-water flow. Except for very simple systems, equation 1 has no analytical solutions; therefore, an approximation is used. The McDonaldHarbaugh model uses a cell-centered, finite-difference method to approximate equation 1 . The center of each cell is referred to as a node in the modular model.

This approach leads to a system of simultaneous, linear algebraic equations. The solution of these equations yields values of head at the center of each block at the end of discrete time steps. The size of the cells is selected so that all properties of the aquifer can be considered to be constant over the entire block. The finite-difference equation for the flow through one face of the block is (McDonald and Harbaugh, 1988, p. 13, equation 4):

$$
\mathrm{q}_{\mathrm{i}, \mathrm{j}+1 / 2, \mathrm{k}}=\mathrm{KR}_{\mathrm{i}, \mathrm{j}+1 / 2, \mathrm{k}} \Delta \mathrm{c}_{\mathrm{i}} \Delta \mathrm{v}_{\mathrm{k}} \frac{\left(\mathrm{h}_{\mathrm{i}, \mathrm{j}+1, \mathrm{k}}-\mathrm{h}_{\mathrm{i}, \mathrm{j}, \mathrm{k}}\right)}{\Delta \mathrm{r}_{\mathrm{j}+1 / 2}},
$$

where $q_{i, j+}{ }^{1 / 2}, k$ is the volumetric fluid discharge through the face between nodes $i, j, k$ and $i, j+1, k\left(L^{3} t^{-1}\right)$, for example;

$\mathrm{KR}_{\mathrm{i}, \mathrm{j}+}{ }^{1 / 2, \mathrm{k}}$ is the hydraulic conductivity along the row between nodes and $\mathrm{i}, \mathrm{j}, \mathrm{k}$ and $\mathrm{i}, \mathrm{j}+1, \mathrm{k}\left(\mathrm{Lt}^{-1}\right)$;

$\Delta \mathrm{c}_{\mathrm{i}}$ is the distance between columns $(\mathrm{L})$;

$\Delta \mathrm{v}_{\mathrm{k}}$ is the distance between layers $(\mathrm{L})$;

$h_{i, j+1, k}$ is the head of node $i, j+1, k(L)$;

$h_{i, j, k}$ is the head of node $i, j, k(L)$; and

$\Delta \mathrm{r}_{\mathrm{j}+} 1 / 2$ is the distance between nodes $\mathrm{i}, \mathrm{j}, \mathrm{k}$ and $\mathrm{i}, \mathrm{j}+1, \mathrm{k}(\mathrm{L})$.

The modular model was designed to represent a conceptual hydrogeologic system consisting of aquifers separated by confining layers. The hydraulic connection between aquifer layers is simulated by a vertical conductance factor. Vertical conductance is the vertical hydraulic conductivity of the aquifer multiplied by the horizontal cellface area and divided by the distance between the nodes of the two layers in question. The vertical hydraulic connection between separate aquifer layers was simulated by multiplying the head difference between aquifer layers by the vertical conductance of the confining layer separating the aquifer layers. Boundary conditions were simulated using constant head, specified head, no-flow specified flux, head-dependent flux, and free-surface nodes.

Well withdrawals are a special case of a specified-flux condition. In a three-dimensional model, simulation of well withdrawals from several nodes in a vertical stack adds another level of complexity. In the standard method (defined by McDonald and Harbaugh, 1988) of simulating withdrawals, flow rates are specified for only one layer in a two-dimensional simulation or are distributed among aquifers or layers in a three-dimensional simulation, primarily on the basis of the judgment of the hydrologist. This method does not account for the immediate effect of the withdrawal on the head in the aquifer. In aquifers that are vertically subdivided for simulation without confining layers between screened zones, the only determining factor for the allocation of total well flow among layers is by the vertical distribution of head. Because the detailed measurements of the vertical distribution of head near a producing well are rarely available, the application of the standard method for simulating the change in head caused by well withdrawals in three dimensions would require an arbitrary method for specifying the flow rates from each layer. A number of studies have been published on the calculation of head changes with depth that are caused by well withdrawals--Kuniansky and Hillestad (1980), Chappelear and Williamson (1981), Williamson and Chappelear (1981), and Bennett and others (1982). Most of these studies involve analytical solutions or numerical simulations of analytical solutions of multilayer well-bore flow and are related primarily to petroleum engineering. One of the reasons that field studies of multilayer flow to wells have not been conducted is the difficulty of monitoring pressure and flow rates within or near a pumping well. No well-bore flow or pressure data are available for 
the El Paso wells used in this study; values are only available for total flow rates averaged over finite time spans and relatively "static" water levels in the wells after pumping has ceased.

Wells that are screened in more than one layer in a vertically subdivided-aquifer simulation change the basic finite-difference equation for each node in which a well is located. Instead of the usual six surrounding nodes that directly affect each well node, there can be several more (Bennett and others, 1982). These additional nodes were accounted for in the modular model by the multiaquifer well package (McDonald, 1985). The multiaquifer well package approximates the Thiem equation (Davis and DeWeist, 1966, p. 203) that relates steady-state well withdrawals to the decline in head in the aquifer.

The amount of water that each unit section of well screen yields from the aquifer cannot be measured under normal pumping conditions. The actual flow to the well bore for a given section of well screen is determined by the difference between the potential head within the well bore, the potential head of the aquifer at a distance from the well screen, and the transmissivity of the section of aquifer intersected by the given section of well screen. The pressure in the aquifer at a distance from the well screen is determined by the effective radius of the well. In a finitedifference cell, the effective radius is defined as the distance from a node that has a well to the circular area where the head calculated for that node is assumed to prevail.

The multiaquifer well package requires estimates of the effective radius of a well. The estimate or measurement of the effective radius of the well is important because it is a term in the Thiem equation. Bennett and others (1982) discuss methods of estimating the ratio of the effective well radius to the well radius for a single simulation well. The effective radius of a well is calculated by dividing the square root of the area of the cell containing the well by 4.81. (See Bennett and others, 1982, p. 335 for a discussion of this value.)

\section{Model Design and Parameter Definition}

A number of simplifications and assumptions were necessary to apply the modular model to the Hueco bolson aquifer. Exact boundary conditions rarely are known and must be approximated. Three-dimensional distributions of aquifer properties never are defined completely; accordingly, the distributions must be simplified.

The Hueco bolson aquifer was divided conceptually into four aquifer layers (modular layers 1, 2, 3, and 4) with nodes along the center plane of each layer. The top of the simulated aquifer section was the predevelopment water-table surface. The simulated section included the thickness of aquifer between the predevelopment watertable surface and a surface 1,250 ft below the predevelopment water-table surface. Modular layer 1 was $200 \mathrm{ft}$ thick. Modular layers 2 and 3 were numbered in descending order and were each $350 \mathrm{ft}$ thick. Various cells within layers 1, 2, and 3 represented freshwater and saline water. Modular layer 4 was $350 \mathrm{ft}$ thick and represented saline water. Freshwater and saline water are assumed to have equal density for the modular-model simulations.

Thickness of modular layer 1 was constrained by the thickness of the Rio Grande alluvium. Thickness of the alluvium ranges from 200 to $250 \mathrm{ft}$ (Meyer, 1976) and was assumed to be $200 \mathrm{ft}$ for the modular simulation. A map of the study area with the modular finite-difference grid of the topmost modular layer 1 overlain is shown in figure 11 .

The water table is a free-surface boundary. All nodes, except those along no-flow boundaries and those in the river alluvium, were specified-flux nodes used to simulate diffuse recharge. The nodes in the river alluvium represented head-dependent flux boundaries, used to simulate recharge as a result of leakage from the river and canals and of irrigation return flow. The five nodes at the southeastern comer were constant-head nodes used to simulate underflow out of the region. Little development has taken place in the southeastem comer of the study area, and the water levels have not declined since the beginning of record. These boundary conditions were unique to layer 1 of the simulation.

The boundary conditions that were consistent in all aquifer layers were primarily no-flow conditions, which represented the relatively impermeable bedrock along the Hueco and Franklin Mountains, the Sierra de Juarez, and other mountains to the south of the study area (Meyer, 1976). The bottom of layer 4 was also a no-flow boundary. 


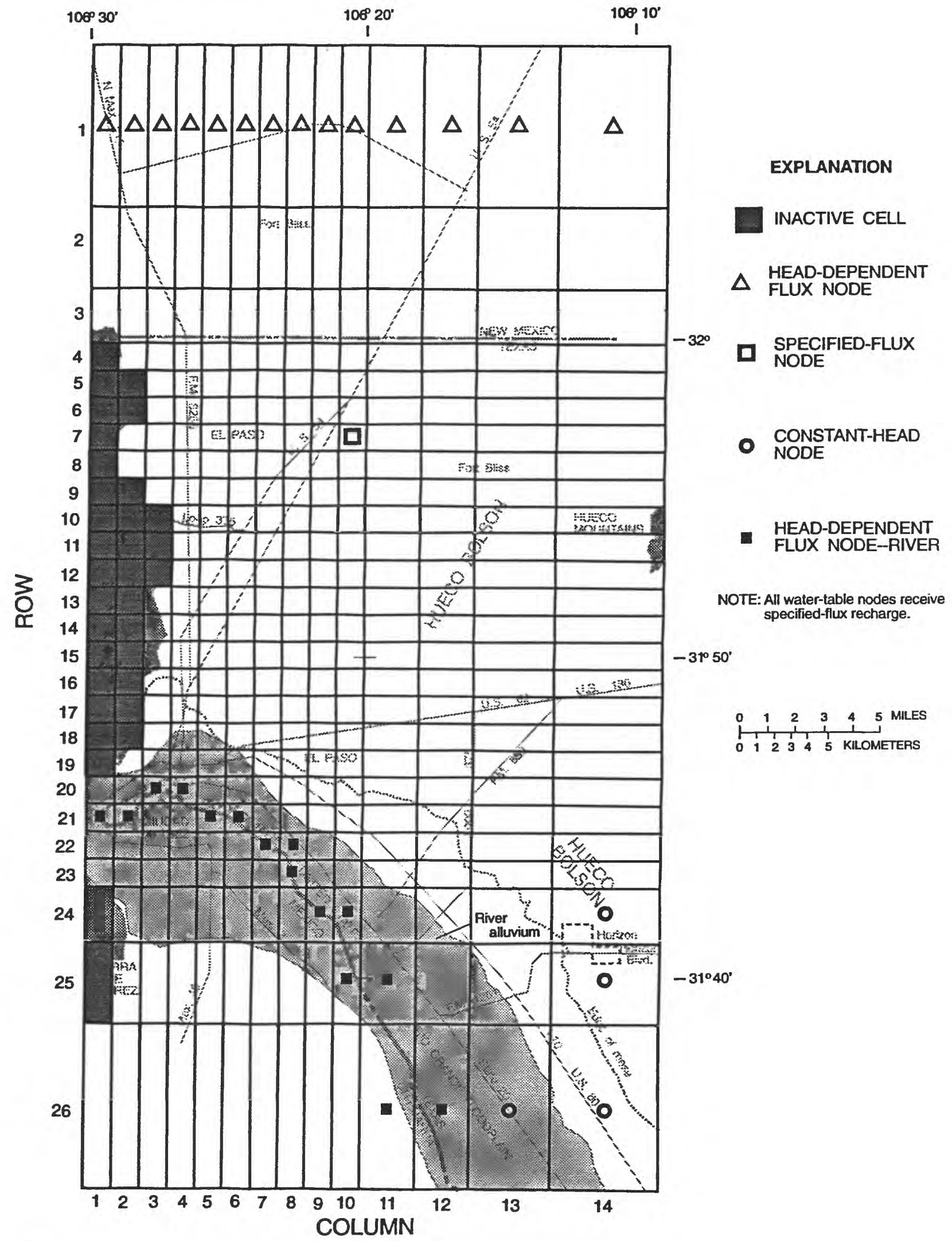

Figure 11. Finite-difference grid for model layer 1 and boundary conditions of the modular model overlain on study area. 
The northern part of the study area has had relatively little development and only slight declines in the water levels. Little change in the water levels is expected in the future; therefore, the northem boundary of the simulation was placed $10 \mathrm{mi}$ into New Mexico to keep the boundary away from the effect of intense pumping in El Paso. A headdependent flux condition imposed in all the layers at the northern edge simulated the flow of water to the south from the northern extension of the bolson in New Mexico. The head-dependent flux condition simulated flows of water at each cell based on the head gradient from a location outside the simulated area to the node just inside the boundary of the area. The head at a point about $6 \mathrm{mi}$ outside the simulated region was considered constant throughout the time period simulated. The north-south length of the northernmost row in the simulation was $6 \mathrm{mi}$. The head-dependent flux condition yielded results similar to a constant-head condition.

Withdrawal rates were taken directly from Meyer (1976) and redistributed by node for the coarser grids used in this study. Four nodes in Meyer's study were equivalent to one node in this study. Therefore, some wells had to be combined into fewer nodes, and some of the withdrawal data had to be distributed approximately. The effect of using a coarser grid changed the actual pattern of ground-water withdrawals, and thus added an amount of uncertainty to the calculated water levels even though the pumping stress was the most accurately known condition in the hydrologic system. The nine pumping periods of various duration used by Meyer (1976) were used for the time from 1903 through 1972. The ground-water withdrawals for 1973-83 were from files of the El Paso Water UtilitiesPublic Service Board, Texas Water Development Board, USGS, and records of the JMAS. The 1973-83 withdrawal data were compiled into eleven 1-year periods.

Horizontal hydraulic conductivity was specified for the water-table layer (layer 1), and transmissivity (the product of hydraulic conductivity and thickness of the layer) was specified for the lower layers. The transmissivity of the lower layers was modified from Meyer (1976) for the four model layers. Initially, the transmissivity from Meyer (1976) was divided by layer according to the thickness of sand layers as interpreted from geophysical well logs. Vertical or areal variations of sand thickness with depth above the underlying saline water were not apparent from the well logs; therefore, an average horizontal hydraulic conductivity of $4 \times 10^{-4} \mathrm{ft} / \mathrm{s}$ (Meyer, 1976) was used to calculate uniform transmissivity for model layers 1,2, and 3. An average horizontal hydraulic conductivity of $3 \times 10^{-6} \mathrm{ft} / \mathrm{s}$ (Meyer,1976) was used to calculate the transmissivity for the underlying saline-water zone (model layer 4).

Although Meyer (1976) gave a range for vertical hydraulic conductivity for the Hueco bolson aquifer of $1.5 \times 10^{-12}$ to $1.5 \times 10^{-5} \mathrm{ft} / \mathrm{s}$, a range of $7.0 \times 10^{-8}$ to $5.0 \times 10^{-6} \mathrm{ft} / \mathrm{s}$ was used in the modular simulation to test the effect of the uncertainty of this aquifer property. The value that provided the best fit $\left(5.0 \times 10^{-7} \mathrm{ft} / \mathrm{s}\right)$ for vertical hydraulic conductivity also determined the ratio of horizontal to vertical hydraulic conductivity. These adjustments in model input value are discussed in detail in a following section.

Treatment of storage properties of the aquifer was simplified from that of Meyer (1976). Data uncertainty and coarse grid size used in the modular simulation did not warrant a variable distribution of the storage properties as used by Meyer (1976). Therefore, a single value of 0.20 was used for specific yield in the water-table layer, and a single value of 0.0005 was used for storage coefficient in layers 2-4.

Simulation of withdrawals from wells was approximate partly because the flow rate was given as the total for all wells within a well field in many cases. Approximations also resulted from estimating withdrawals as step functions in time and from the coarse spatial grid. For a number of nodes, several wells were included as a single well. Combining wells tended to focus drawdown toward the center of the cell unlike the more distributed drawdown that actually occurs in the aquifer. This effect is counteracted, to some extent, by the averaging of the simulated withdrawal over the entire cell. The combining of flow from several actual wells into one simulated well was done primarily for the area representing the aquifer south of the river in the Ciudad Juarez area where wells are closely spaced. Calculated water levels in the Ciudad Juarez area were less representative than those for the rest of the bolson where wells are more sparsely distributed. Calculated water levels in the Ciudad Juarez area were higher than measured water levels, and the area of simulated water-level decline was larger than water-level measurements indicated. 


\section{Model Adjustments}

Initial estimates of aquifer properties and conditions were adjusted to yield simulated head values that more closely approximated those observed in the field. In the process of adjusting aquifer properties and conditions, some changes to the model of the aquifer were necessary.

Aquifer properties and conditions were adjusted on the basis of the match between simulated and observed heads and the match between simulated and estimated components of the water budget. Unfortunately, although there are many water-level measurements, most measurements were made in municipal-supply wells. Because the water levels in many of these wells are vertical composites of heads throughout the length of the screen or screened sections and are not representative of the head at any point in the aquifer, few reliable data exist on the actual head in the aquifer. Furthermore, the estimates for each water-budget component (table 1) were based on uncertain or sparse data.

First, a steady-state simulation was made to represent conditions prior to ground-water development. After adjustments to the model parameters were made so that the simulated water levels and water budget components were in agreement with estimates of predevelopment conditions, the period of historical ground-water development (1903-83) was simulated. A match of predevelopment simulated head with observed or estimated head was achieved by adjusting those aquifer properties or conditions that were least well known. The aspects of the flow system that were the least understood or measured were the boundary conditions (other than the no-flow conditions), the vertical hydraulic conductivity, and (indirectly because of the uncertainty in vertical hydraulic conductivity) the recharge rate to the river alluvium. No adjustments to the horizontal hydraulic conductivity were made because this is the best known aquifer property.

Adjustments to the vertical hydraulic conductivity were the most effective in matching observed and simulated water levels for the historical period. Adjustments to other aquifer properties were not needed. The best-fit value for the vertical hydraulic conductivity was determined using the predevelopment steady-state simulation and the historical period transient simulation. The constraint under the predevelopment conditions was the assumption of an upward vertical gradient of 1:1,250 to 10:1,250 ft/ft for the deep bolson deposits undemeath the Rio Grande. This is in accordance with the assumption that ground water from the Hueco bolson aquifer discharges to the river area. For the historical pumping conditions, the constraint was to approximate the net river leakage to the bolson deposits as estimated by Meyer and Gordon (1972) and Meyer (1976).

The ratio of horizontal to vertical hydraulic conductivity was determined by the best-fit value of $5 \times 10^{-7} \mathrm{ft} / \mathrm{s}$ for the vertical hydraulic conductivity because changes to the horizontal hydraulic conductivity were avoided. The ratio in the modular simulation was a maximum of about 960:1 in the zone of greatest horizontal hydraulic conductivity. The ratio within the freshwater part of the aquifer ranged from 180:1 to 960:1. This range resulted, not from an effort to adjust the value of the ratio, but from the fact that one vertical hydraulic-conductivity value and a variable value of horizontal hydraulic conductivity were used for all layers.

\section{General Description of Solute-Transport Model}

For the final phase of the study, a three-dimensional, finite-difference simulator of ground-water flow and transport of solute and thermal energy was used to simulate the movement of saline water caused by withdrawals. The HST3D model (Kipp, 1987) was based on a computer program originally developed for the USGS by INTERCOMP Resource Development and Engineering, Inc. (1976) and INTERA Environmental Consultants, Inc. (1979). The program solved for three independent variables--pressure, temperature, and solute fraction in one-, two-, or three-dimensional Cartesian coordinates. 
The nonlinear partial differential equation that solved for the pressure field in three dimensions is (Kipp, 1987 , p. 29, equation 2.3.1a):

$$
\varepsilon \rho_{\mathrm{o}} \beta_{\mathrm{p}} \frac{\partial \mathrm{p}}{\partial \mathrm{t}}+\varepsilon \rho_{\mathrm{o}} \beta_{\mathrm{T}} \frac{\partial \mathrm{T}}{\partial \mathrm{t}}+\varepsilon \rho_{\mathrm{o}} \beta_{\mathrm{w}} \frac{\partial \mathrm{w}}{\partial \mathrm{t}}+\rho \alpha_{\mathrm{b}} \frac{\partial \mathrm{p}}{\partial \mathrm{t}}=\nabla \bullet \rho \frac{\mathrm{k}}{\mu}(\nabla \mathrm{p}+\rho \mathrm{g})+\mathrm{q} \rho^{*},
$$

where $\varepsilon$ is effective porosity (dimensionless);

$\rho$ is the fluid density (pounds-mass per cubic foot);

$\rho_{o}$ is the fluid density at a reference pressure, $p_{0}$, temperature, $T_{0}$, and mass fraction, $w_{0}$, (pounds-mass per cubic foot);

$\beta_{p}$ is the fluid compressibility (pounds per square inch $^{-1}$ );

$\mathrm{p}$ is the fluid pressure, (pounds per square inch relative to atmospheric);

$t$ is time (seconds);

$\beta_{\mathrm{T}}$ is the fluid coefficient of thermal expansion (degrees Fahrenheit ${ }^{-1}$ );

$T$ is the temperature (degrees Fahrenheit);

$\beta_{\mathrm{w}}$ is the slope of the fluid density as a function of mass fraction divided by the reference fluid density (dimensionless);

$\mathrm{w}$ is the mass fraction of solute in the fluid phase (dimensionless);

$\alpha_{b}$ is the bulk compressibility of the porous medium (pounds per square inch ${ }^{-1}$ );

$\nabla$ is gradient;

$\underline{\underline{\mathrm{k}}}$ is the porous-medium intrinsic permeability tensor (square feet);

$\mu$ is the fluid viscosity (centipoise);

$\mathrm{g}$ is the gravitational constant (feet squared per second);

$q$ is the fluid-source flow-rate intensity (cubic feet per square foot per second), (positive is into the region); and

$\rho^{*}$ is the density of a fluid source (pounds-mass per cubic foot).

Constant pressure, specified pressure, no flow, specified flux, pressure-dependent flux, and free surface are boundary conditions simulated using the HST3D model.

The equation for the transport of solute in the HST3D model is (Kipp, 1987, p. 30, equation 2.3.1c):

$$
\begin{array}{r}
\rho_{\mathrm{o}} \beta_{\mathrm{p}}\left(\varepsilon+\rho_{\mathrm{b}} \mathrm{K}_{\mathrm{d}}\right) \mathrm{w} \frac{\partial \mathrm{p}}{\partial \mathrm{t}}+\rho_{\mathrm{o}} \beta_{\mathrm{T}}\left(\varepsilon+\rho_{\mathrm{b}} \mathrm{K}_{\mathrm{d}}\right) \mathrm{w} \frac{\partial \mathrm{T}}{\partial \mathrm{t}}+\rho_{\mathrm{o}} \beta_{\mathrm{w}}\left(\varepsilon+\rho_{\mathrm{b}} \mathrm{K}_{\mathrm{d}}\right) \mathrm{w} \frac{\partial \mathrm{w}}{\partial \mathrm{t}}+\rho \alpha_{\mathrm{b}} \mathrm{w} \frac{\partial \mathrm{p}}{\partial \mathrm{t}} \\
+\rho\left(\varepsilon+\rho_{\mathrm{b}} \mathrm{K}_{\mathrm{d}}\right) \frac{\partial \mathrm{w}}{\partial \mathrm{t}}=\nabla \bullet \varepsilon \rho\left[\underline{\underline{D}}_{\mathrm{S}}+\mathrm{D}_{\mathrm{m}} \underline{\underline{I}}\right] \nabla_{\mathrm{w}}-\nabla \bullet \varepsilon \rho \underline{\mathrm{v} w}-\lambda\left(\varepsilon+\rho_{\mathrm{b}} \mathrm{K}_{\mathrm{d}}\right) \rho_{\mathrm{w}}+q \rho^{*} \mathrm{w}^{*},
\end{array}
$$

where $\rho_{b}$ is the bulk density of the porous medium (pounds-mass per cubic foot);

$\mathrm{K}_{\mathrm{d}}$ is the equilibrium-distribution coefficient for the ratio of solute in the solid phase to that in the fluid phase

(cubic feet per pound-mass);

$\underline{\underline{D}}_{s}$ is the mechanical-dispersion-coefficient tensor (feet squared per second);

$\mathrm{D}_{\mathrm{m}}$ is the effective-molecular diffusivity of the solute (square feet);

$\underline{\underline{I}}$ is the identity matrix of rank 3 (dimensionless);

$\underline{\underline{v}}$ is the interstitial velocity from the equation:

$$
\underline{\mathrm{v}}=\frac{\underline{\underline{\mathrm{k}}}}{\varepsilon \mu}(\nabla \mathrm{p}+\rho \mathrm{g})
$$

$\lambda$ is the linear-decay constant ( seconds $^{-1}$ ); and

$\mathrm{w}^{*}$ is the mass fraction of solute in the fluid source (dimensionless).

For all the simulations discussed in this report, the dissolved-solids concentrations were assumed conservative; that is, unaffected by chemical reactions or radioactive decay. Accordingly, $\mathrm{K}_{\mathrm{d}}$ is unity, and $\lambda$ is 0 . 
The mass-fraction concentration can be entered as absolute mass fractions (mass solute $_{\text {mass }} /$ fluid $_{\text {) or as relative }}$ fractions scaled by the equation:

$$
w^{\prime}=\frac{w-w_{\text {min }}}{w_{\text {max }}-w_{\text {min }}},
$$

where $\mathrm{w}^{\prime}$ is the scaled solute-mass fraction (dimensionless);

$\mathrm{w}_{\min }$ is the minimum solute-mass fraction (dimensionless); and

$\mathrm{w}_{\max }$ is the maximum solute-mass fraction (dimensionless).

Heat-related water movement was considered negligible, and therefore, the heat-transport equation of the HST3D computer code was not solved. Viscosity was assumed constant at 1.00 centipoise.

A major difference between the solution of the flow equation in the HST3D simulation and in the modular simulation is that the HST3D solution was fully three-dimensional. The finite-difference equations in the HST3D model were solved similarly for all three directions. Furthermore, the finite-difference equations of the HST3D model were developed for a mesh-centered (point-centered) grid rather than a cell-centered grid (Kipp, 1987). The simulated heads and concentrations of solute, therefore, are not at the center of the simulated layer, as they would be in a cell-centered simulation, because, unlike the modular simulation, the planes of nodes lie at the tops and bottoms of the simulated aquifer layers.

Other coefficients used in the HST3D model described the thermal characteristics of the fluid and the aquifer. Various constant-condition or dynamic-boundary specifications described fluxes of water, solute, and heat at the boundaries of the model grid. The boundary conditions for the solute equation were constant concentration, specified concentration, and specified mass-flux.

Boundary conditions for wells completed in more than one layer were accounted for in the well-bore part of the HST3D simulations (Kipp, 1987). This method is based on a modification of the Thiem equation. The HST3D model calculated the effective radius of a well using the method developed by Thomas (1982) and on the basis of cell size of the well node. The model calculated flow rate per layer either explicitly, using the pressures and concentrations of the present time step, or implicitly, using the calculated pressures and concentrations of the previous iteration. The implicit method required repeated iterations to adjust the total well flow to less than 5-percent error but added stability to the overall pressure solution. The explicit method was too unstable for the Hueco bolson aquifer simulation, so the implicit method was used in all the simulations.

\section{Model Design and Parameter Definition}

Results of modular simulation of the Hueco bolson aquifer were used to develop a flow simulation using the HST3D model. The point-centered grid for the HST3D model (fig. 12) overlies the cell-centered grid of the modular model (fig. 11) such that node points of the HST3D grid fall in the centers of modular-model grid cells, with three exceptions--node points that fall in modular rows 3 and 24 and modular column 11 are offset from the centers 2,640 ft south, north, and west, respectively. The HST3D simulation used four aquifer layers but included the complexity of salinity and density variations. Although the HST3D simulation had four layers like the modular simulation, the nodes were in planes between the layers, so there were actually five nodal planes. The vertical grid used in the HST3D simulation is shown for sections $A-A^{\prime}$ (fig. 13) and $B-B^{\prime}$ (fig. 14). The vertical grid used in the modular simulation also is shown in figure 13.

The top node plane in the HST3D simulation, node-layer A, was at an altitude of $3,600 \mathrm{ft}$ above sea level. The altitude of node-layer B, between aquifer layer 1 and aquifer layer 2, was $3,300 \mathrm{ft}$ above sea level. The altitude of node-layer $\mathrm{C}$, between aquifer layers 2 and 3 numbered in descending order, was 3,000 ft above sea level. The altitude of node-layer $\mathrm{D}$, between aquifer layers 3 and 4, was $2,700 \mathrm{ft}$ above sea level. The altitude of node-layer $\mathrm{E}$, located at the bottom of aquifer layer 4 , was $2,400 \mathrm{ft}$ above sea level. 


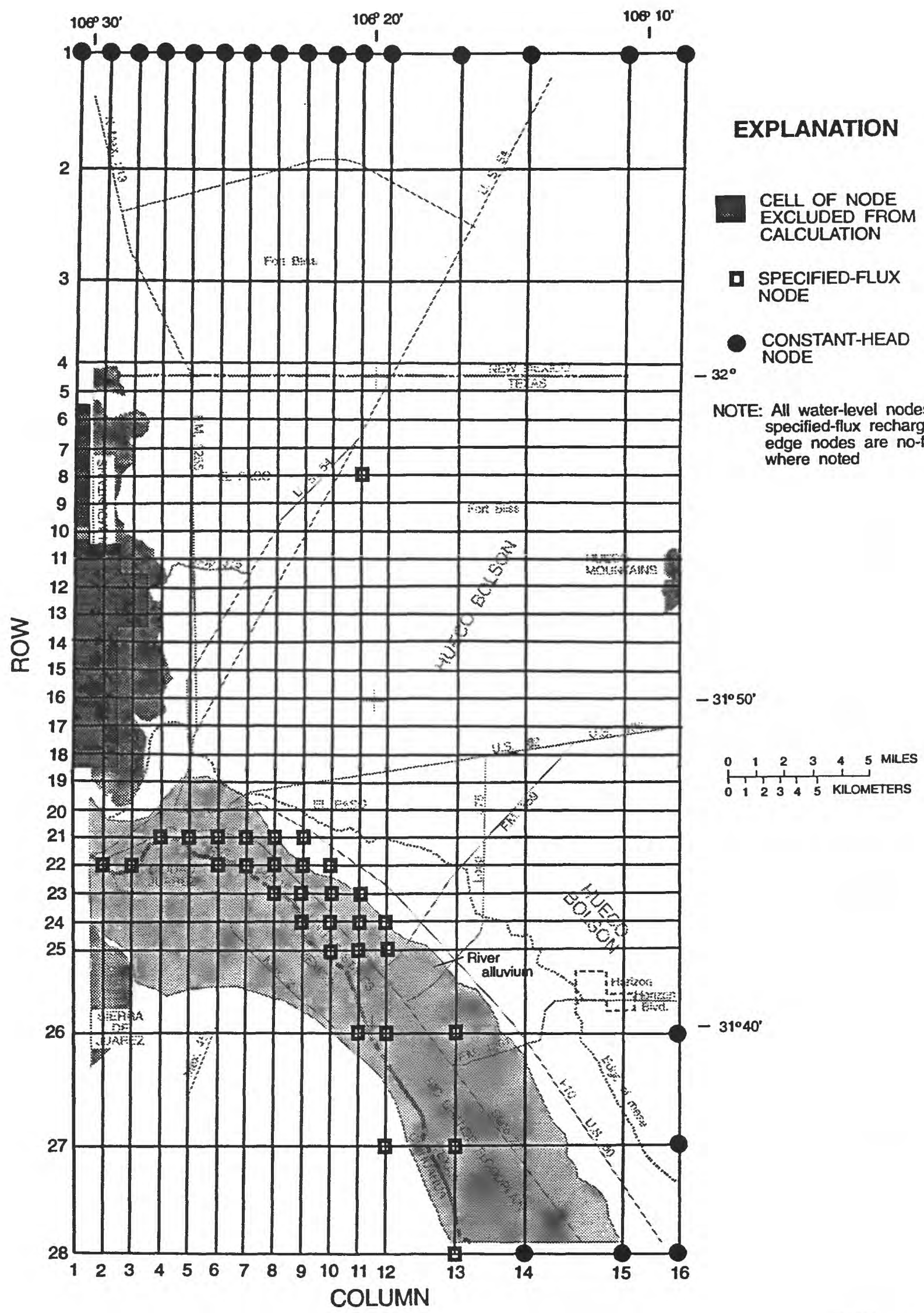

Figure 12. Finite-difference grid for node-layer $A$ and boundary conditions of the heat- and solute-transport threedimensional model overlain on study area. 


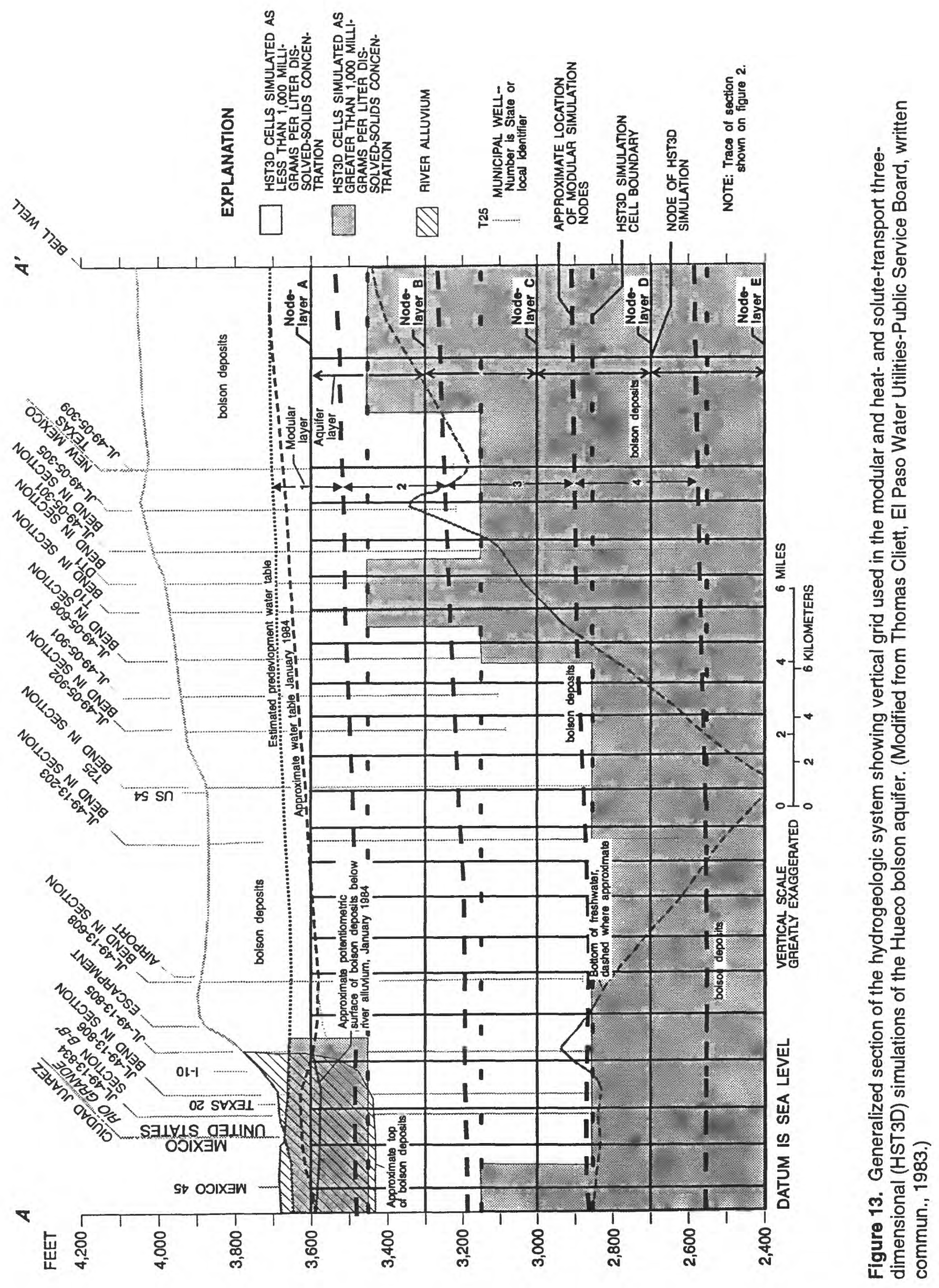




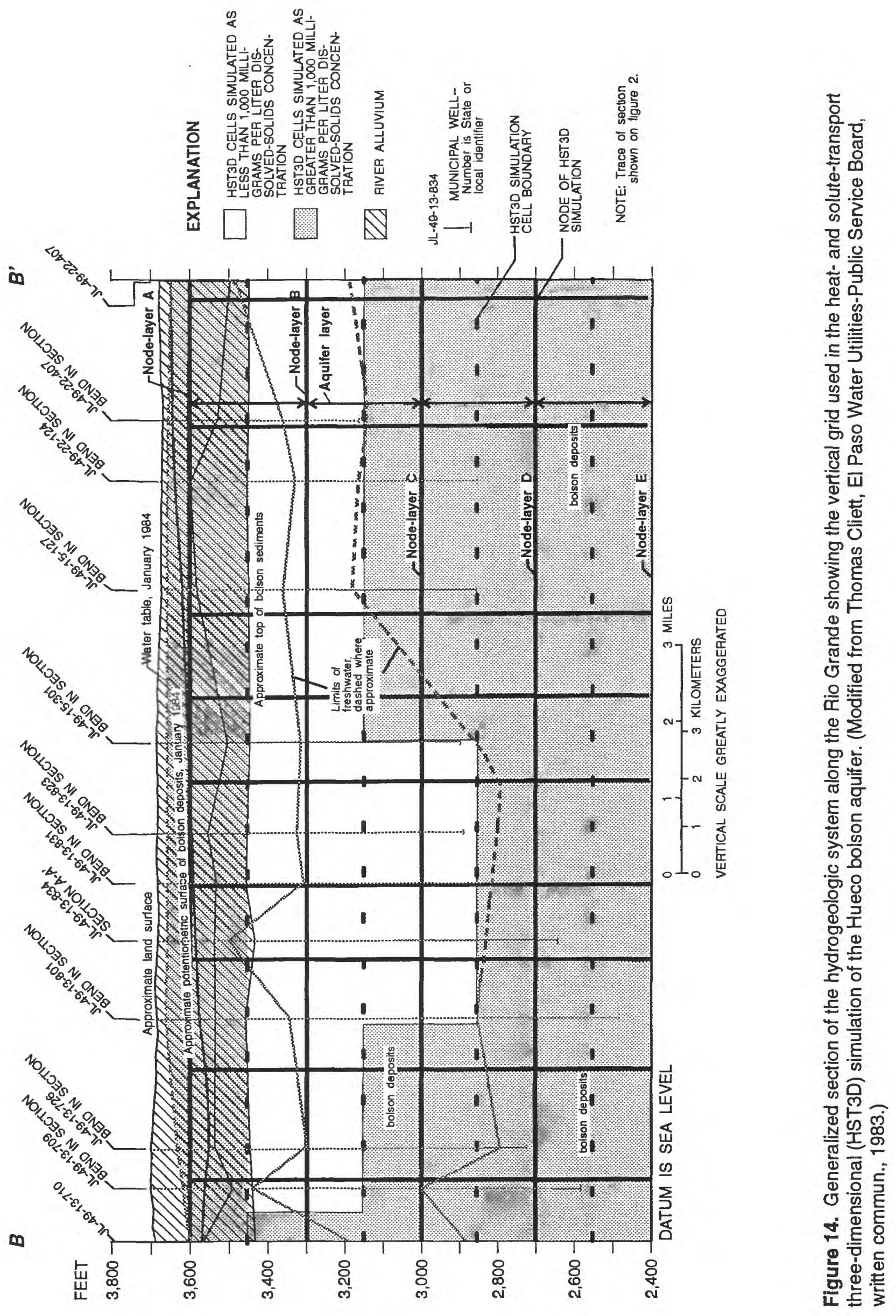


The thickness of the top cell was the vertical distance between the predevelopment water-table surface and an altitude of $3,450 \mathrm{ft}$ above sea level. The thickness ranged from about 200 to $300 \mathrm{ft}$. The HST3D model was not capable of simulating the dewatering of the top layer of cells (blocks of aquifer material) and transferring the free-surface boundary to the underlying layer. The heat-and-solute mass balances that were required to account for the movement of the free surface boundary were too complex to have been included. At the beginning of the transport simulation, the water table was above node-layer A in the top cell. As the simulation proceeded, the water table declined to the bottom of the top cell. The bottom of the top cell was located at the center plane of the top layer of the simulated aquifer (aquifer layer 1). This limited the amount of drawdown that the HST3D could simulate. Aquifer layer 1 could have been made thicker to allow for greater drawdown, but this would have destroyed the vertical spacing needed to accurately represent the Rio Grande alluvium and the slightly saline water that it contains. The specifications for aquifer layer 1 allowed for $200 \mathrm{ft}$ of water-table decline in the thinnest cells.

The flow rates for the nodes in the river alluvium that were calculated by the modular simulation were used to estimate the node-by-node recharge and discharge during the historical and projected pumping periods for the specified-flux nodes in the HST3D simulation. This method of estimating fluxes was done, in part, because the HST3D simulation data specifications did not allow for transient changes in the riverbed permeability--such as would be required for the permeability change caused by lining of the river channel in 1968 . The nodes in the river alluvium that were head-dependent flux boundaries in the modular simulations were specified-flux nodes in the HST3D simulation.

A constant-pressure boundary was used and adjusted to simulate the flow of water southward from the area north of the study area. This boundary condition generally yielded flow rates similar to those calculated by the modular simulation using the head-dependent boundary. Except for the northern boundary and river nodes, all other boundary conditions were identical to those used in the modular simulation. Where influx of water was expected from constant-pressure nodes, the influx of water was assigned a specified concentration of dissolved solids. In the river-alluvium recharge nodes, the concentration was held constant. This was necessary because the simulation had specified wells in some of these recharge nodes, and many nodes directly underneath the recharge nodes were also well nodes. The added complexity caused by the proximity of well nodes created instability in the solution of the solute-transport equation. The approximation of a constant dissolved-solids concentration did not affect the accuracy of the calculated concentrations, but it did complicate the solute mass balance. Nevertheless, all calculated mass balances were correct to within 1 percent.

Hydraulic conductivity is a property of both porous medium and fluid. The HST3D simulation used intrinsic permeability, which is a property only of porous medium. In discussion of the various simulations, hydraulic conductivity was used to refer to the property specified in the modular simulation, and permeability was used for the aquifer property specified in the HST3D simulation. Permeability was specified for all three directions in the HST3D simulation. The horizontal intrinsic permeability used for the four aquifer layers is shown in figure 15 . A single value of $1.85 \times 10^{-13} \mathrm{ft}^{2}$ was used for vertical permeability. Aquifer storage was defined by specifying the effective porosity, layer thickness, density, and compressibility of water and porous medium.

The distribution of hydraulic conductivity and the equivalent intrinsic permeability (assuming viscosity is 1.00 centipoise) yielded a transmissivity that was similar to the range of transmissivity values used by Meyer (1976) with minor adjustments. Meyer's (1976) transmissivity distribution had several small areas of substantially greater transmissivity surrounded by areas of lesser transmissivity. The adjusted distribution of hydraulic conductivity used in the modular simulation discussed in this report did not have any such small areas, but the overall transmissivity was increased over a large area of the freshwater zone to create a smoother distribution. This was necessary because the data requirements of the HST3D simulation were extensive and complex, and many steps were necessary for conversion of the modular-simulation data to the HST3D simulation. Furthermore, the complex (and estimated) distribution of transmissivity of Meyer (1976) was not warranted by the amount and quality of the available data.

Estimated dissolved-solids concentrations for node-layers A, B, C, and D under predevelopment (1903) conditions are shown in figure 16 . Because few water-quality data were available prior to 1958 , the simulated predevelopment concentrations cannot be compared to actual values. 
Layer 1

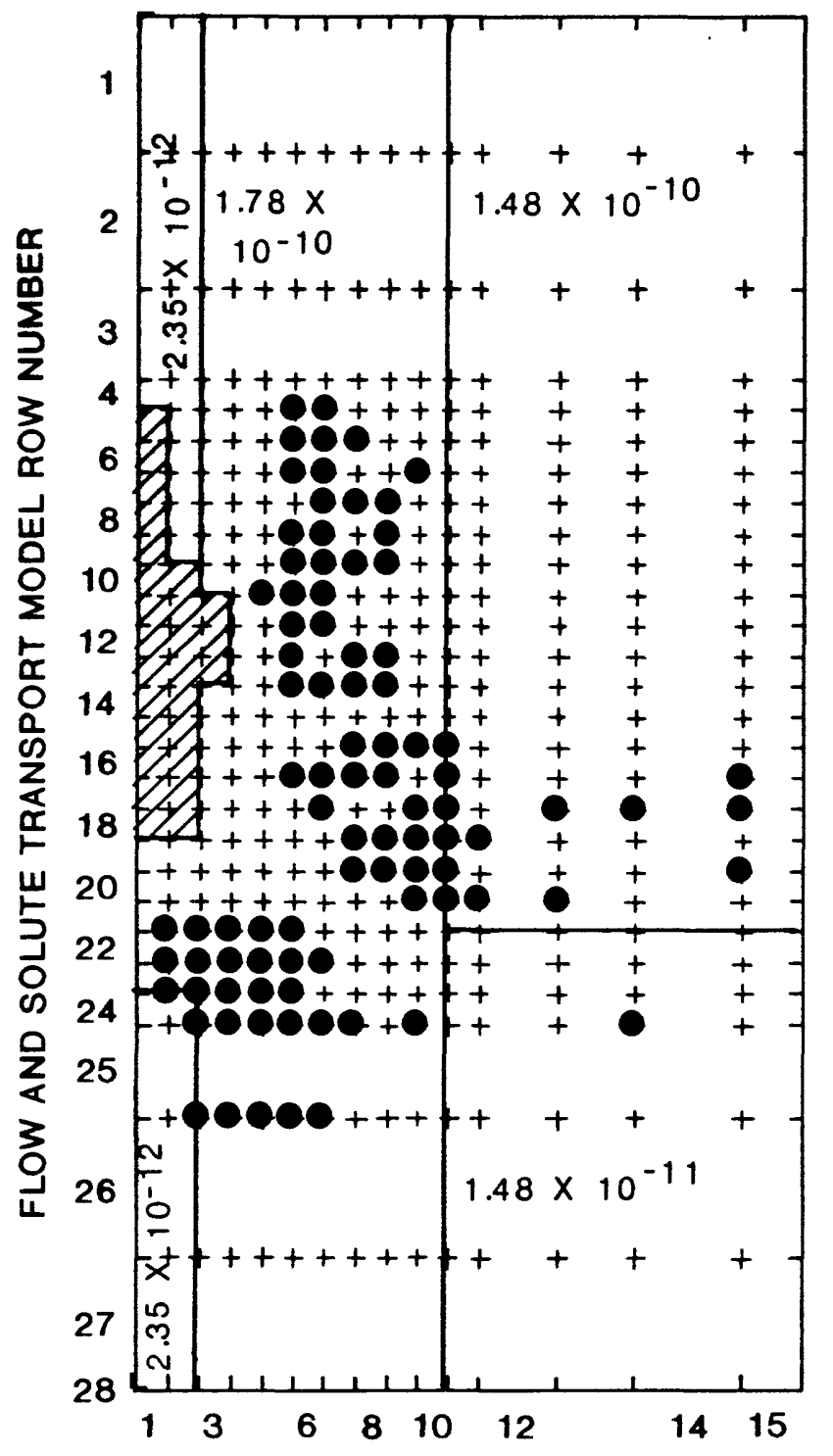

Layer 2

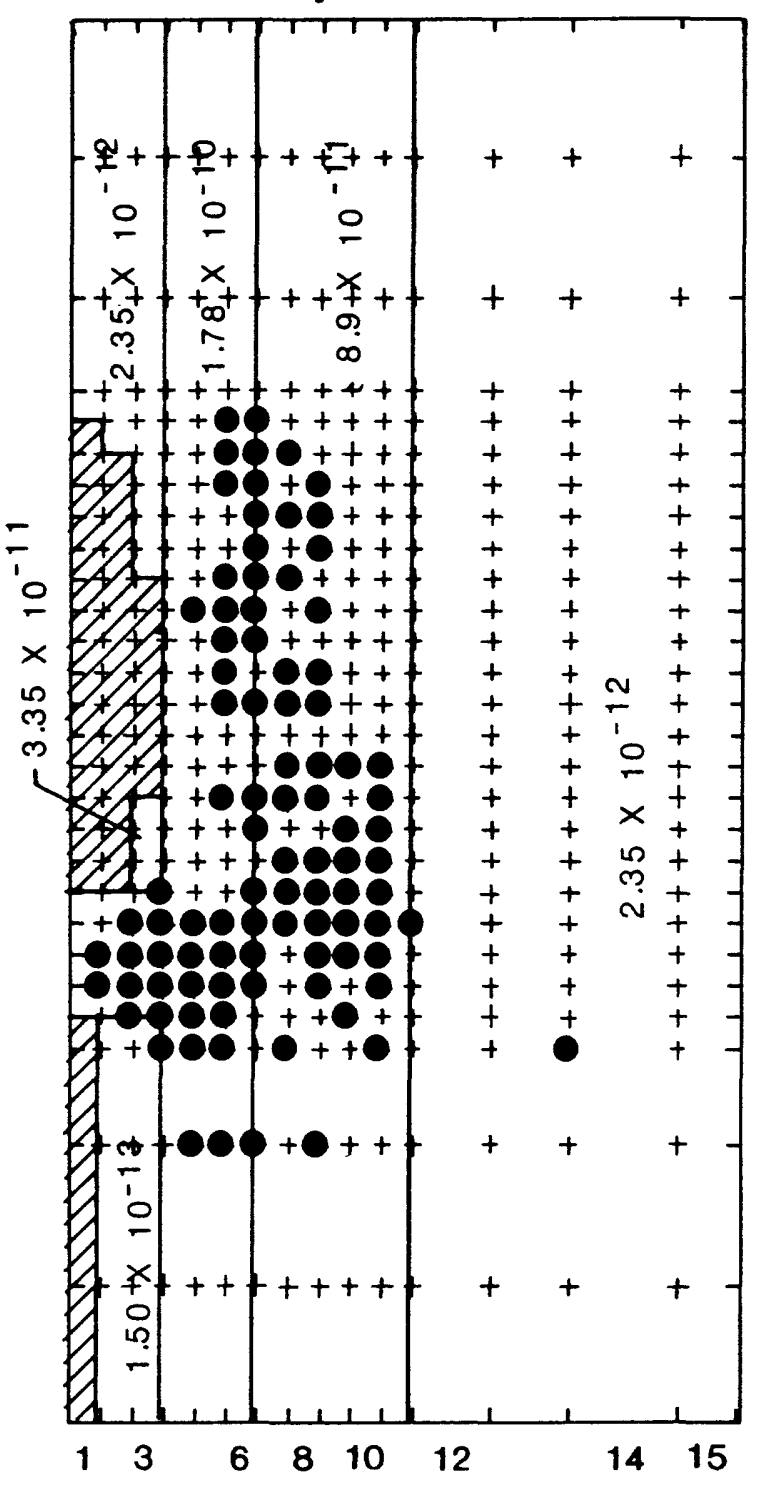

FLOW AND SOLUTE TRANSPORT MODEL COLUMN NUMBER

\section{EXPLANATION}

INACTIVE CELLS

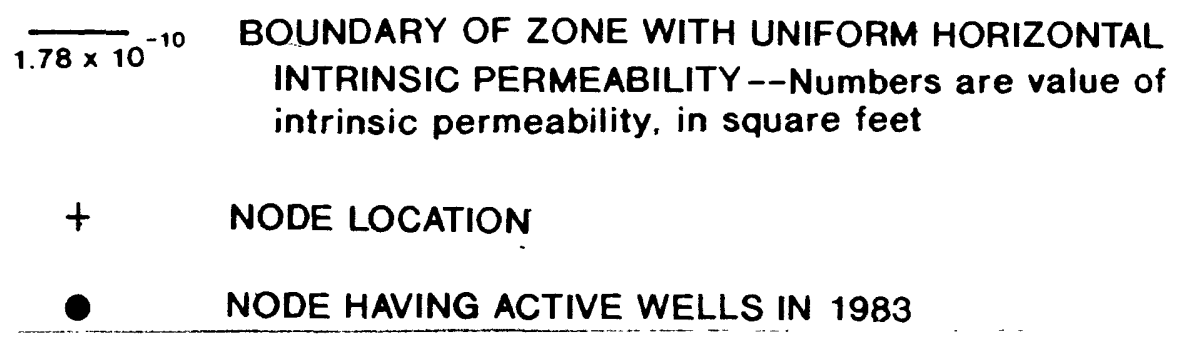

Figure 15. Schematic maps showing distribution of horizontal intrinsic permeability in aquifer layers. 
Layer 3

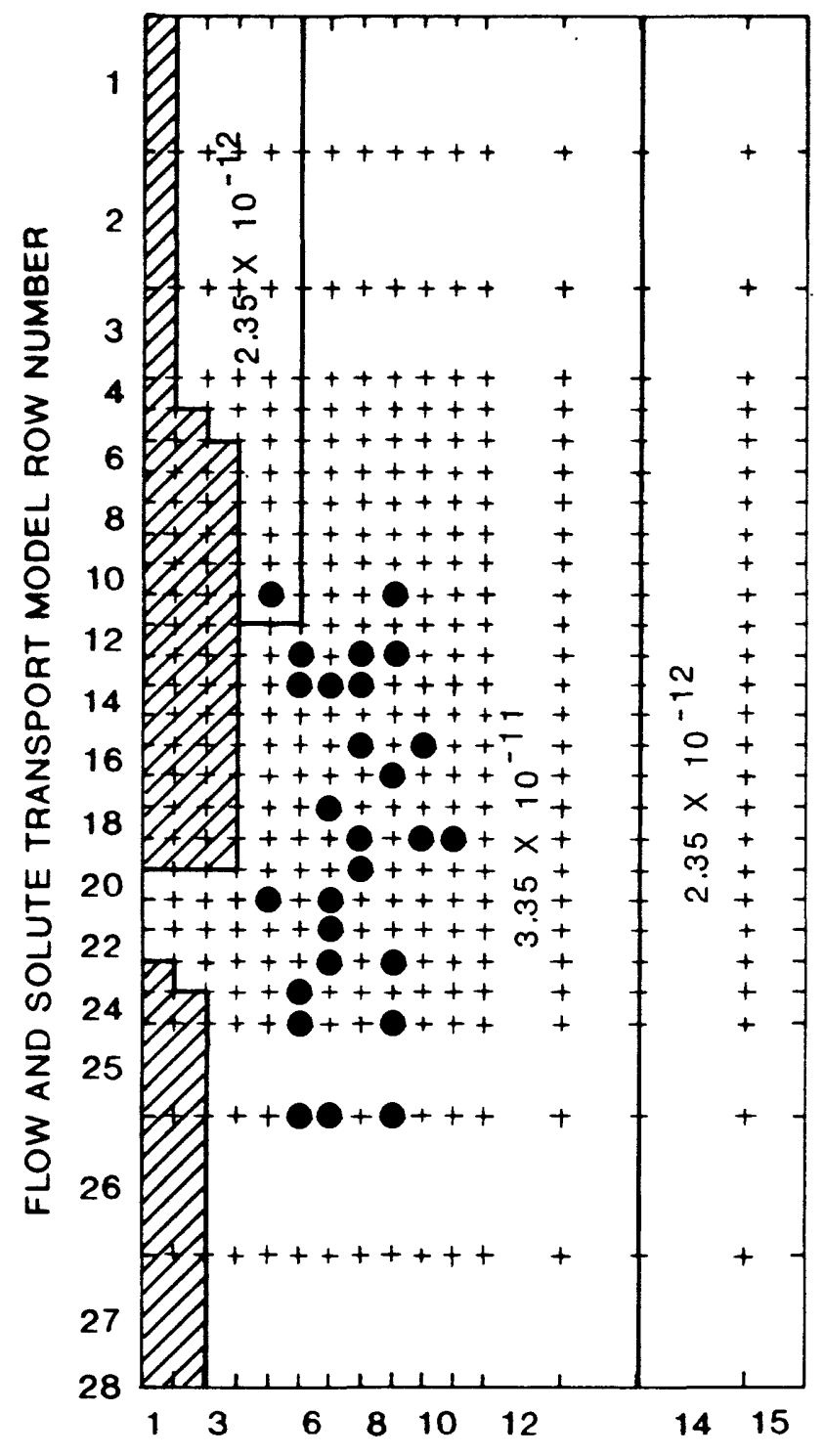

Layer 4

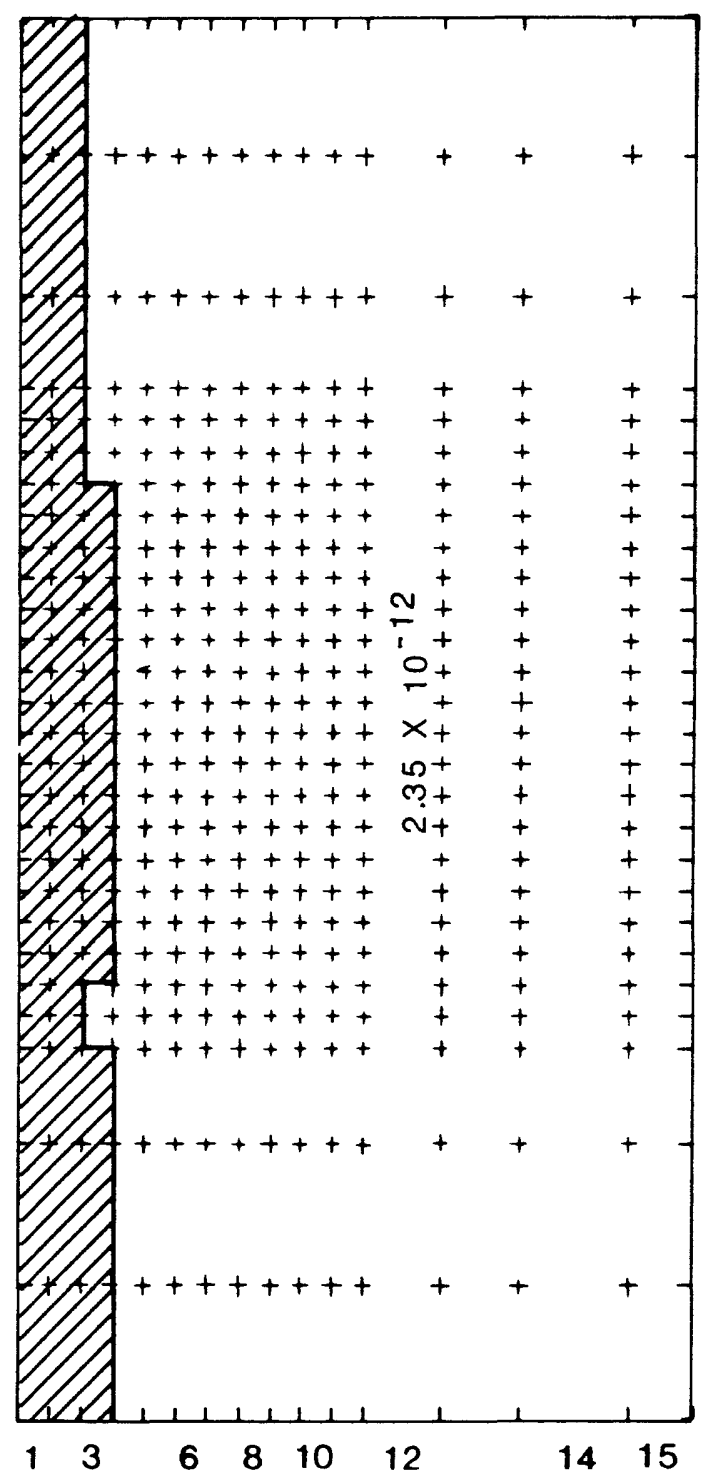

FLOW AND SOLUTE TRANSPORT MODEL COLUMN NUMBER 

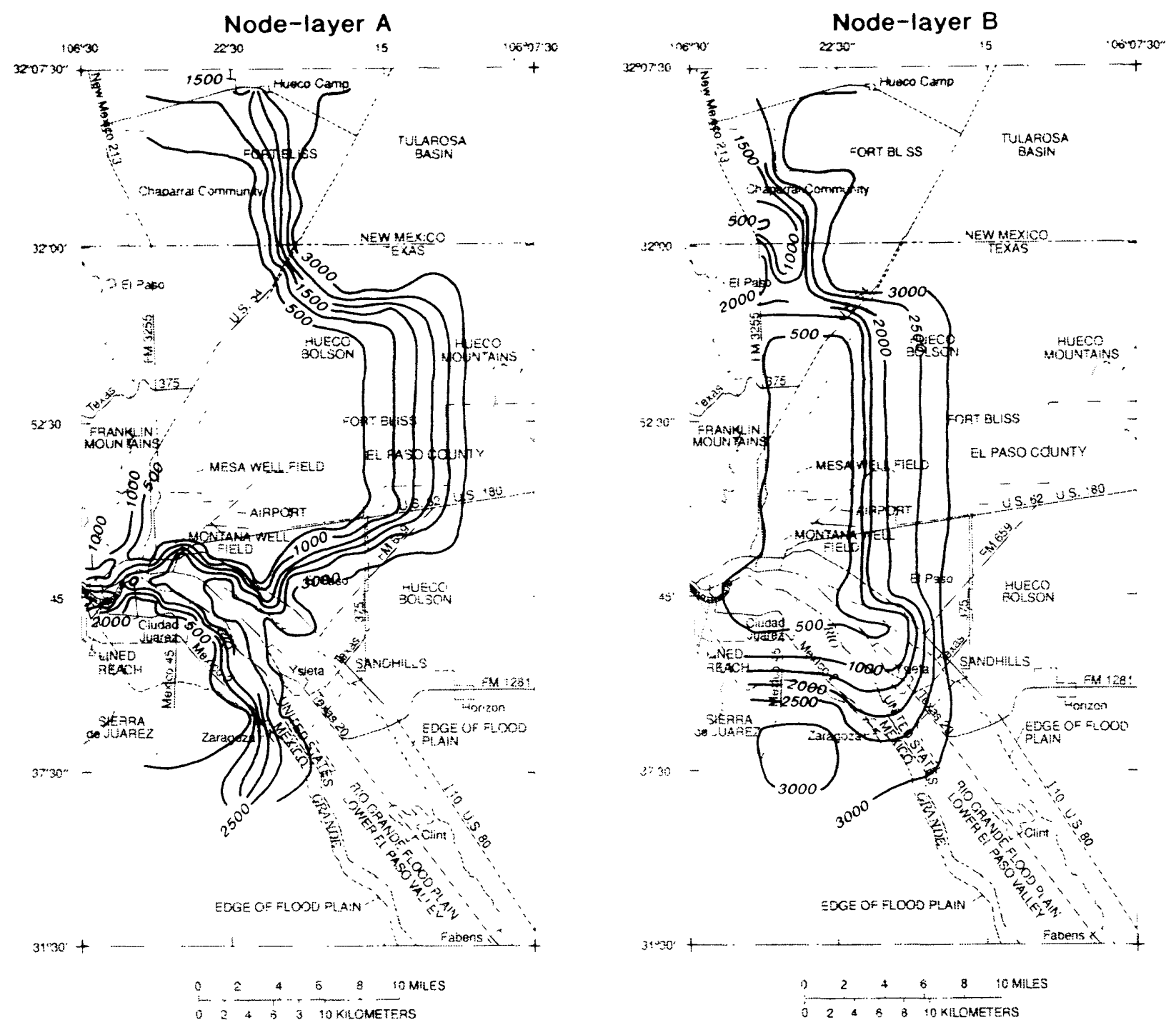

EXPLAMATION

- 1000 - LINE OF EOUAL ESTMMATED DISSOLVED-
SOLIDS CONCENTRATION---Interval 500 milligrams per liter

Figure 16. Estimated predevelopment dissolved-solids concentrations in node-layers A, B, C, and D of the Hueco bolson aquifer. (Modified from Knowles and Kennedy, 1958; White, 1983; and Thomas Cliett, El Paso Water Utilities-Public Service Board, written commun., 1983.) 

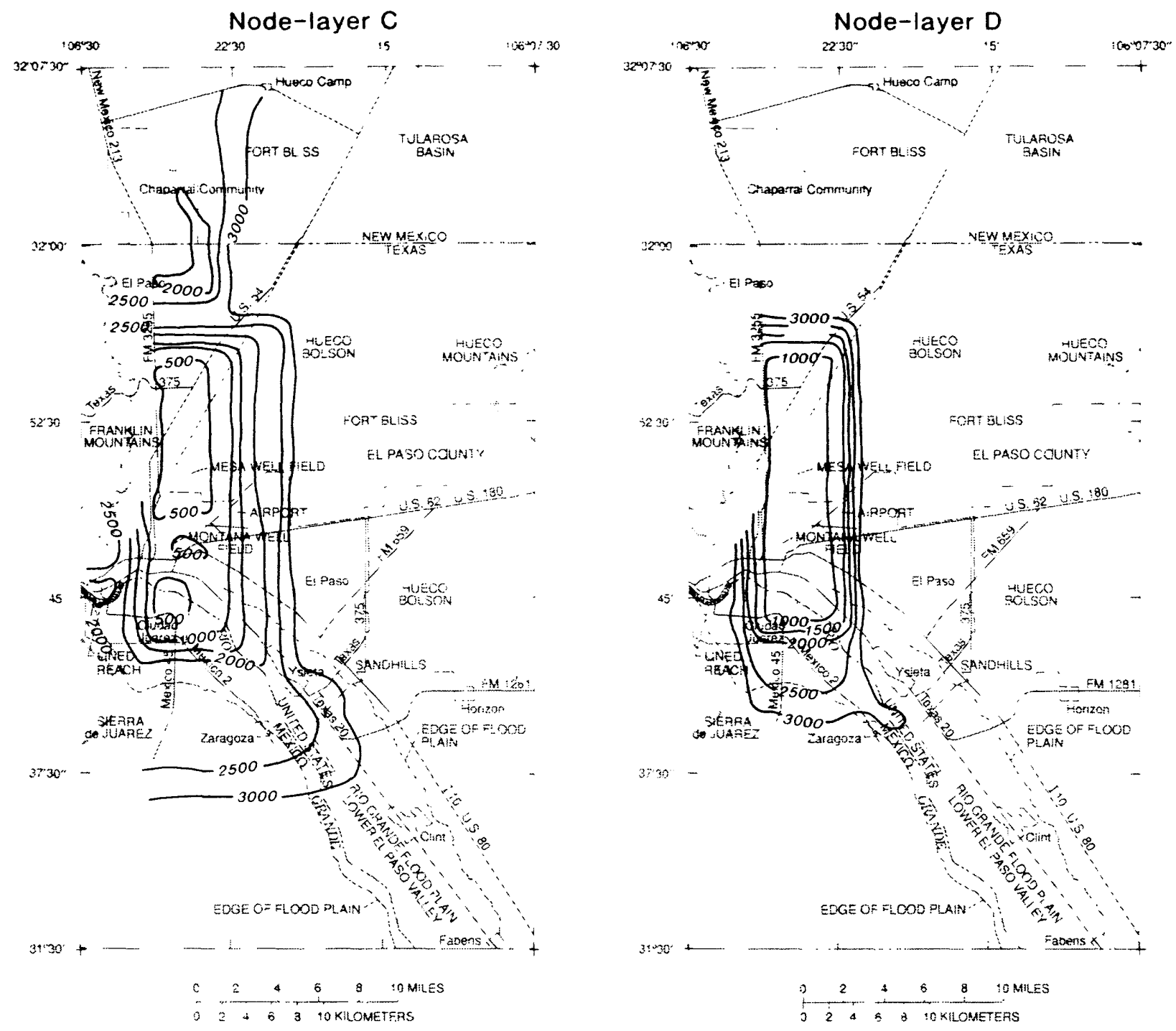


\section{Model Adjustments}

The HST3D simulation incorporated all the conceptual changes resulting from the modular simulation. Unequivocal data on historical changes in regional water quality were not available for a time period corresponding to that of the solute-transport part of the HST3D simulation. The HST3D model satisfactorily simulated the near steady-state salinity conditions assumed to prevail for most of the historical period after adapting the aquifer properties and conditions estimated and adjusted in the modular simulation.

The two criteria for assessing the goodness-of-fit of the HST3D simulation were: (1) no significant movement of saline water (resulting in increases in concentration of 10 percent or greater) in areas where only freshwater is known to exist; and (2) no saline-water flow at simulation boundaries such as the river nodes, the southeastem comer of the study area, or in wells during the predevelopment simulation and during the historical simulation from 1903-58. Neither of the two conditions was observed in the field. The distribution of dissolved-solids concentrations in the top four node layers (A, B, C, and D) at the beginning of 1958 , was assumed to be similar to the estimated predevelopment conditions. The simulated changes in dissolved-solids concentrations for nodes that were initially freshwater (less than or equal to $1,000 \mathrm{mg} / \mathrm{L}$ dissolved solids) during the simulation for 1903-58 in nodelayers A, B, and C are shown in figure 17 . Only changes in dissolved-solids concentrations greater than $100 \mathrm{mg} / \mathrm{L}$ were considered significant and only increases in salinity are shown, although some decreases in salinity did occur in the saline-water zone.

The changes shown in figure 17 reflect errors resulting from uncertainties in model input values and errors inherent in the simulation. The possible sources of these errors are: (1) inaccurate estimates of predevelopment salinity distribution; (2) poorly defined or inaccurately positioned steep concentration gradients; (3) inaccurate estimate of hydraulic conductivity distribution; and (4) numerical dispersion. The significance of the first three of the above listed errors cannot be determined because of insufficient data. The fourth possible error, numerical dispersion, is discussed in a section of this report entitled "Dispersion."

Some areas, especially in the slightly saline water near the eastern boundary between freshwater and saline water, showed decreases in salinity, whereas the freshwater cells adjacent to them showed increases. Most increases occurred within freshwater cells near steep concentration gradients. The probable cause of these changes is numerical dispersion. Because numerical dispersion is unavoidable for the finite-difference technique used, these errors of simulated concentration were considered acceptable and no changes to the estimated aquifer properties or conditions were made.

\section{Sensitivity of Solute-Transport Model to Data Uncertainty and Reliability of Simulated Results}

In any analysis, uncertainty in data accuracy is caused by errors in measurement, lack of needed information, and the inability to describe natural processes completely and accurately. For this study, several aquifer characteristics were unmeasured; therefore, uncertainty associated with their estimates is expected. The HST3D simulation that resulted from adjustments of estimates and values for aquifer properties and conditions is called the base simulation in the following discussion. The base-simulation results were variably sensitive to the uncertainties of each of the aquifer properties and characteristics and to the boundary conditions assumed for the analysis. The sensitivity of results of each property and condition can be tested, and the relative effects of data uncertainty on calculated results can be estimated (Konikow, 1978). A distinction was not made between the modular and the HST3D simulations in the following discussion of sensitivity, except for certain specifics, because the values used for aquifer properties and conditions in each simulation were similar.

The reliability of the base simulation was evaluated by testing the effect of data uncertainty on the simulated results for 1903-83. The aquifer properties and conditions that were taken from Meyer (1976) were not specifically tested for uncertainty. Nevertheless, a qualitative estimate of the reliability can be made on the basis of changes in the specifications for aquifer properties and conditions made during the various simulations. In some instances, when the specifications for a particular aquifer property or condition were changed, an effort was made to readjust 
other properties, within the limits of uncertainty, to achieve a satisfactory fit of the simulated results to the observed conditions. This process indicates the relative interdependence of the data uncertainties associated with the aquifer properties and conditions.

Aquifer properties and boundary conditions were tested using the modular model to determine the sensitivity of simulated head and water fluxes to data uncertainty. Most of these tests indicated that the head and water fluxes were relatively insensitive to changes in the aquifer properties and boundary conditions. The HST3D simulation was used to test the sensitivity of simulated concentrations and mass fluxes to data uncertainty.

The differences between the estimated predevelopment water table and the simulated predevelopment water levels for node-layers A and B is shown in figure 18. This comparison was made because measured water levels at depth for predevelopment conditions were not available and because the conditions at depth throughout most of the study area were likely at or nearly hydrostatic. If hydrostatic conditions had prevailed prior to development, the water levels in all node layers would be similar to the water table. An upward gradient under the river alluvium was assumed; therefore, a negative "error" in node-layer B would be expected where it underlies the river alluvium.

The simulated water levels are not exact duplicates of the estimated water table because of errors in estimating the water table, errors in the distribution of simulated aquifer properties and conditions, and uncertainties of grid spacing. Figure 18 shows that there are some areas where the simulated water levels did not match the estimated water table, but the errors were within the uncertainty of the estimates and available data, except in nodelayer $B$ beneath the river alluvium. The mean difference, the sum of the squared differences, and the mean-square difference between estimated and simulated water levels for predevelopment conditions in node-layers A and B are listed in table 3 . The 298 active nodes in each layer were weighted equally to avoid overemphasizing the large cells where little or no data were available.

The hydraulic gradient from node-layer A to node-layer B for simulation of predevelopment conditions is shown in figure 19. The negative "error" in figure 18 in the river alluvium area shows there was an upward (negative) gradient. The predevelopment hydraulic gradient from the bolson deposits under the river alluvium to the water table in the alluvium was assumed to be $10 \mathrm{ft}$ or more. However, a gradient of 3 to $4 \mathrm{ft}$ was the largest that could be simulated by the HST3D model, unless the ratio of horizontal to vertical permeability was increased to much greater than 1,000:1. Increasing this ratio was considered unrealistic, so the small gradient of 1 to $3 \mathrm{ft}$ was accepted as representative of predevelopment conditions. The simulated water levels for node-layers C, D, and E were all within $3 \mathrm{ft}$ of the overlying node-layer B simulated water levels and are not shown.

The differences between observed January 1984 water levels in the Hueco bolson aquifer (under water-table conditions) and the simulated water levels for December 1983 in node-layers A and B are shown in figure 20. The mean difference, sum of squared differences, and mean-square difference between observed (January 1984) and simulated (December 1983) water levels are listed in table 4. The January 1984 observed water levels were used to compare node-layers A and B because much the Hueco bolson aquifer is nearly vertically hydrostatic throughout most of the study area.

Node-layers A and B have substantially different simulated water levels for the river alluvium. Not all of this difference is caused by an upward hydraulic gradient. Water levels in node-layer B declined more than those in node-layer A in areas where the Rio Grande is not lined. Measured water levels just north of the Rio Grande do not represent the true water table because the well screens do not intersect a free-surface boundary. Therefore, water levels simulated for node-layer B are more representative of the water table in this area than are water levels simulated for node-layer A. The water levels for node-layer A in this area should be slightly higher than the observed water levels or the water levels simulated for node-layer B (fig. 19).

The differences between the observed and simulated water levels for node-layer B are smaller than those for node-layer A in the river alluvium area (fig. 20) directly north of Ciudad Juarez. Because this reach of the Rio Grande is lined, little recharge occurs from the river to node-layer A. Although the amounts of drawdown are different, the simulated water levels for node-layers A and B are similar to the observed water table in this reach. 


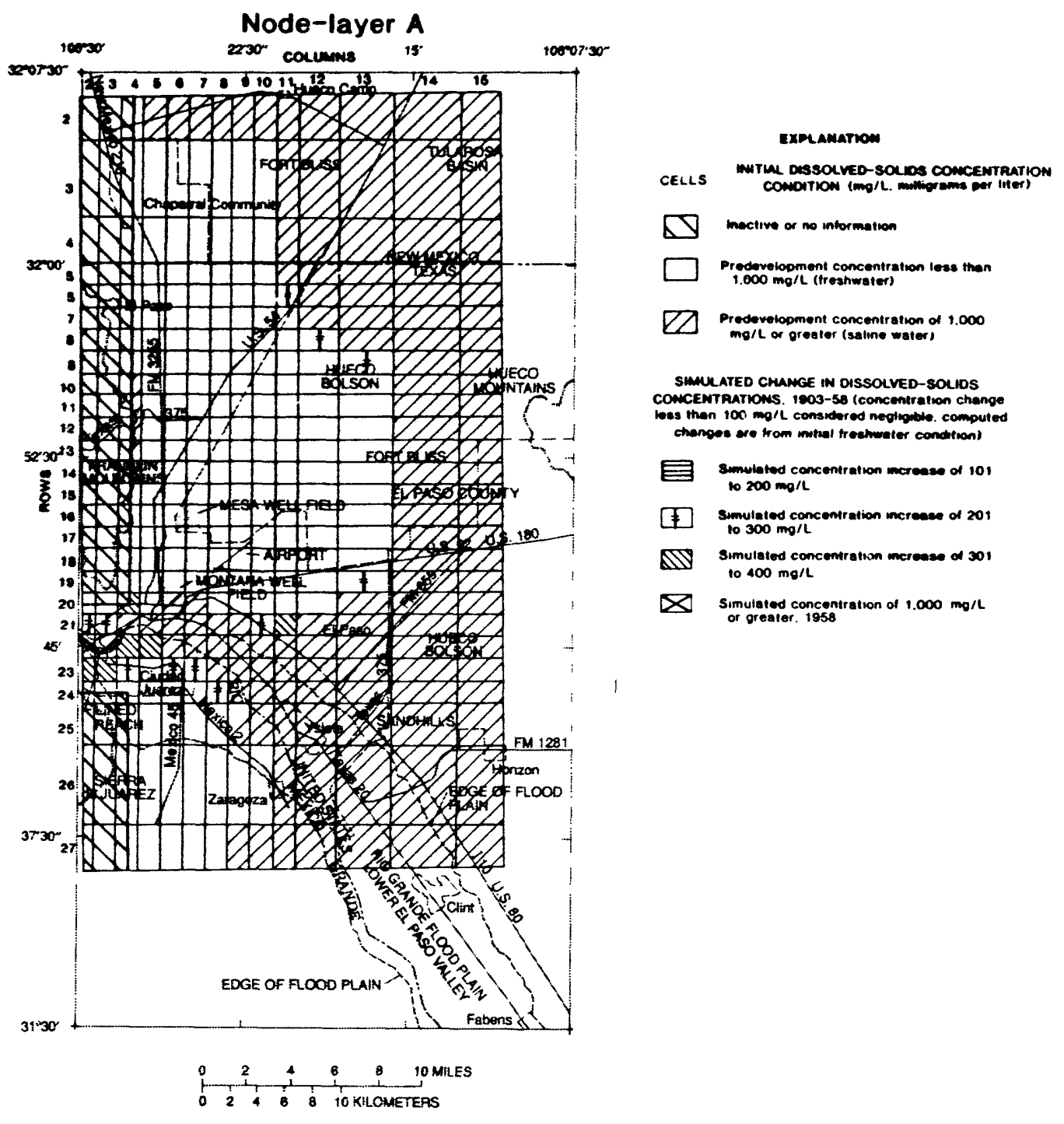

Figure 17. Simulated changes in dissolved-solids concentrations for $1903-58$ in node-layers $A, B$, and $C$ of the Hueco bolson aquifer. 

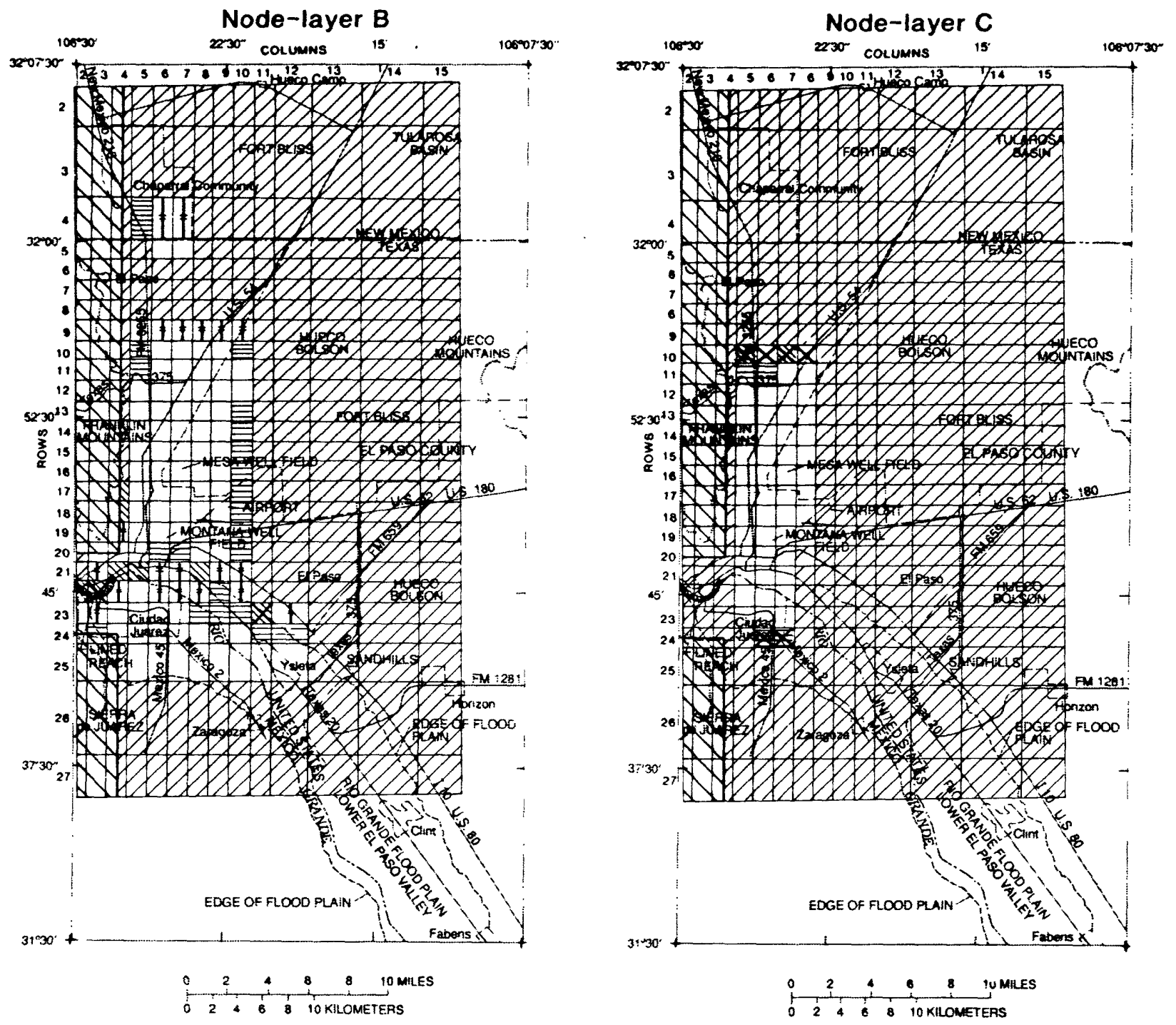

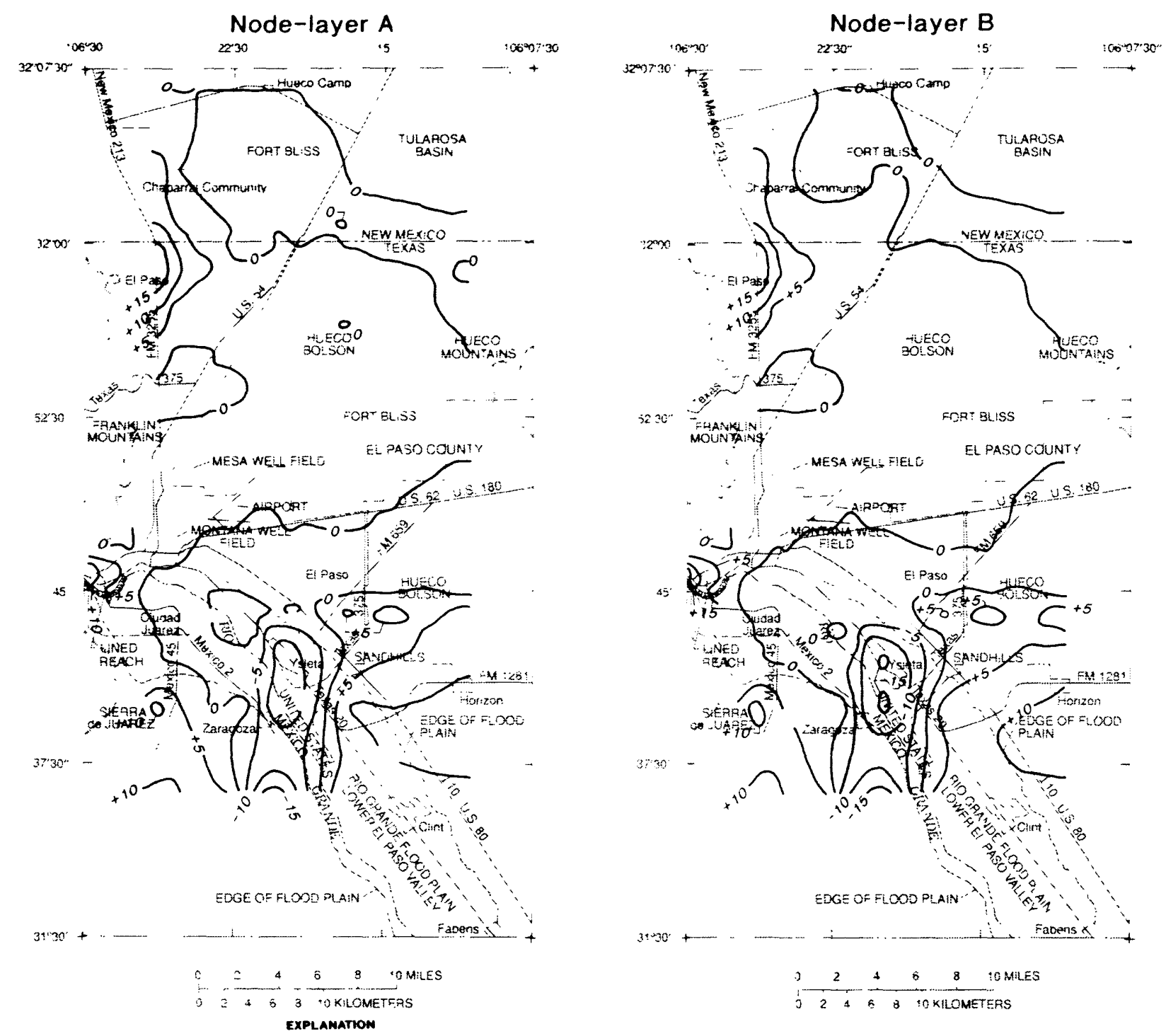
- $+5-$ LINE OF EOUAL DIFFERENCE BETWEEN ESTIMATED AND SIMULATED WATER LEVELS--interyal 5 teet Negative sign (-) indicates simulated water level is too high. positive $(t)$ indicates simulated water level is too tow

Figure 18. Differences between estimated predevelopment water table in the Hueco bolson aquifer and simulated predevelopment water levels for node-layers $\mathrm{A}$ and $\mathrm{B}$. 


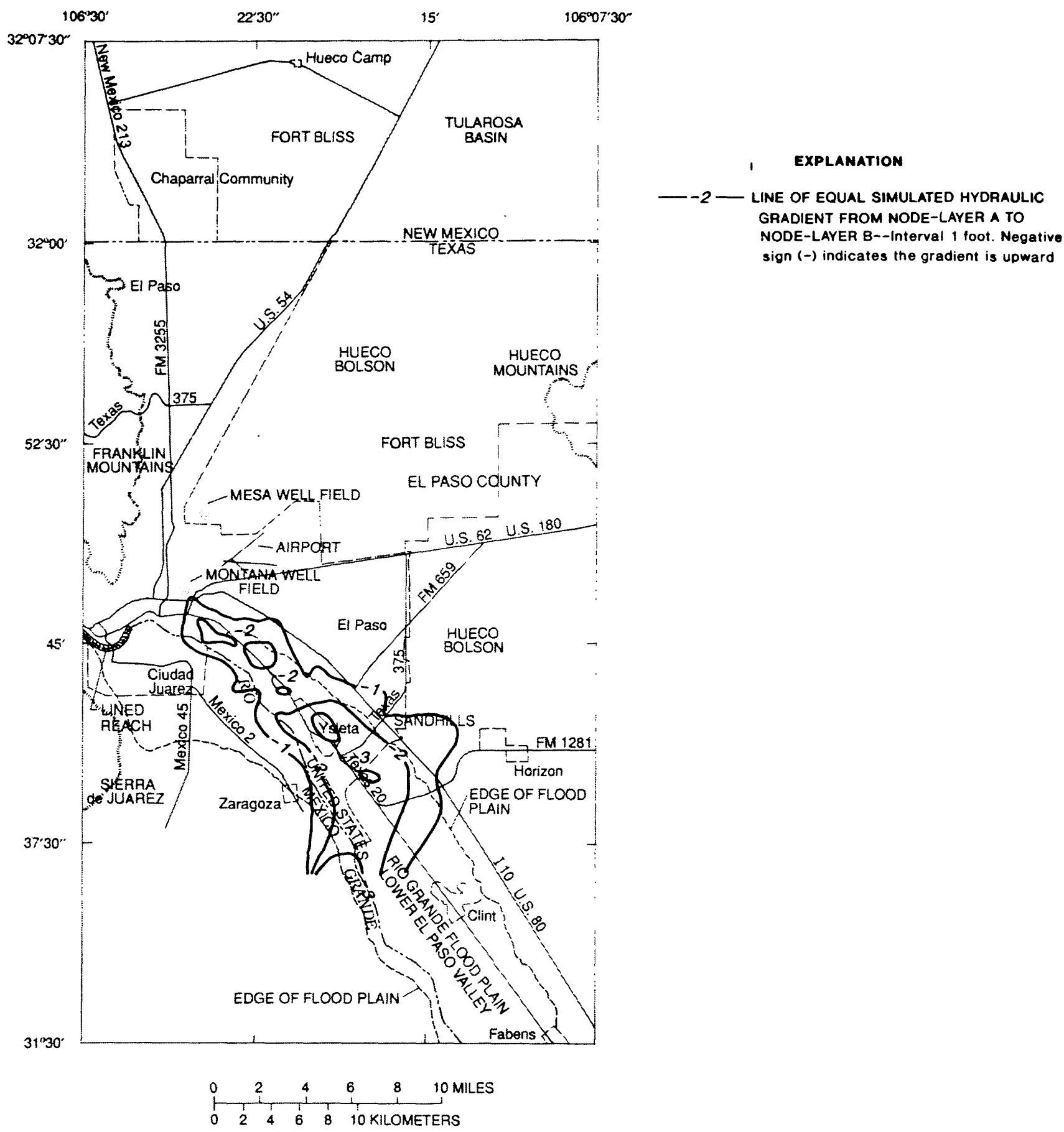

Figure 19. Hydraulic gradient from node-layer $A$ to node-layer $B$ for simulation of predevelopment conditions in the Hueco bolson aquifer. 


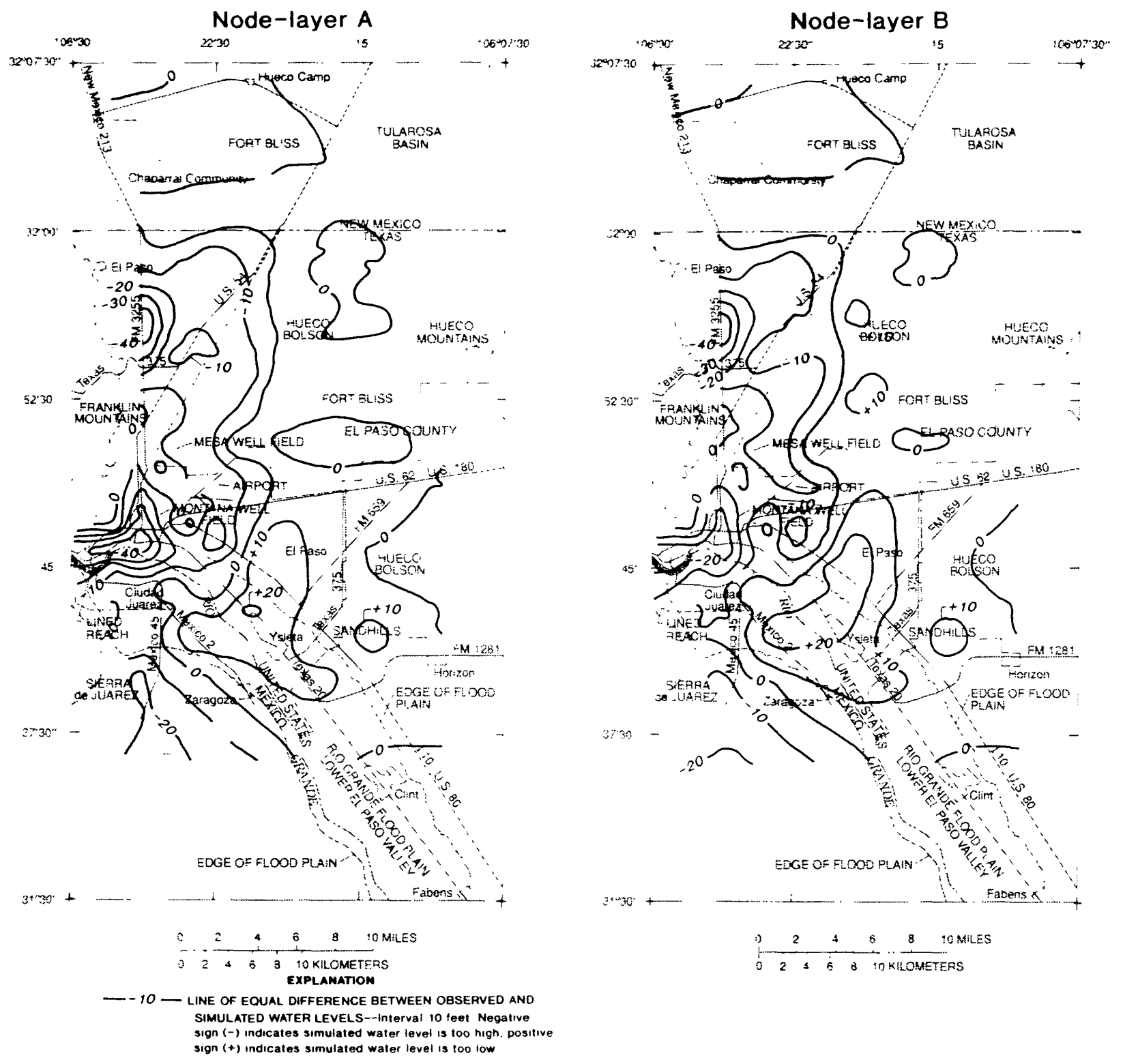

Figure 20. Differences between observed January 1984 water levels in the Hueco bolson aquifer and simulated water levels for December 1983 in node-layers A and B. 
Table 3. Summary of errors between estimated predevelopment water levels in the Hueco bolson aquifer and simulated predevelopment water levels in node-layers $A$ and $B$ of the ground-water flow and solute-transport model

$\left[\mathrm{ft}\right.$, foot; $\mathrm{ft}^{2}$, foot squared]

\begin{tabular}{cccc}
\hline $\begin{array}{c}\text { Node } \\
\text { layer }\end{array}$ & $\begin{array}{c}\text { Mean difference between estimated } \\
\text { predevelopment water levels and } \\
\text { simulated predevelopment water levels } \\
(\mathbf{f t})\end{array}$ & $\begin{array}{c}\text { Sum of squared } \\
\text { differences } \\
\left(\mathrm{ft}^{2}\right)\end{array}$ & $\begin{array}{c}\text { Mean square } \\
\text { difference } \\
\left(\mathrm{ft}^{2}\right)\end{array}$ \\
\hline $\mathrm{A}$ & 1.3 & 5,458 & 18.3 \\
$\mathrm{~B}$ & 1.4 & 6,138 & 20.6 \\
\hline
\end{tabular}

${ }^{1}$ Based on 298 active nodes per layer.

Table 4. Summary of errors between observed January 1984 water levels in the Hueco bolson aquifer and simulated December 1983 water levels in node-layers A and B of the ground-water flow and solute-transport model $\left[\mathrm{ft}\right.$, foot; $\mathrm{ft}^{2}$, foot squared]

\begin{tabular}{cccc}
\hline $\begin{array}{c}\text { Node } \\
\text { layer }\end{array}$ & $\begin{array}{c}\text { Mean difference between observed } \\
\text { and simulated water levels }\end{array}$ & $\begin{array}{c}\text { Sum of squared } \\
\text { differences } \\
\left(\mathbf{f t}^{2}\right)\end{array}$ & $\begin{array}{c}\text { Mean square } \\
\text { difference } \\
\left(\mathbf{f t}^{2}\right)\end{array}$ \\
\hline $\mathrm{A}$ & -5.7 & 50,604 & 170 \\
$\mathrm{~B}$ & -2.0 & 39,835 & 134 \\
\hline
\end{tabular}

${ }^{1}$ Based on 298 active nodes per layer.

Leakage into the aquifer from the oxidation lagoons, located north of El Paso, has formed a water-table mound underneath the lagoons (White, 1983, fig. 30). The mound does not appear in water levels simulated for nodelayer B.

In addition to the areas previously discussed, figure 20 shows large areas where the simulated water level is higher than the observed water levels by 10 to $20 \mathrm{ft}$ or more. This is partly the result of the relatively uniform (simplified) freshwater-zone transmissivity and also the result of the coarse spatial grid and combining of wells required by the grid. The actual drawdown in wells would be greater than the simulated decline in water levels because the simulated water level is an average for the cell in which a well is located. Meyer (1976) noted, on the other hand, that observation wells in the area tend to fill with silt and become less responsive to changes and, therefore, might not be representative. Finally, water-level measurements were made in December and January when wells are pumped the least, yet even during this period, many water levels might not be steady or truly representative of steady-state conditions. Considering the number of aquifer properties and conditions needed for the three-dimensional simulation and the availability of data, these errors are considered acceptable and no further changes to the HST3D simulation were made.

The simulated hydraulic gradient from node-layer A to node-layer B for December 1983 is shown in figure 21. Land and Armstrong (1985) indicated a downward gradient of 40 to $60 \mathrm{ft}$ near the Rio Grande where it is not 


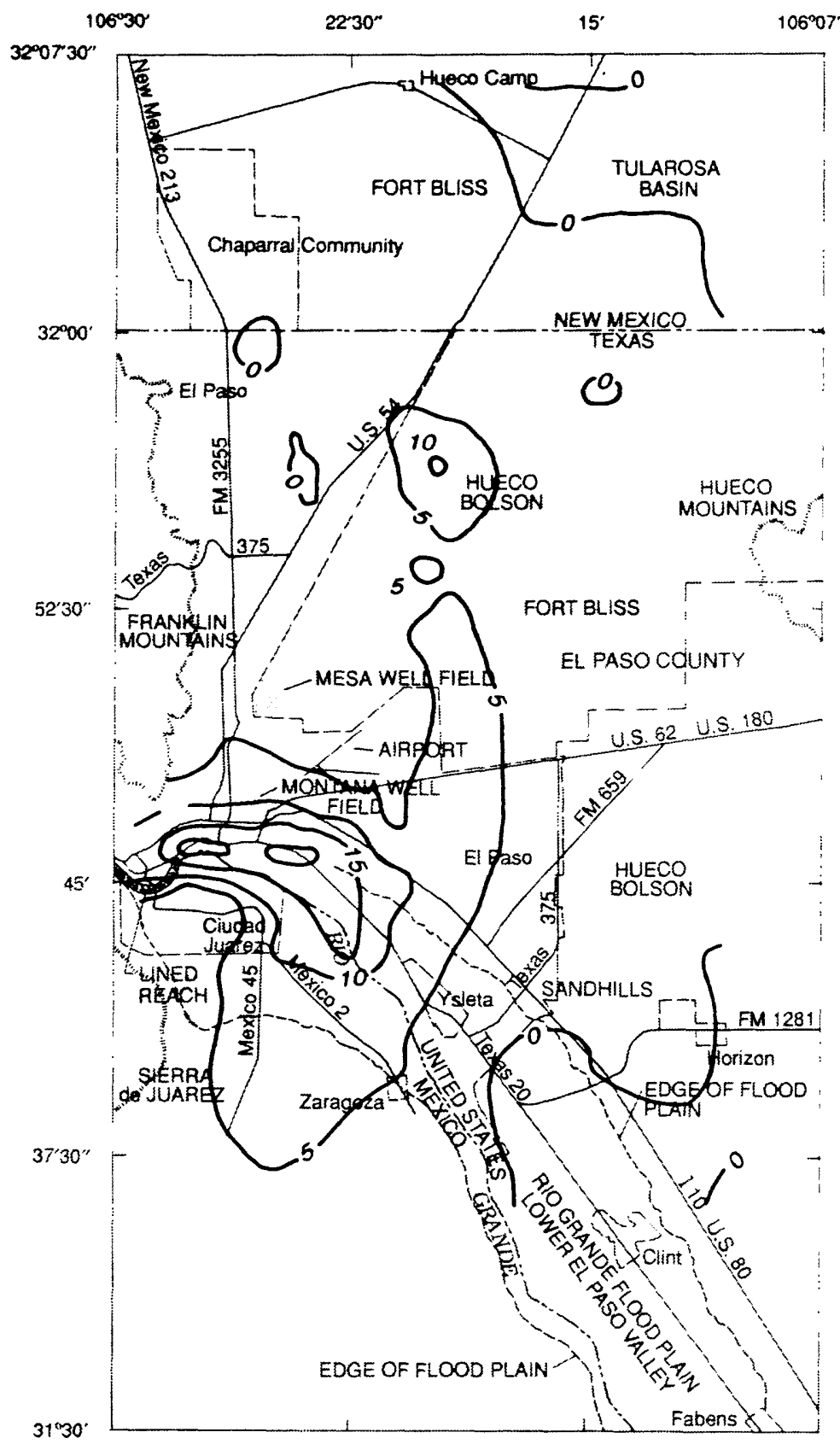

EXPLANATION

- 10 - LINE of EQUal Simulated hydraulic GRADIENT FROM NODE-A TO NODE-B-Interval 5 feet

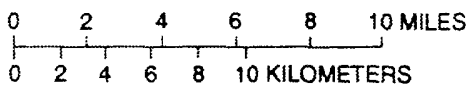

Figure 21. Hydraulic gradient from node-layer $A$ to node-layer $B$ for simulation of Hueco bolson aquifer conditions, December 1983. 
lined. The predevelopment gradient, estimated to be 3 to $4 \mathrm{ft} \mathrm{upward} \mathrm{from} \mathrm{the} \mathrm{bolson} \mathrm{deposits} \mathrm{to} \mathrm{the} \mathrm{river} \mathrm{alluvium,}$ reversed and increased downward during the historical period. The effects of leaky oxidation ponds northeast of El Paso, where there is an area of downward gradient, also is shown in figure 20. The reason for the arm-like feature curving northward from the river-alluvium area up toward the oxidation-pond area is unknown.

A test was conducted to evaluate the amount of error associated with use of a constant-pressure boundary in the HST3D simulation rather than a head-dependent flux boundary as in the modular simulation. The sensitivity of the simulated head inside the northern boundary of the model area and flow rates across that boundary were tested for a reasonable range of aquifer properties and conditions. The results indicated that the simulated head inside the model boundary was relatively insensitive to the northern boundary condition and that the flow rates varied relatively little and within the range of uncertainty of the data. Furthermore, only small changes in simulated head (less than $10 \mathrm{ft}$ ) and small changes in simulated flow rates (less than 20 percent) resulted when the boundary was changed from a head-dependent flux to a constant-pressure boundary.

A qualitative summary of the sensitivity of the simulated heads and dissolved-solids concentrations to the relative uncertainties in aquifer properties and conditions is shown in table 5. A summary of the sensitivity of simulated results to various numerical-simulation characteristics is shown in table 6.

Simulated head, dissolved-solids concentrations, or both, were most sensitive to the following aquifer properties, conditions, and methods (table 5):

1. Vertical hydraulic conductivity.

2. Distribution of river leakage in time and location.

3. Amount and areal pattern of ground-water withdrawals, particularly the vertical distribution of flow into a pumped well.

4. Methods used to calculate the drawdown caused by withdrawals (interference) between pumped wells.

Items 1 and 2 deal with aquifer properties or conditions that have substantial effects on the simulated results, and items 3 and 4 deal mainly with the ability of the numerical simulation to calculate the flow system accurately and are discussed in the section "Simulation Characteristics." Of the four most sensitive items, only the amount and areal pattern of withdrawals are well known.

\section{Aquifer Properties and Conditions}

The two aquifer properties or conditions listed (table 5) as having substantial effect on simulated results-vertical hydraulic conductivity and distribution of river leakage--have been estimated by several researchers (Meyer and Gordon, 1972; Meyer, 1976; and Marston and Lloyd, 1985). The estimates ranged from $1.5 \times 10^{-12}$ to $1.5 \times 10^{-5}$ $\mathrm{ft} / \mathrm{s}$ for vertical hydraulic conductivity and from 7.2 to $26 \mathrm{ft}^{3} / \mathrm{s}$ for river leakage. In the HST3D simulation, river leakage primarily affected the flow-through volumes from the point of recharge to the point of discharge only in the top 50 to $100 \mathrm{ft}$ of the river alluvium and in node-layer A of the HST3D simulation but did not affect substantially the net leakage to the deeper layers. Much of the flow-through water volume was rejected to drainflow fairly close to the point where it recharged the aquifer. The spatial distribution of river leakage was fairly well defined, but additions from lawn irrigation and leaking oxidation lagoons have changed the overall distribution from steady state (White, 1983).

\section{Simulation Characteristics}

Values for simulated head and dissolved-solids concentrations are strongly dependent on how the withdrawals and the resultant head declines are calculated by the simulation. One of the unmeasured properties in the HST3D simulations was the effective radius of the wells; therefore, a test of the effect of varying the effective radius of the wells was conducted. The effective well radius calculated by the method of Bennett and others (1982) was compared to a test case where the effective well radius was increased by a factor of 10 . A factor of 10 might seem large, but 
Table 5. Summary of sensitivity of simulated head and dissolved-solids concentrations to data uncertainties

\begin{tabular}{|c|c|c|c|}
\hline $\begin{array}{l}\text { Aquifer property } \\
\text { or condition }\end{array}$ & $\begin{array}{c}\text { Quality of } \\
\text { available data }\end{array}$ & $\begin{array}{l}\text { Relative sensitivity } \\
\text { of simulated heads }\end{array}$ & $\begin{array}{c}\text { Relative sensitivity of } \\
\text { dissolved-solids concentrations }\end{array}$ \\
\hline \multicolumn{4}{|l|}{$\begin{array}{l}\text { Permeability } \\
\text { (or hydraulic } \\
\text { conductivity) }\end{array}$} \\
\hline Horizontal & Good & Small on a regional scale & Small on a regional scale \\
\hline Vertical & Poor & $\begin{array}{l}\text { Great with respect to vertical } \\
\text { flow and river leakage }\end{array}$ & $\begin{array}{l}\text { Great with respect to downward } \\
\text { flow near the river and upconing } \\
\text { under wells }\end{array}$ \\
\hline River leakage & Poor & Great & $\begin{array}{l}\text { Great with respect to downward } \\
\text { movement of water under the river }\end{array}$ \\
\hline $\begin{array}{l}\text { Specific yield and } \\
\text { storage coefficient }\end{array}$ & Poor & Moderate & Small \\
\hline Well pumpage & Excellent & Great & Great \\
\hline Interference between wells & Poor to nonexistent & Small except locally & Great with respect to upconing \\
\hline $\begin{array}{l}\text { Constant pressure at } \\
\text { southeastern corner of } \\
\text { model }\end{array}$ & Good & Small & Small \\
\hline $\begin{array}{l}\text { Constant pressure at } \\
\text { northern end of model }\end{array}$ & Good & Small except locally & Small \\
\hline Saline-water density & Poor & Small & Small with large vertical anisotropy \\
\hline
\end{tabular}

Table 6. Summary of sensitivity of simulated head and dissolved-solids concentrations to model characteristics

\begin{tabular}{llll}
\hline \multicolumn{1}{c}{$\begin{array}{c}\text { Model } \\
\text { characteristic }\end{array}$} & $\begin{array}{c}\text { Quality of } \\
\text { approximation of } \\
\text { actual hydrogeologic } \\
\text { system }\end{array}$ & $\begin{array}{c}\text { Relative sensitivity } \\
\text { of simulated head }\end{array}$ & $\begin{array}{c}\text { Relative sensitivity of } \\
\text { dissolved-solids } \\
\text { concentrations }\end{array}$ \\
\hline Spacing of horizontal grid & Fair & Small & Great for vertical gradient
\end{tabular}

\footnotetext{
${ }^{1}$ Necessary to represent the vertical gradient, but in this instance, smaller spacing of vertical grid probably would not increase accuracy.
} 
the equation used the natural logarithm of the value in the computation; thus, the effective well radius was changed by a large amount to create a discernible difference in the simulated heads. The comparison indicated that the simulated head near the wells was moderately sensitive to the effective well radius, but that the dissolved-solids concentration was relatively unaffected.

Upconing of saline water occurs when saline water beneath the well screen is drawn upward to the zone of low pressure created by the withdrawal of water. The head changes and saline-water movement caused by well withdrawals are sensitive to the method used to calculate the allocation of flow with depth into a well screen. Because the potential for saline-water movement in the study area is created by large withdrawals from wells, it is imperative that the three-dimensional flow of water to wells be simulated accurately.

A series of simulations were conducted to compare the effects of two methods of calculating the distribution of well-bore flow on the head and dissolved-solids concentrations in the Hueco bolson aquifer. Two additional series of simplified large-scale simulations were conducted to help understand what might occur near a well screen and in the surrounding aquifer material and also to understand the sensitivity of head and solute transport to various aquifer properties and conditions. These large-scale simulations were an attempt to determine, on a cursory level, the relative hydraulic gradients in three dimensions from the well to the aquifer and between aquifer layers, and to help understand the flow to a well screen from each layer. For all of these tests, well losses were assumed to be negligible.

The hypothetical flow system of these tests was based on a block of aquifer material (cell), similar to the Hueco bolson deposits, about $330 \mathrm{ft}$ long, $82 \mathrm{ft}$ wide, and $330 \mathrm{ft}$ deep. The block had one or two wells in it. Two opposite sides, the short dimension, were no-flow boundaries--as if image wells outside the block were the same distance from the no-flow boundaries as were the well or wells inside the block. The other lateral boundaries were constant pressure, based on hydrostatic conditions prior to pumping, and specified concentration nodes to simulate a saline-water layer beneath the well screens. The top boundary was a free surface, and the bottom boundary was a no-flow boundary in all but the last test case. The initial conditions in all were $328 \mathrm{ft}$ of freshwater hydrostatic head through the entire aquifer block. The dissolved-solids concentration was $500 \mathrm{mg} / \mathrm{L}$, except in node-layer $\mathrm{D}$ where the dissolved-solids concentration was $3,000 \mathrm{mg} / \mathrm{L}$.

Preliminary test simulations of the transient response of unconfined aquifer blocks indicated that the watertable layer of the simulation yielded the bulk of the water to a well screen, but the relative yield decreased as steadystate conditions were approached. The transient response of unconfined aquifers is not well understood, and the results of these preliminary simulations indicated that simulating this process is not straightforward. Simulating the transient response of aquifers to pumped wells was beyond the scope of this report and was not considered in the test simulations.

All well-test simulations were conducted for 116 days. This time frame was more than sufficient in all cases for steady-state conditions to develop for modular and HST3D simulations. Most of the test cases also were conducted for 1,160 days and produced results with negligible differences from the 116-day results.

The spacing of discrete nodes used in well-test simulations ( 21 columns, 6 rows, and 11 node layers) was a compromise based on available computer time and space, and the need to obtain results for a number of computer simulations in a timely manner. Each of these test simulations was almost as large, in terms of computer use, as the regional simulation of the entire aquifer, but the test simulations were made for a much shorter time period. Each test simulation required 6 to 12 hours to complete on a Prime 9955 computer. Preliminary test simulations were done using finer vertical spacing ( 21 and 41 node layers), and the results of the finely spaced simulations showed no substantial differences in either flow or transport from the 11-layer simulation. The situations that were simulated were one multilayer well in a finite block of aquifer with water-table decline and a constant-pressure boundary for water sources, and two multilayer wells in a finite block of aquifer with the same sources of water. One well was considered to be pumped from all layers and the other from only the bottom half of the node layers or one-half the vertical thickness of the aquifer.

The plots in figure 22 show results of pumping two wells in an aquifer that has a vertical intrinsic permeability 1,000 times less than the horizontal permeability. The plot using the standard method (McDonald and Harbaugh, 

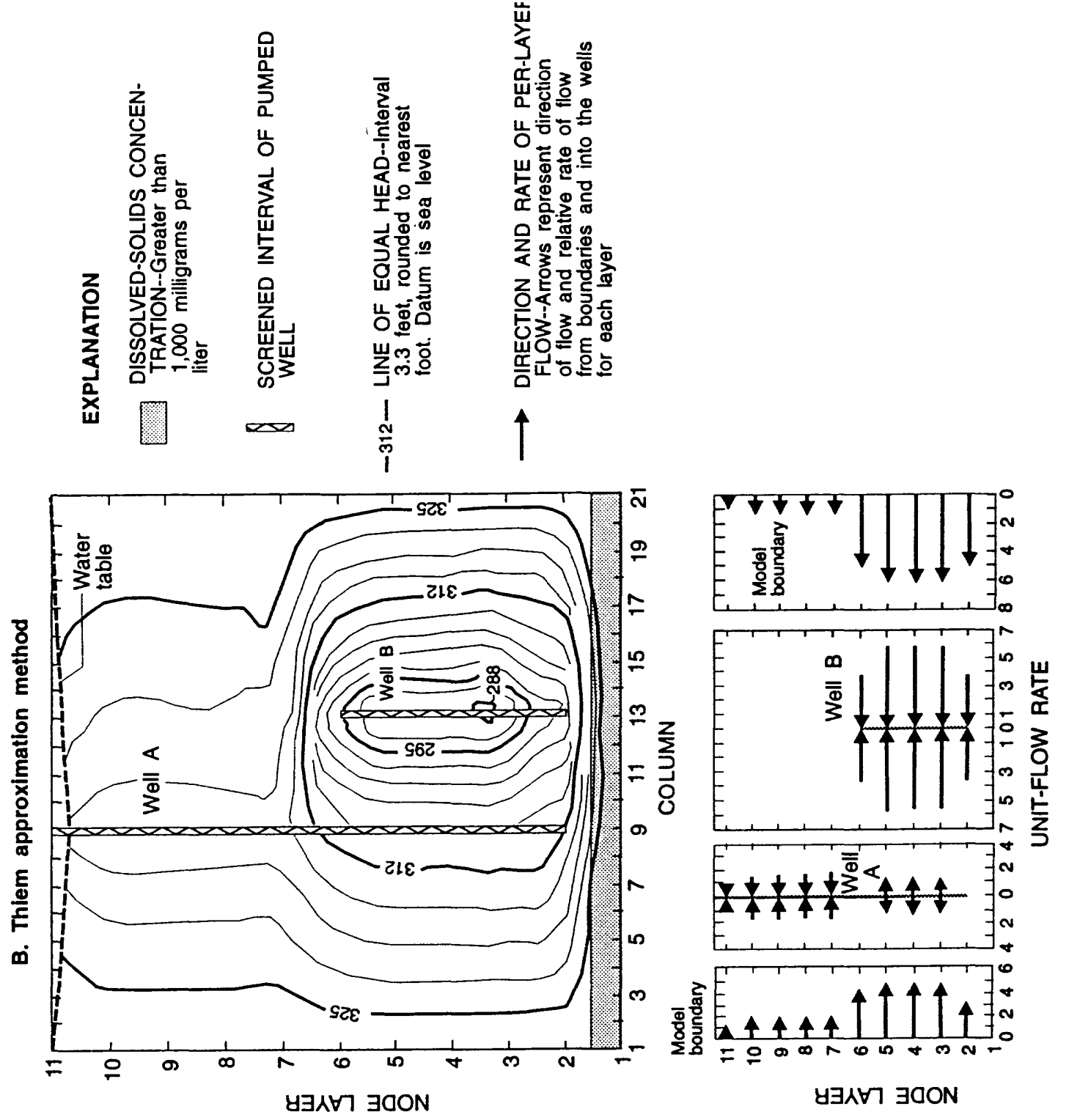

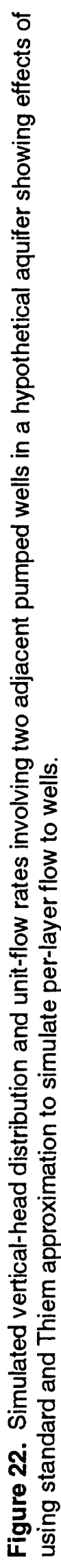

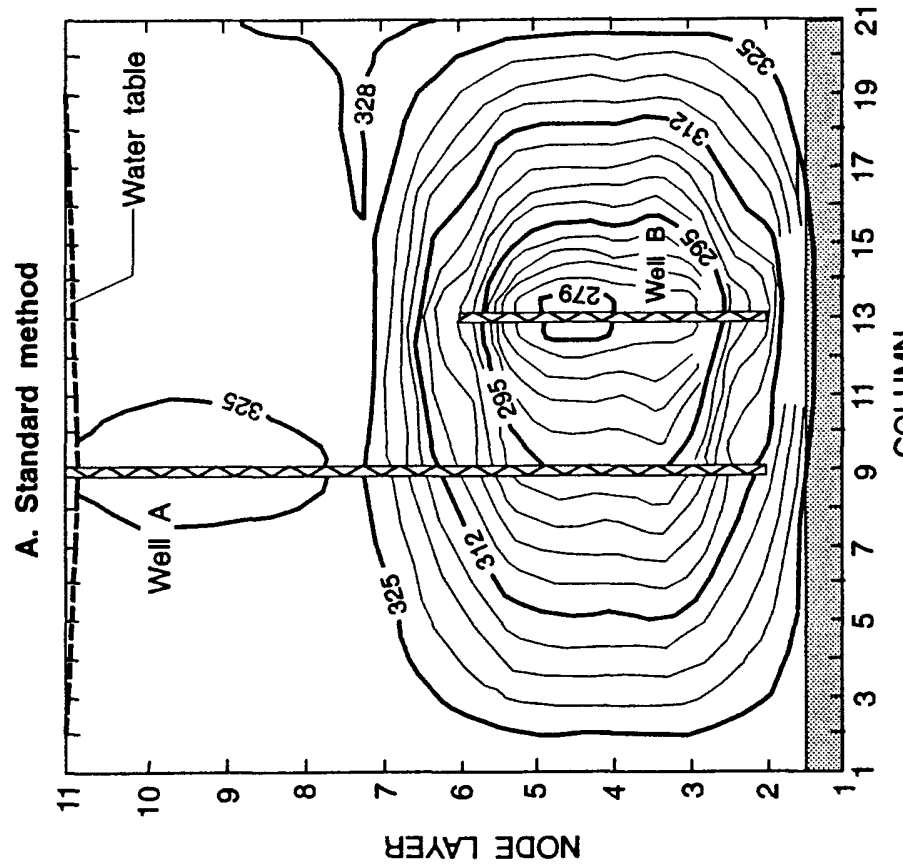


1988) shows the results of allocating per-layer well flow by specifying the amount of flow from each node layer on the basis of the transmissivity of that layer. The second plot in figure 22 shows the results using the Thiem approximation method of the HST3D simulation, as defined in the section "General description of solute-transport model." The top half of each plot shows the head (water table) and position of the saline water (dissolved-solids concentration greater than $1,000 \mathrm{mg} / \mathrm{L}$ ) in a cross section through the hypothetical aquifer and the wells. The bottom half of each plot shows the relative rates of flow per layer into or from each well and from the layers of boundary nodes on the sides of the hypothetical aquifer. The results are for steady-state conditions of flow and transport.

The differences between the two potential fields shown in the plots are substantial. The water table resulting from use of the standard method (maximum decline about $4 \mathrm{ft}$ ) was not drawn down nearly as much as the water table resulting from the Thiem approximation method (maximum decline about $11 \mathrm{ft}$ ). The head at depth in the aquifer decreased more when the standard-method simulation (minimum head about $279 \mathrm{ft}$ above datum) was used than when the Thiem approximation-method simulation (minimum head about $288 \mathrm{ft}$ above datum) was used. The downward hydraulic gradient was steeper in the standard-method simulation results (about $0.47 \mathrm{ft} / \mathrm{ft}$ ) than in the Thiem approximation-method simulation results $(0.32 \mathrm{ft} / \mathrm{ft})$.

A comparison of the relative per-layer flow rates into the wells shows that the Thiem approximation method of the HST3D simulation tended to distribute the flow and the head decline over a much larger, primarily vertical zone than did the standard method. Because the pumping rate of well B (the deep short-screen well) was about five times that of well A (the long-screen well) in the hypothetical case shown and by virtue of the large ratio of horizontal to vertical intrinsic permeability, the Thiem approximation method induced slight reverse circulation in well A, causing water to flow from well A into the aquifer.

A comparison of the relative fluxes from the constant-pressure boundaries shows distinct differences in the vertical distribution of flow into the hypothetical block of the aquifer. If the boundaries had been simulated at a large distance, the vertical variability in fluxes from these boundary nodes would not have been as great. The lines of equal head probably would have been spread out more laterally if the constant-pressure boundaries were farther from the wells. Having the boundary nodes close to the well screen illustrates the dominance of lateral flowpaths near the well over vertical flowpaths in the aquifer.

Wells that have the exact pumping characteristics and well-construction characteristics of these hypothetical wells probably do not exist. However, this hypothetical situation shown in figure 22 is sufficiently similar to conditions in the Hueco bolson aquifer to make the results discussed here likely. The primary purpose of comparing these two simulation results was to demonstrate the sensitivity of the simulated head and dissolved-solids concentration near a pumped well to the sensitivity of the method used in the simulation for calculating the effects of withdrawals on the aquifer.

The differences in the results of the two methods of allocating well flow by layer are especially important for the simulation of the upconing of saline water. Although this particular (hypothetical) aquifer and well system (using an anisotropy ratio of 1,000:1) indicated no upconing of saline water, the method used to calculate withdrawals in the simulation could affect the solute transport where wells affect the head at depth. In all the regional simulations and in the following test simulations of the hypothetical aquifer, the Thiem approximation method was used because it calculates per-layer well flow on the basis of transmissivity and the head in the aquifer some distance from the well. Therefore, the Thiem approximation method can more accurately calculate the effects of well withdrawals on the head and dissolved-solids concentration in the aquifer simulation than can the standard method for allocating per-layer well flow.

The flow system of an aquifer is affected by withdrawals of municipal and other large-volume water-supply wells. Accordingly, the local and regional aspects of well-withdrawal hydraulic characteristics are important in the movement of saline water. The understanding of the interaction of wells with each other and the accuracy of the simulated head and solute transport are affected by the depth of withdrawal from the aquifer and the dynamics of flow from the aquifer into the well screens. Unfortunately, little is known about the complex interactions of wells in a water-table aquifer. Numerical simulations (assuming the model can accurately simulate the water flow near wells) 
Table 7. Properties and conditions that were held constant in the well-test simulations

\section{Property or condition}

Measurements and times

Well diameter 1.0 foot

Number of nodes in the $\mathrm{x}$-direction

21 columns

Number of nodes in the y-direction

6 rows

Number of nodes in the z-direction

11 layers

Spacing of nodes in the $\mathrm{x}$-direction

16.4 feet

Spacing of nodes in the $y$-direction

16.4 feet

Spacing of nodes in the $\mathrm{z}$-direction

32.8 feet

Open interval of well A, layers (numbered from bottom up)

$2-11$

Open interval of well B, layers (two-well simulations only)

2-6

Fluid compressibility

$3.0769 \times 10^{-6}$ pound per square inch

Medium compressibility

$2.679 \times 10^{-8}$ pound per square inch

Fluid viscosity

1.00 centipoise

Effective porosity, also specific yield

0.20

Initial hydrostatic potential

328 feet above datum

Boundary node potential

Horizontal intrinsic permeability

Minimum length of time step

hydrostatic (328 feet above datum)

$10.7 \times 10^{-7}$ foot squared

1.0 second

Maximum length of time step

Single-well tests

10,000 seconds

Two-well tests

100,000 seconds

Total pumping rate

Single-well tests

1.13 cubic feet per second

Two-wells tests

2.18 cubic feet per second

Time period simulated

116 days

can help in understanding the sensitivity of simulated head and solute concentrations to the construction and operation of long-screen wells, aquifer properties, and boundary conditions.

The results of five single-well test simulations are shown in figure 23. Saline water is indicated in the results illustrated by the shaded areas. The contours of equal head in the illustrations are based on the pressure at the node divided by the average density for the node plus the altitude of the node. The heads derived do not necessarily indicate the actual gradient of flow. The importance of these illustrations is to show the steady-state head and the distribution of solute.

Although none of the test simulations was based on actual field conditions, aside from aquifer properties and scale of the problem, the simulations do represent a range of plausible conditions that could exist in the Hueco bolson aquifer. Properties and conditions that were held constant through all the well-test simulations are listed in table 7. The first series of well-test simulations represented a condition similar to that at one of the municipal wells 
in the study area that is fully screened through the freshwater part of the aquifer (fig. 23). The properties and conditions that were varied in this single-well series of simulations are given in table 8 .

Test case I shows the effect of isotropic intrinsic permeability on the potential head and on saline-water movement. Some upconing is shown in the results of test case I. Test case II shows the results of isotropic intrinsic permeability where the water density is equal to that of seawater $\left(64.00 \mathrm{lb} / \mathrm{ft}^{3}\right.$ at $\left.25^{\circ} \mathrm{C}\right)$. In the Hueco bolson aquifer, the saline-water density in the vicinity of the freshwater is about $62.60 \mathrm{lb} / \mathrm{ft}^{3}$ at $25^{\circ} \mathrm{C}$, but seawater density was used in test case II to represent the largest possible density difference. Upconing is indicated in these results, but the intrusion has a smaller cross-sectional area than that for test case I. The main difference in simulated head is in the lowest layer of saline water.

Test case III (fig. 23) is similar to test case II, except that the vertical permeability is 100 times smaller than the horizontal permeability. The ratio of horizontal to vertical intrinsic permeability of 100:1 is considered representative of the Hueco bolson aquifer at the scale of this hypothetical aquifer block. The difference between test cases II and III is the lower head around the well screen and the much smaller zone of intrusion of saline water in test case III (fig. 23). Test case IV shows the results of a simulation that was similar to test case III, except the anisotropy ratio was 1,000:1. The main difference between test cases III and IV is the lack of any saline-water intrusion around the well screen in test case IV. The final test case of the single-well tests (V) is similar to test case IV except that the density of the saline water was reduced to $62.60 \mathrm{lb} / \mathrm{ft}^{3}$ (table 8), which is the density of saline water expected in the aquifer. Upconing did not occur under these conditions.

Large variations occurred in the simulated vertical velocities listed in table 8 , but the horizontal velocities generally were consistent among the five test simulations. The maximum vertical velocities always were located in the cell directly below the bottom of the simulated well screen. A comparison of test cases I and II (the isotropic cases) shows that the difference in density had only a slight effect on the minimum head near the well screen and little effect on the maximum-vertical velocity. A comparison of test cases IV and V (the most anisotropic cases) shows that the difference in density did have a substantial effect on the maximum-vertical velocity, but upconing of saline water did not occur in either case.

The next series of well-test simulations was similar to the first series except that two wells were simulated. The properties and conditions that were varied in the two-well test series are listed in table 9. The relative rate of flow per layer into the well screens and from each layer of boundary nodes and the heads around the wells are shown in figure 24. Well A had a long screen similar to those in the single-well test simulations. Well B was screened only in the lower half of the freshwater section of the hypothetical aquifer block. This two-well test series was conducted to evaluate the effects of anisotropy, relative withdrawal rates from each well, and boundary conditions at the mutual interference between the two wells and the resultant effects of the interference on saline-water movement.

Test case I in the two-well test simulations (fig. 24) shows the result of two wells pumped under isotropic conditions with about five times as much withdrawal from well B (short-screen well) as from well A (long-screen well). The results indicate substantial upconing of saline water, especially around well B. Small vertical gradients were evident downward from the water table and upward from the saline-water layer to the well screens.

Test case II (fig. 24) shows the effects of identical conditions (to test case I) except that the vertical permeability was one-tenth the horizontal permeability. The results indicate greater vertical gradients downward from the water table but less upward movement of saline water. The lateral extent of saline-water intrusion also was greater in test case II than in test case I. The arrows indicating relative magnitude and direction of flow show that the lower head in well B (short-screen well) induced reverse flow in well A (long-screen well) in the test case II results. If the condition of reverse flow in a well bore were to take place in the Hueco bolson aquifer (test case II), it would have a substantial effect on the dissolved-solids concentrations in the water from both wells. Because of reverse circulation, well A would take in more water than it would yield at land surface. It also would draw most of the water from the top half of the aquifer. Water from well A would have relatively small dissolved-solids concentrations. Increased salinity of well A discharge water would not be evident unless well B was not pumping; then water could flow into well $\mathrm{A}$ from the entire thickness of the aquifer. Because it would be drawing water that is relatively fresh into the 

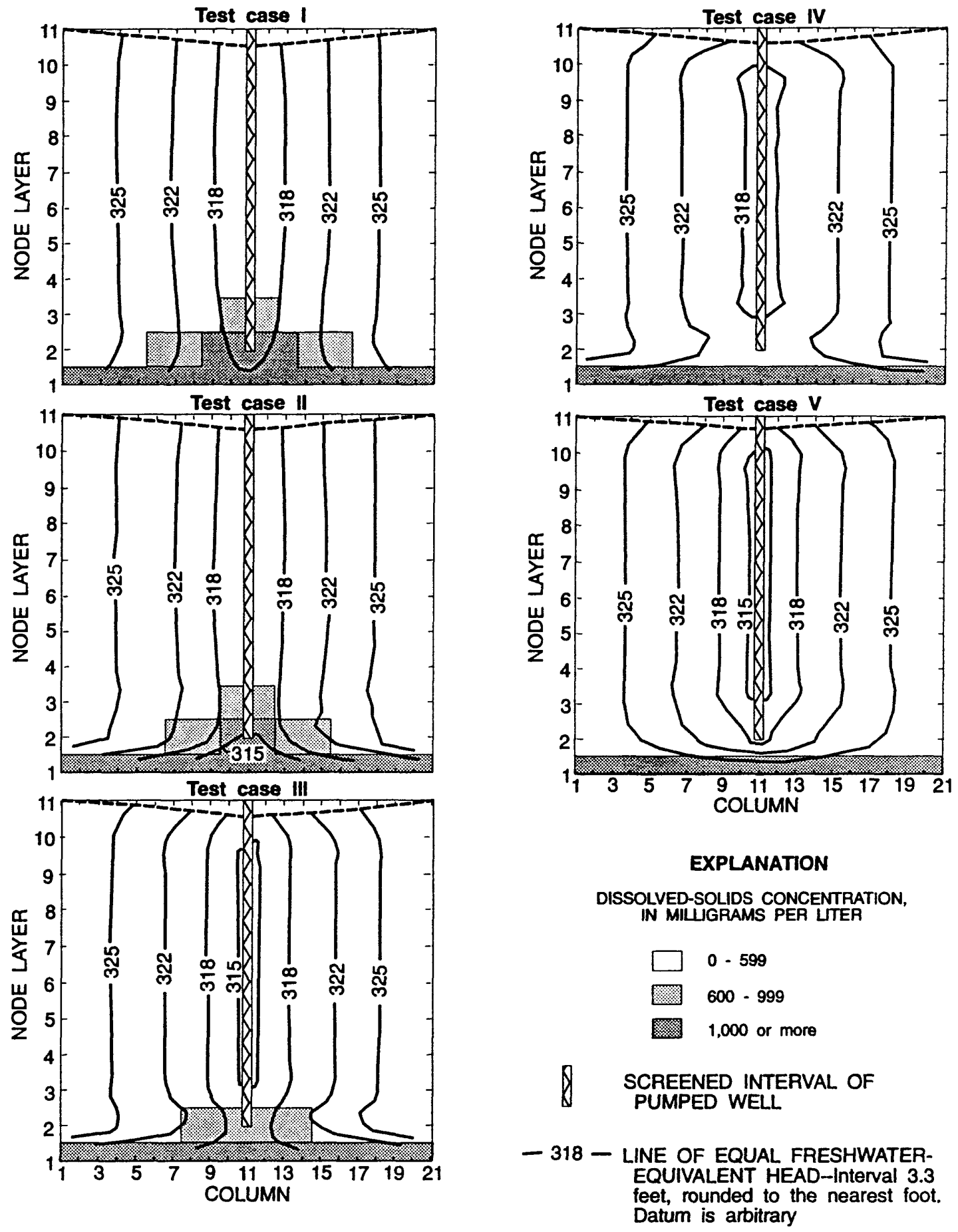

- WATER TABLE

Figure 23. Simulated vertical-head and dissolved-solids concentration distributions and unit-flow rates involving one pumped well in a hypothetical aquifer showing effects of fluid density and ratio of horizontal to vertical aquifer permeabilities on potential upconing of saline water. 
Table 8. Properties and conditions that were varied in and results from the single-well test simulations shown in figure 23

\begin{tabular}{|c|c|c|c|c|c|}
\hline \multirow{2}{*}{ Property or condition } & \multicolumn{5}{|c|}{ Test case } \\
\hline & 1 & II & III & IV & $\mathbf{v}$ \\
\hline $\begin{array}{l}\text { Ratio of horizontal-to-vertical } \\
\text { intrinsic permeability }\end{array}$ & 1 & 1 & 100 & 1,000 & 1,000 \\
\hline Number of time steps & 43 & 43 & 60 & 128 & 155 \\
\hline $\begin{array}{l}\text { Density of saline water } \\
\text { (pounds per cubic foot) }\end{array}$ & 62.60 & 64.00 & 64.00 & 64.00 & 62.60 \\
\hline \multicolumn{6}{|l|}{ Results: } \\
\hline $\begin{array}{l}\text { Minimum head } \\
\text { (feet above datum) }\end{array}$ & 314 & 313 & 318 & 314 & 314 \\
\hline $\begin{array}{l}\text { Maximum vertical velocity } \\
\left(\text { feet per second } \times 10^{6} \text { ) }\right.\end{array}$ & 140 & 137 & 4.82 & .166 & .574 \\
\hline $\begin{array}{l}\text { Maximum horizontal velocity } \\
\left(\text { feet per second } \times 10^{6}\right)\end{array}$ & 320 & 317 & 306 & 304 & 304 \\
\hline
\end{tabular}

aquifer through well A, well B might not yield water as saline as might be expected, but saline-water intrusion still would be apparent. Even when well A was not pumping, freshwater still would be drawn down into the lower half of the aquifer by well B through well A. If the positions of the saline water and freshwater were reversed (saline water overlying freshwater), such as under the river alluvium, the deep short-screen well would draw saline water down into the freshwater zone through a similar long-screen well.

Test case III in the two-well test simulations (fig. 24) was similar to test case II, except that the vertical intrinsic permeability was 100 times smaller than the horizontal intrinsic permeability. The head distribution around the wells was only slightly different than in test case II, and the relative rates of flow per layer showed a similar pattem, including flow reversal in well A (long-screen well). The most important difference was that saline-water intrusion did not occur in test case III.

Test case IV was similar to test case III, but the ratio of horizontal to vertical intrinsic permeability was 1,000:1, as used in the regional aquifer simulation. The results of test case IV indicated no substantial difference from the results for case III either in head, rates of flow per layer, or in saline-water movement; therefore, results of test case IV are not shown in figure 24.

Test case V (fig. 24) had all the same properties and conditions of test case IV, except that the withdrawal was divided equally between both wells. Total well withdrawal was the same as in the rest of the two-well test simulations. Results from test case $V$ show that the head distribution around the two wells was substantially different than in the other test cases, and no reverse flow was induced in well A (long-screen well). Because of the relatively small vertical permeability, saline-water upconing still did not occur.

Results of test case VI of the two-well test simulations were identical to those of test case III. In this test, all aquifer properties and conditions were the same as for test case IV, except that the lowermost layer of nodes had constant pressure and specified concentrations. This test resulted in the strongest upward gradient from the salinewater zone. However, as in test cases III and IV, there was no saline-water upconing into the freshwater zone. The vertical fluxes from the specified-pressure and concentration nodes were insignificant compared to the lateral fluxes, and the results of test case VI are not shown in figure 24. 
Table 9. Properties and conditions that were varied in and results from the two-well test simulations shown in figure 24

\begin{tabular}{|c|c|c|c|c|c|c|}
\hline \multirow{2}{*}{$\begin{array}{l}\text { Property or } \\
\text { condition }\end{array}$} & \multicolumn{6}{|c|}{ Test case } \\
\hline & $\mathbf{I}$ & II & III & IV & $\mathbf{v}$ & VI \\
\hline $\begin{array}{l}\text { Ratio of horizontal-to-vertical } \\
\text { intrinsic permeability }\end{array}$ & 1 & 10 & 100 & 1,000 & 1,000 & 1,000 \\
\hline Number of time steps & 155 & 128 & 155 & 128 & 81 & 128 \\
\hline $\begin{array}{l}\text { Density of saline water } \\
\text { (pounds per cubic foot) }\end{array}$ & 62.60 & 62.60 & 62.60 & 62.60 & 62.60 & 62.60 \\
\hline \multicolumn{7}{|l|}{$\begin{array}{l}\text { Well-flow rate } \\
\text { (cubic feet per second) }\end{array}$} \\
\hline Long-screen well & .35 & .35 & .35 & .35 & 1.09 & .35 \\
\hline Short-screen well & 1.84 & 1.84 & 1.84 & 1.84 & 1.09 & 1.84 \\
\hline Bottom boundary conditions & (1) & (1) & (1) & (1) & (1) & (2) \\
\hline \multicolumn{7}{|l|}{ Results: } \\
\hline $\begin{array}{l}\text { Minimum head } \\
\text { (feet above datum) }\end{array}$ & 292 & 287 & 286 & 285 & 297 & 285 \\
\hline $\begin{array}{l}\text { Maximum vertical velocity } \\
\left(\text { feet per second } \times 10^{6}\right)\end{array}$ & 407 & 89.6 & 14.9 & 1.68 & 1.26 & 1.70 \\
\hline
\end{tabular}

\section{Dispersion}

Several factors affected the apparent dispersion of solute calculated by the HST3D simulation. One of these factors was related to the layered nature of the deposits that constitute the Hueco bolson aquifer. Because the relatively small hydraulic conductivity of the clay layers was not represented explicitly, this lack of detail in the simulation increased the apparent dispersion of the solute concentrations. Guven and others (1984) showed that a lack of detailed information on the vertical distribution of hydraulic conductivity affects the distribution of flow velocities and the resultant convective transport. Sudicky and others (1985) showed that diffusion of solute into lenses of aquifer media of lesser hydraulic conductivity than the surrounding material also will affect the dispersion of the solute so that it does not follow a pattern similar to Ficke's law of diffusion (Anderson, 1979). Using the similarity to Ficke's law, other investigators have estimated dispersion coefficients that range from several inches to more than $330 \mathrm{ft}$, as indicated by Anderson (1979).

The dispersion coefficient is the product of the dispersivity of the aquifer and the velocity of flow. Because dispersivity is a property of the aquifer, the effects of uncertainty of the values for this property were tested. The sensitivity of simulated concentrations to the variation in dispersivity was estimated by testing the numerical dispersion of the HST3D simulation using centered-in-space and backwards-weighting finite-difference approximation methods.

The inability to simulate, in detail, the heterogeneities of the aquifer obviated any rigorous procedure for estimating the dispersion coefficient of the aquifer. Furthermore, the vertical spacing that would be necessary for a 


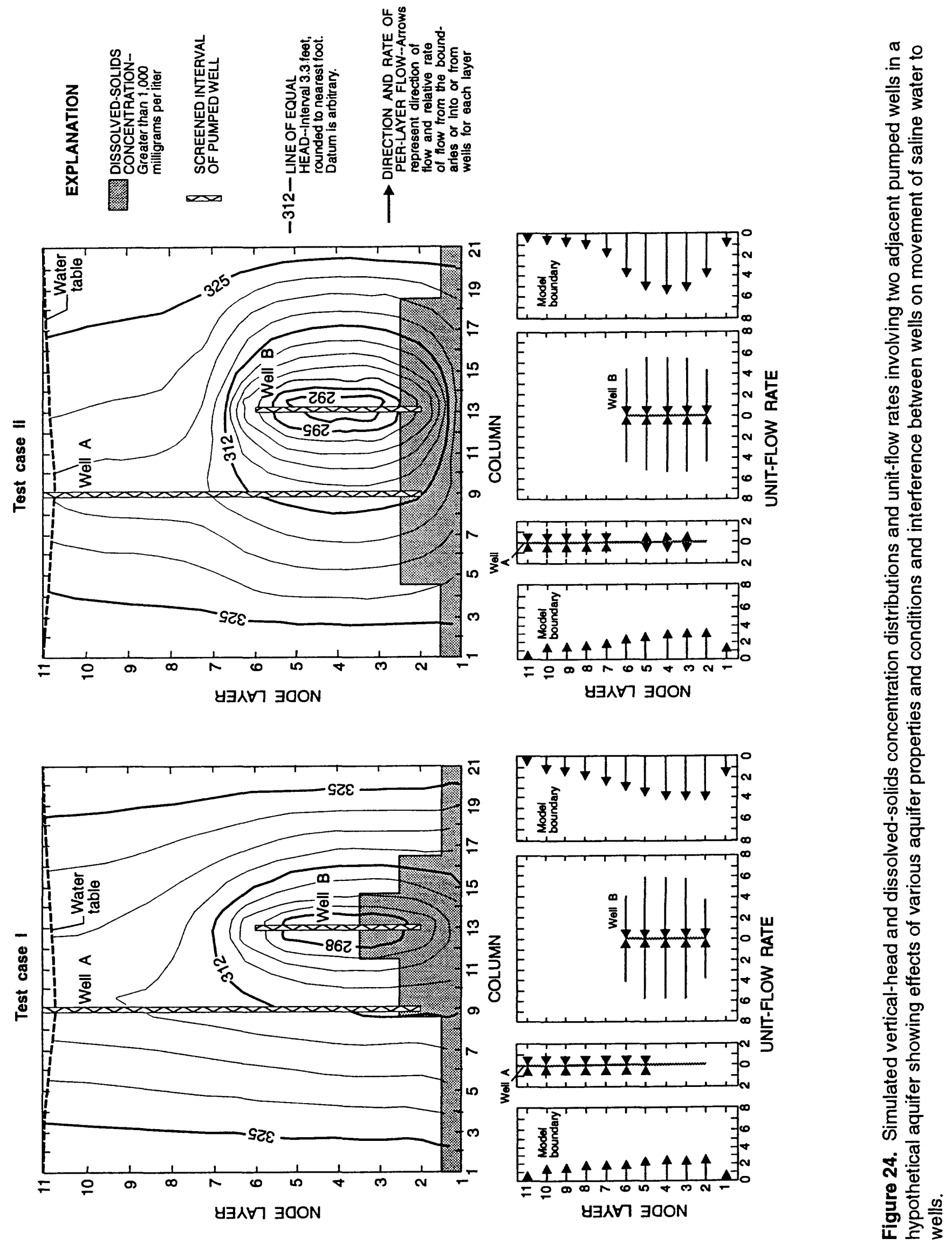



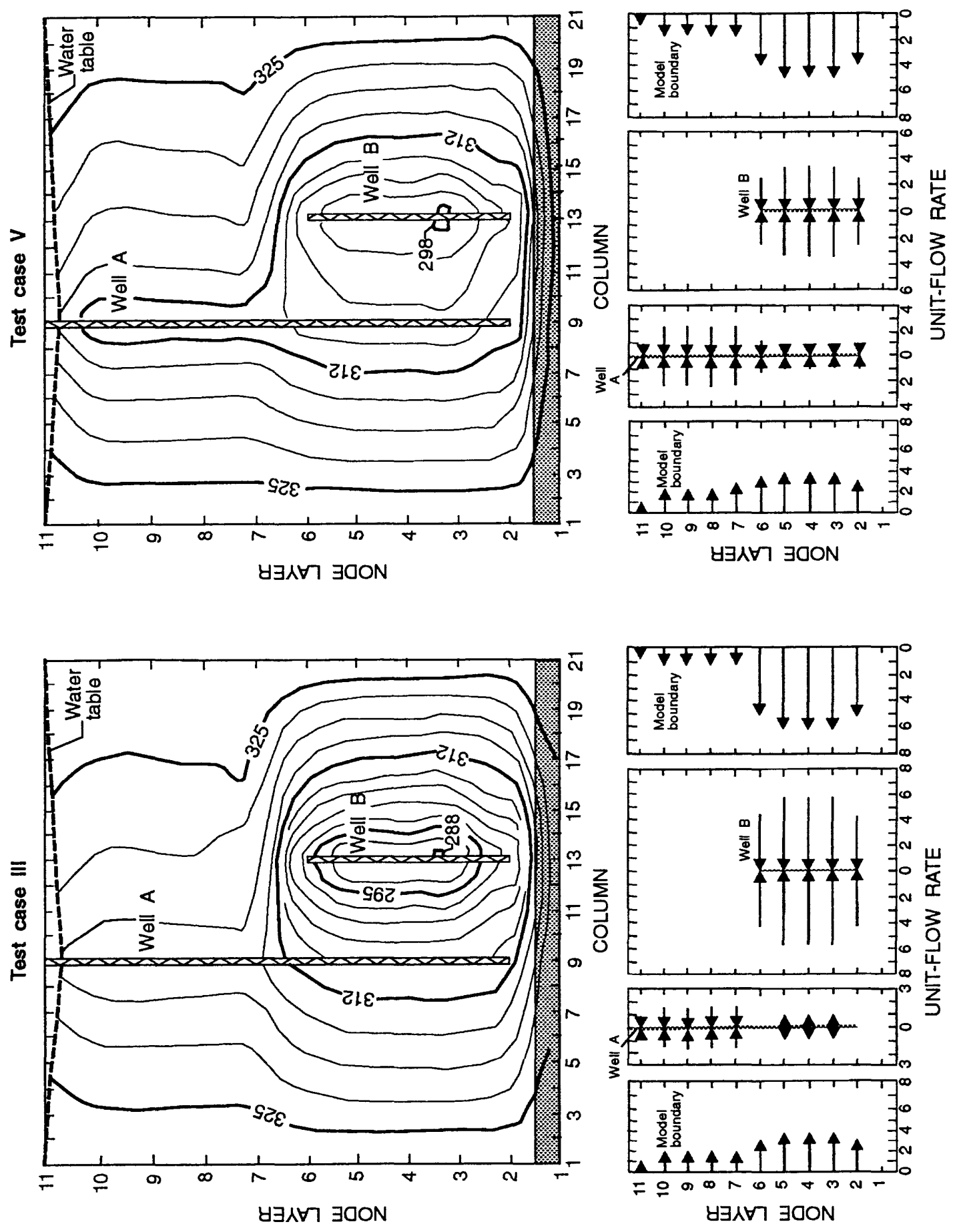

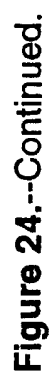


sufficiently detailed simulation of dispersion characteristics of the aquifer required more detailed data and greater computer resources than were available for this study. However, the sensitivity of simulated concentrations to the dispersion coefficient still must be tested to help identify the aquifer properties or conditions that can affect apparent movement of saline water.

A series of test simulations in one dimension for a given length of time was conducted to compare the finitedifference approximation methods with each other and with an analytical solution to the solute transport equation. The major results of these simulations are shown in figure 25 .

The curves in figure 25 show the concentration fraction plotted along a row. In figure $25 \mathrm{~A}$, the curves show the results of (1) the analytical solution from Ogata (1970, 411-I, p. 13, equation 21a) using a dispersivity of 2,640 $\mathrm{ft}$; (2) the HST3D simulation using 5,280-ft node spacing, backward-in-space and backward-in-time finite-difference approximations, and a dispersivity of zero; and (3) the HST3D simulation using 528-ft node spacing, centeredin-space and centered-in-time finite-difference approximations, and a dispersivity of 2,640 ft. The vertical line at $4.61 \mathrm{mi}$ represents the distance traveled by the front of a plug of water that does not disperse. The plug-flow curve is included for comparison. The simulated time for these results was 142 years, on the basis of a gradient that yielded a Darcy velocity of $0.47 \mathrm{ft} / \mathrm{d}$. The greatest velocity calculated in the HST3D simulation was about $0.48 \mathrm{ft} / \mathrm{d}$. The plug flow required 142 years to move $4.61 \mathrm{mi}$.

All of the curves, except the plug-flow curve, match closely. A comparison of the HST3D simulation results indicates that the amount of numerical dispersion created by using the backward-in-space approximation is equal to one-half of the node spacing. The backwards-in-space solution can be used for any size dispersivity, with respect to the node spacing, but the end result of the numerical dispersion is always equal to one-half of the node spacing. The results shown by the HST3D simulation centered-in-space solution were more correct numerically and were simulated for a node spacing 10 times finer than that of the backwards-in-space solution. The results of a test that used a node spacing of $5,280 \mathrm{ft}$, a dispersivity of $2,640 \mathrm{ft}$, and centered-in-space and centered-in-time equations were not plotted in figure 25A. The results of this test coincide with the backwards-in-space curve. The centered-in-space approximation cannot be used to simulate a much smaller dispersivity. Mathematical stability becomes a problem when the dispersivity is substantially less than one-half the node spacing with the centered-in-space approximation (Lantz, 1970; Sykes and others, 1982).

Other tests were made using the HST3D simulation to determine the possibility of using the centered-in-space and centered-in-time finite-difference approximation methods and thus used a dispersion coefficient much smaller than 2,640 ft. The analytical solution and plug-flow results are shown again in figure 25B, as are approximations by centered-in-space and centered-in-time methods. If the centered-in-space approximation could be used, this would be an improvement in simulating abrupt concentration fronts in the HST3D simulation. The results of this test also showed about 1-percent spatial oscillations in concentrations. To decrease the overall dispersivity in the HST3D simulation by a factor of 10 , the node spacing would need to be reduced to $528 \mathrm{ft}$ as for the centered-in-space solution in figure 25B. An HST3D simulation of the Hueco bolson aquifer, using 528-ft spacing, would require computing facilities beyond those available for this study.

The HST3D simulation was tested with backwards-in-space, finite-difference approximation technique, using only numerical dispersion, and with the centered-in-space finite-difference approximation, using a dispersivity of $1,320 \mathrm{ft}$. The results of these two simulations show no substantial difference. The similarity of the two results probably is caused by the large-vertical node spacing and the limited amount of saline-water movement in the historical period simulated.

Application of numerical dispersion to the simulation indicated that the amount of numerical dispersivity was about 2,640 $\mathrm{ft}$ in the area of the closest nodes. By the same reasoning, the vertical-numerical dispersivity would be about $150 \mathrm{ft}$ over all of the simulated area. The large vertical-node spacing introduced more apparent dispersion than can be accounted for by numerically-derived dispersion caused by using finite-difference approximation techniques.

The apparent dispersion in each simulation was affected by the large node spacing of the study area because two or more wells were combined into one simulated well at many nodes. The pattern of withdrawals in the 


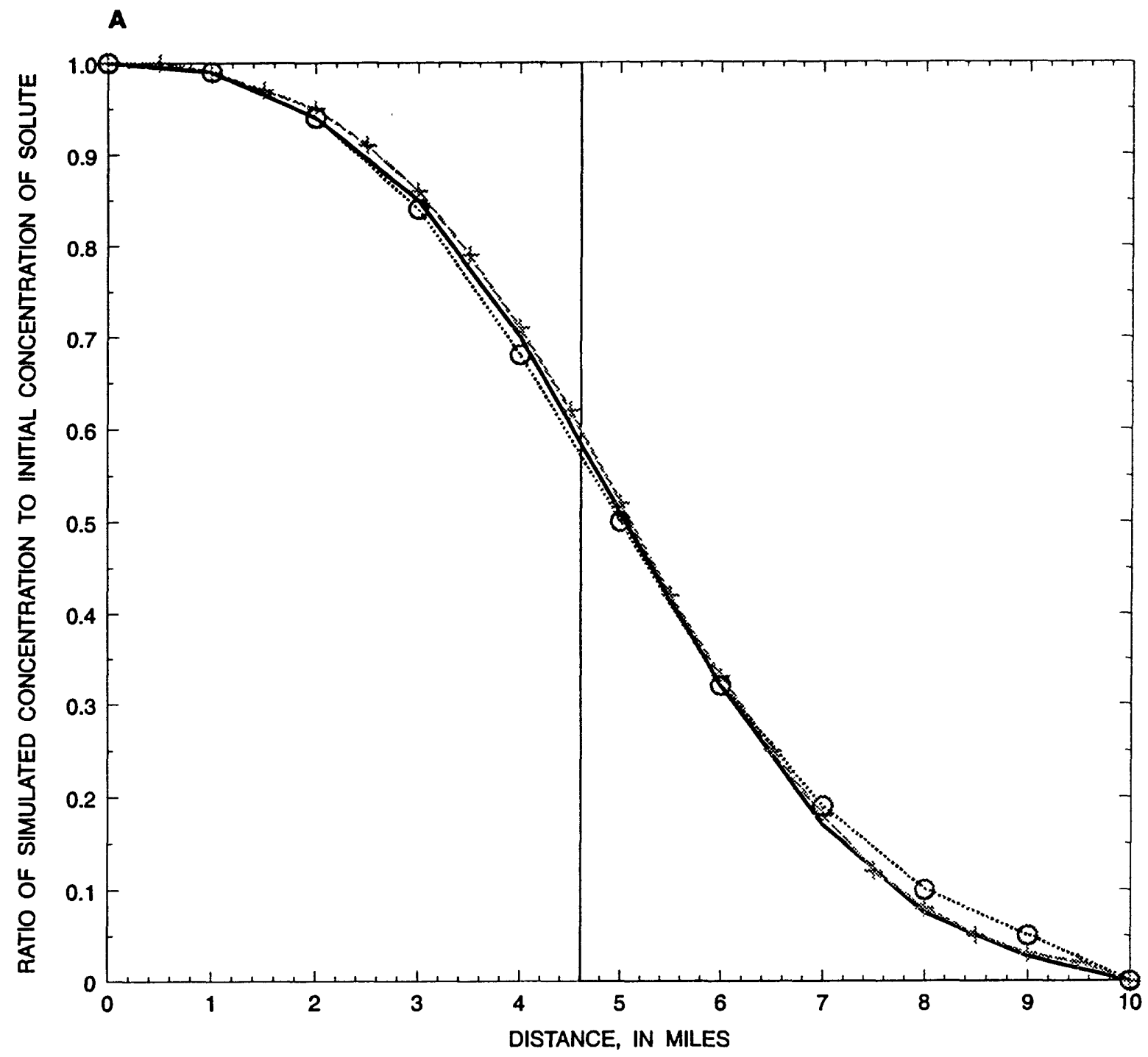

EXPLANATION

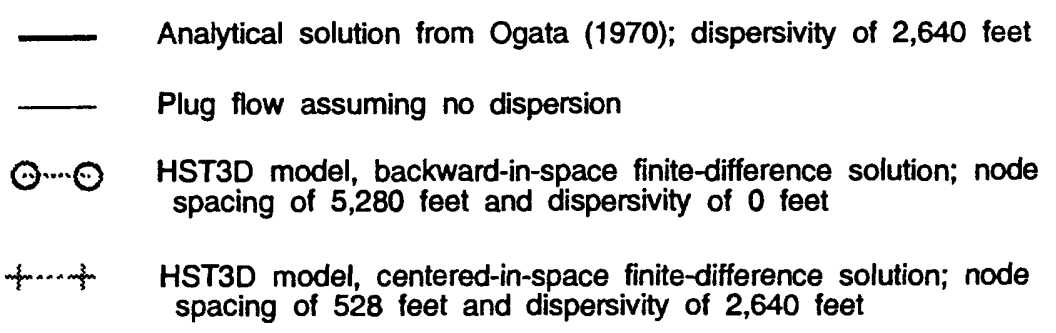

Figure 25. Solute dispersion simulated by analytical solution, plug flow with no dispersion, and (A) one heatand solute-transport three-dimensional (HST3D) backward-in-space finite-difference solution, and one HST3D centered-in-space finite-difference solution and (B) two HST3D centered-in-space finite-difference solutions with different nodal spacings and dispersivities. 


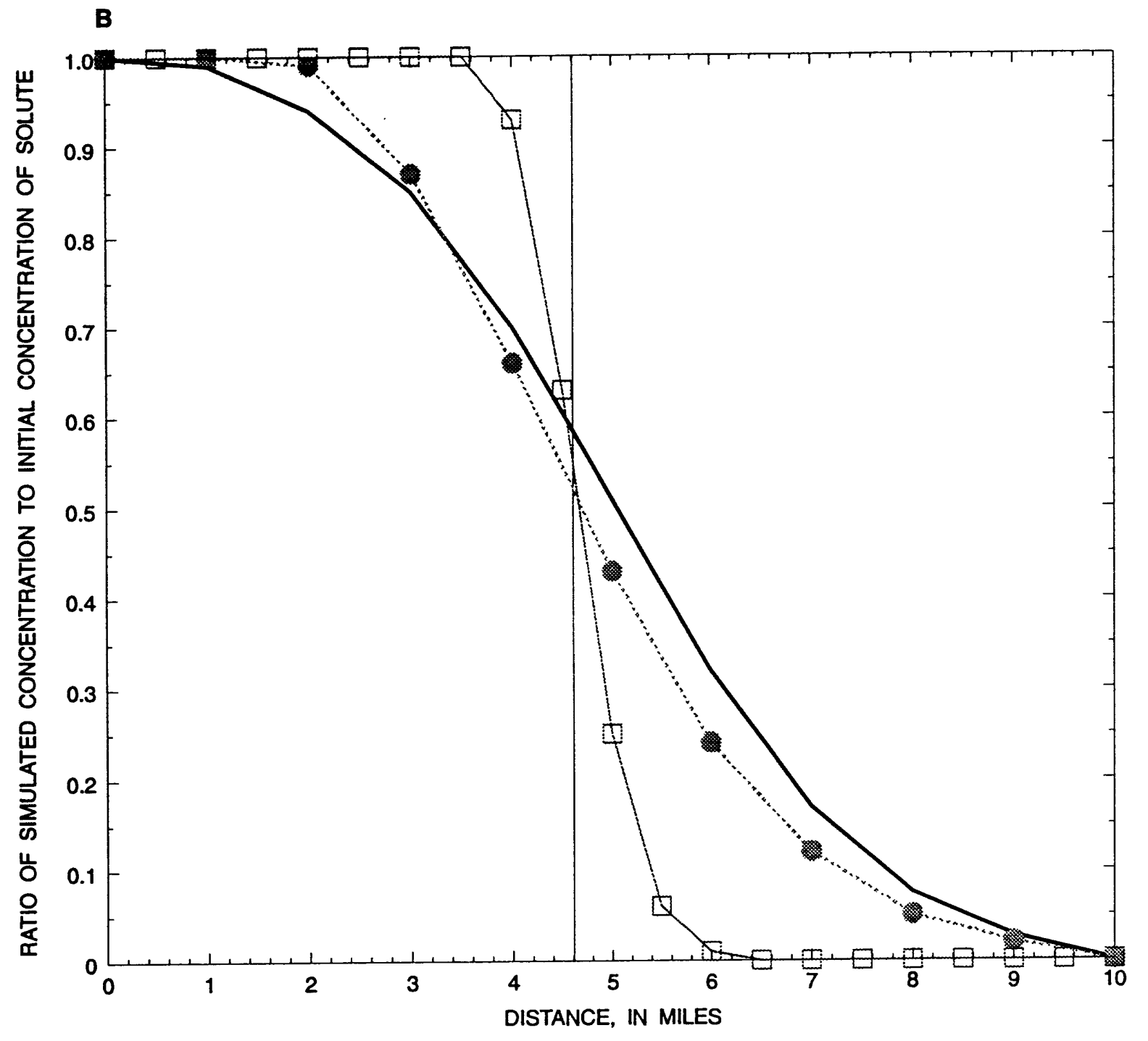

\section{EXPLANATION}

Analytical solution from Ogata (1970); dispersivity of 2,640 feet

_ Plug flow assuming no dispersion

HST3D model, centered-in-space finite-difference solution; node spacing of 5,280 feet and dispersivity of 1,320 feet HST3D model, centered-in-space finite-difference solution; node
spacing of 528 feet and dispersivity of 132 feet 
simulation is different than in the real aquifer and introduced, in some instances, more apparent dispersion where the location of the node did not coincide exactly with the map location of a well or wells, and in other instances, less apparent dispersion where several wells were combined into one simulation well. Furthermore, a complex schedule of turning well pumps on and off through a period of time less than that of a simulation period would not be evident in the simulated results. The actual schedule of well pumping would tend to increase the dispersion in the aquifer by drawing water of increased salinity toward one well and then toward another. The peak withdrawal rate during summer months for the El Paso Water Utilities-Public Service Board wells is nearly one-half the annual average water use (D.E. White, U.S. Geological Survey, written commun., 1987).

Finally, the vertical profile of the flow into a well screen is affected by the interference from other nearby wells and the vertical distribution of hydraulic conductivity. The combined effects of mutual interference and heterogeneity of the deposit stratification on the apparent dispersion from these complicated flowpaths were evident in the simulated results. The ability to accurately simulate the dispersion caused by the complex flowpaths around wells was beyond the scope of present (1984) techniques, and the necessary data were not available. On the basis of approximations of well locations and of the pumping schedules, the amount of numerical dispersion in the simulation was realistic, and the simulated results could be considered a reasonable qualitative representation of the aquifer at the regional scale.

\section{Simulation of Water-Level Changes and Movement of Saline Water}

\section{Simulated Effects of Historical Ground-Water Development}

The simulated water levels in each layer at the end of the historical simulation period (December 1983) are shown in figure 26. The simulated water-level changes in node-layers A and B, 1903-84, are shown in figure 27. The simulated dissolved-solids concentrations in node-layers A, B, C, and D for 1984 are shown in figure 28. Dissolved-solids concentrations in the bottom node plane (node-layer $\mathrm{E}$ ) are not shown because no change occurred in the simulations, and the concentrations were all 3,000 $\mathrm{mg} / \mathrm{L}$.

Most of the changes in salinity that have been observed in the El Paso area were in municipal-supply wells that have long well screens. The actual depth at which saline water enters the well screen and its concentration are difficult, and usually impossible, to determine. A small isolated lens of saline water entering the well bore cannot be distinguished from upconing of saline water from beneath the well or from movement of a large mass of saline water at the water table. In these cases, the changes in salinity from wells can be used only qualitatively. Also, part of the simulated change in concentrations is a result of numerical dispersion and, thus, might not indicate accurately the saline-water movement. Simulated changes in dissolved-solids concentrations in node-layers A, B, and C for 1958-84 are shown in figure 29. Substantial changes did not occur in node-layers D and E.

The changes in salinity in the simulations were greater in the top layer than in lower layers of the simulated aquifer because most withdrawals were from or near the water table. The well-test simulations indicated that this was generally true regardless of how deep the well screen extended below the water table. Either the large flow rate from the top layer prevented significant flow from the lower layers, or in the case of two wells interfering, the drawdown in the deeper layers was mitigated by interlayer flow from the water table through the well bore. Consequently, the result was a much smaller upward gradient from the layer underlying the freshwater zone and a correspondingly smaller upward movement of saline water. The resultant horizontal gradient was relatively small in all node layers, except the top layer.

The simulation results indicated that the greatest potential for contamination of freshwater zones was from horizontal movement of saline water at or near the water table rather than from vertical movement. This was indicated by the water levels in node-layer A and in node-layer B of the regional simulation shown in figure 26 . The horizontal gradient in node-layer A was flattened to a certain extent by the recharge in the river alluvium but was greater than that in node-layer B in the area south of the Rio Grande. The upward gradient between node-layers B and $\mathrm{C}$ was almost nonexistent. 


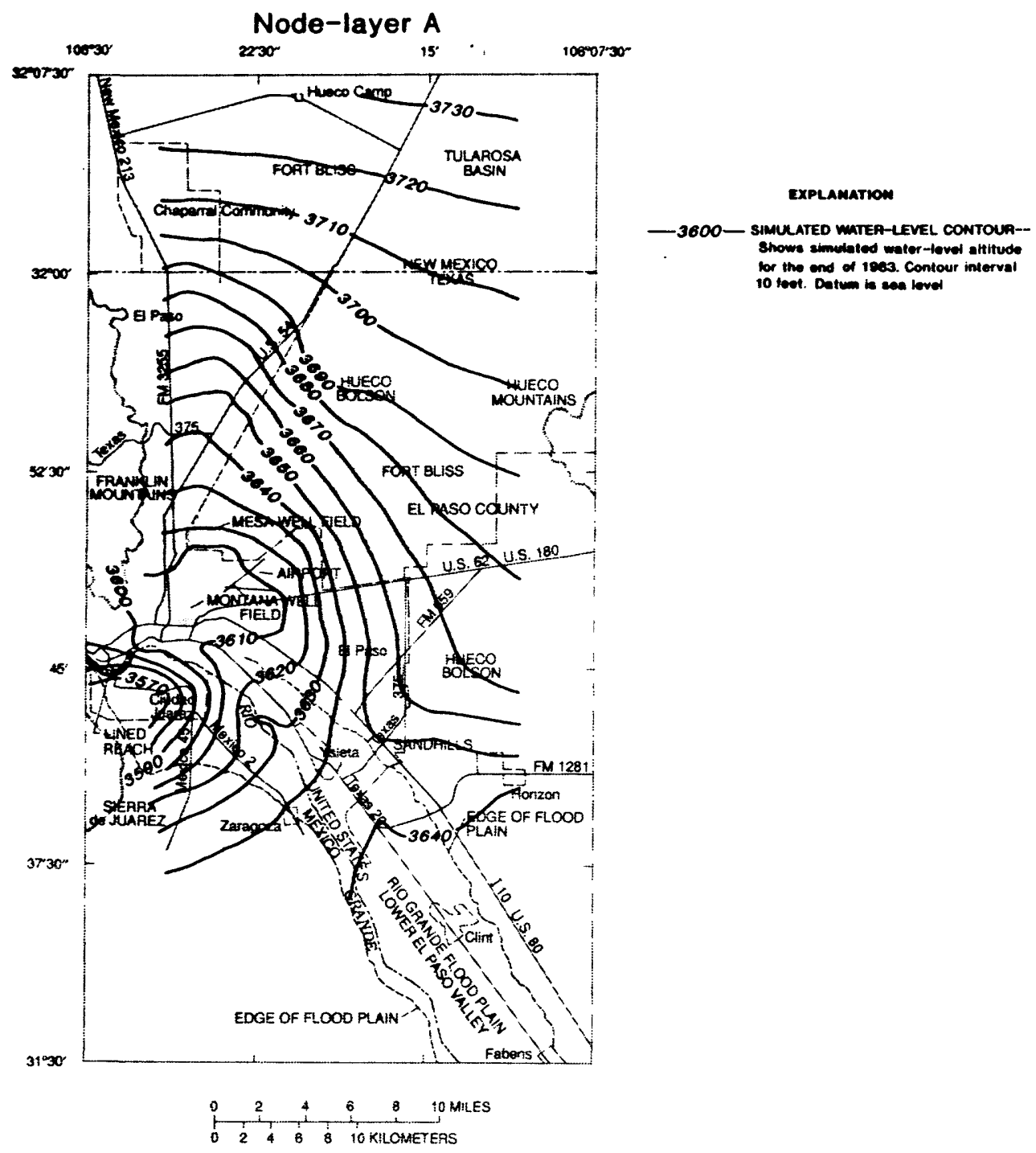

Figure 26. Simulated December 1983 water levels in node-layers A, B, C, D, and E of the Hueco bolson aquifer. 

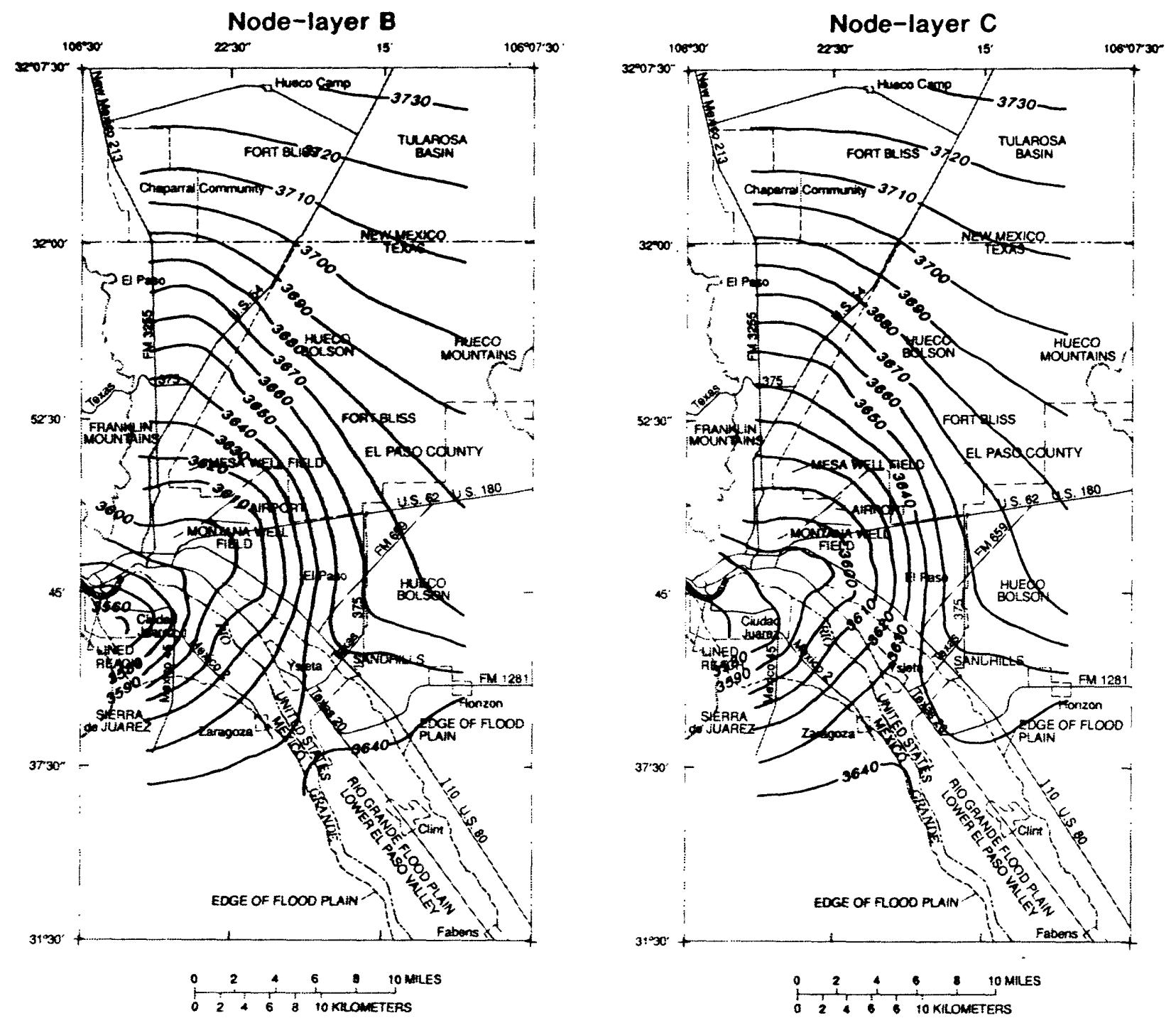

Figure 26.--Continued. 

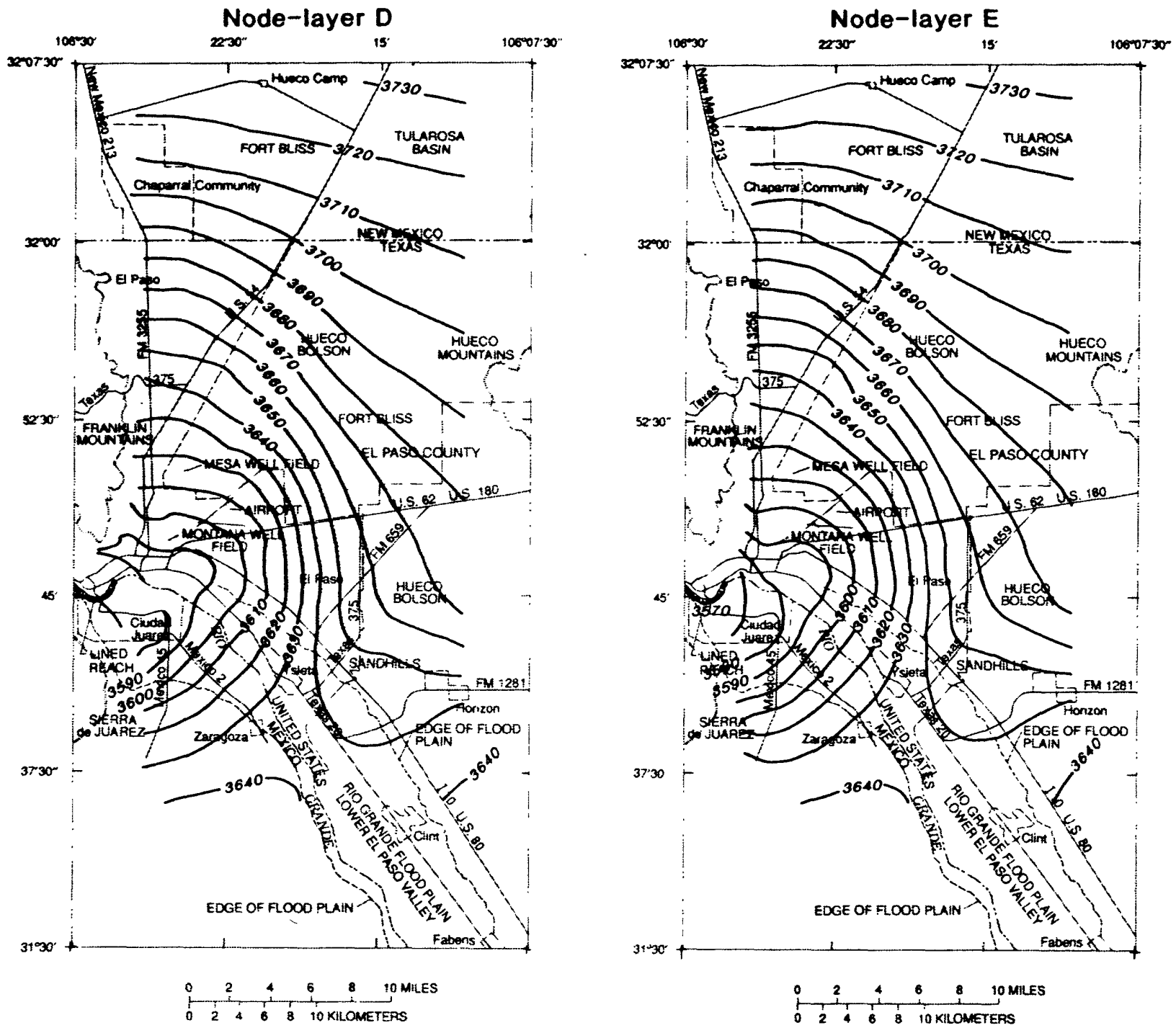

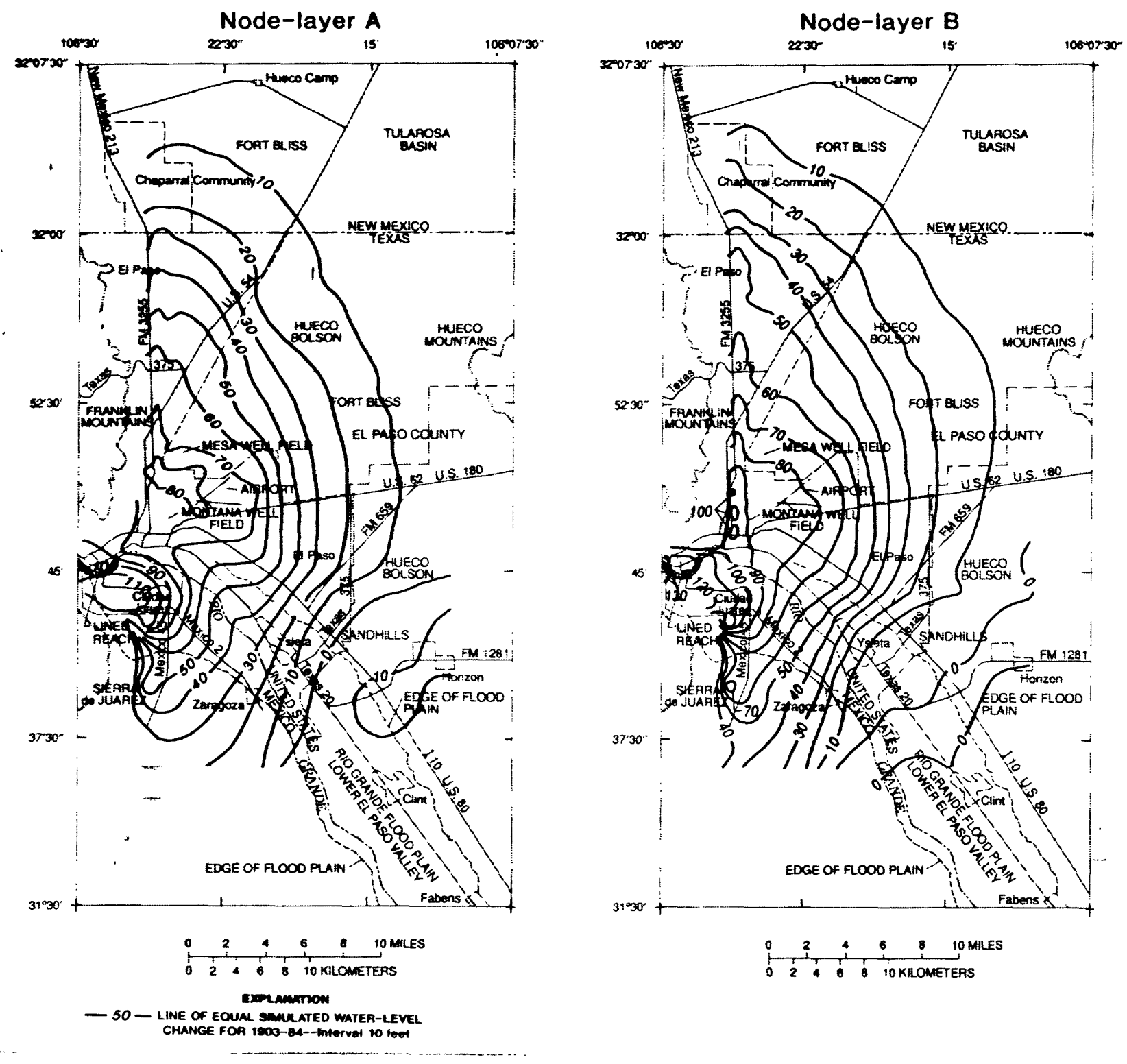

Figure 27. Simulated water-level changes in node-layers A and B of the Hueco bolson aquifer, 1903-84. 
The simulated water levels shown in figure 26 included the free surface that represented the top of the saturated section of aquifer material. As shown in Land and Armstrong (1985), a continuous saturated zone did not underlie all parts of the river. Water levels in vertically discrete piezometers indicated that the "column" of ground water from the river, canal, and irrigation return flow moves through sections of complete saturation and partial saturation. The hydraulics of water movement under conditions of partial saturation are complex and not well understood, and the movement of solute under partial saturation is even more complex. The simulations discussed in this report are only approximations under assumed complete saturation. Also, the effects of partial saturation on well flow are not addressed. Finally, the flow field can, and probably will, be extensively altered from the conditions simulated by specific well pumping schedules--effects not included in the simulation--and by changing well-field plans caused by future changes in salinity. For instance, saline water can begin to enter a well near the saline-water source, but when that well is idle, the saline water will begin to move toward other wells that continue to withdraw water.

\section{Simulated Effects of Projected Ground-Water Development}

The simulated water-level altitudes for the year 2000 in response to two series of estimates for projected (1984-2000) ground-water withdrawals (table 2) are shown in figure 30. The results indicated that the area of greatest water-level decline would continue to be near the river under El Paso and Ciudad Juarez. The deepest water levels--about 3,455 ft above sea level for the larger estimate of projected (1984-2000) ground-water withdrawals and $3,465 \mathrm{ft}$ above sea level for the smaller estimate of projected withdrawals (table 1)--are under Ciudad Juarez just south of the Rio Grande. The simulated water-level changes for 1903-2000 in node-layers A and B for the smaller estimate of projected (1984-2000) ground-water withdrawals are shown in figure 31. The simulated water-level changes, 1903-2000, in node-layers A and B for the larger estimate of projected (1984-2000) ground-water withdrawals are shown in figure 32.

The simulated hydraulic gradient from node-layer A to node-layer B for January 2000 is shown in figure 33. The gradient is the same for both estimates of projected (1984-2000) ground-water withdrawals. The area, as well as the magnitude, of the downward gradient are projected to continue to increase. The area several miles south of the Texas-New Mexico State line and north of the Mesa well field shows the hydraulic gradient resulting from the proposed injection of water in that area. The injected water flows mainly to the water-table zone and then slowly moves downward and out from the zone of injection.

The area of greatest decline extends northeast to the El Paso airport. The difference between the two estimates does not result in large differences in simulated water levels for 1984-2000 at this scale. Locally, perhaps with a finer-grid simulation, large differences would be simulated depending on the assumed distribution and pumping schedule of wells.

The simulated dissolved-solids concentrations, for January 2000, in node-layers A, B, C, and D in response to two estimates of projected (1984-2000) ground-water withdrawals are shown in figure 34 . The effect of the proposed injection of water also can be seen in figure 34. In the northern one-half of the freshwater zone, 3 to 4 mi south of the Texas-New Mexico State line, is a closed contour of $500 \mathrm{mg} / \mathrm{L}$. The area located within the oval shaped area bounded by the contour had dissolved-solids increases of less than $100 \mathrm{mg} / \mathrm{L}$ and does not appear on the maps of simulated changes in concentration. The increase in dissolved solids in this part of the aquifer is caused by the simulated injection of effluent with a concentration of $700 \mathrm{mg} / \mathrm{L}$ dissolved solids.

Changes in dissolved-solids concentrations for 1984-2000 in node-layers A, B, and C are shown in figure 35 in response to the smaller estimate of projected withdrawals (table 1) and in figure 36 in node-layers A and B in response to the larger estimate of projected (1984-2000) ground-water withdrawals. Changes in dissolved-solids concentrations in node-layer $\mathrm{C}$ are not shown for the larger estimate in figure 36 because the results between the smaller and larger estimates of projected withdrawals differed in only one cell. Substantial changes in concentration were not evident for layers $\mathrm{D}$ and $\mathrm{E}$.

The results indicate that the saline-water movement would continue in approximately the same areas and in the same directions as were indicated for the historical simulation period. Most large changes in salinity would occur 

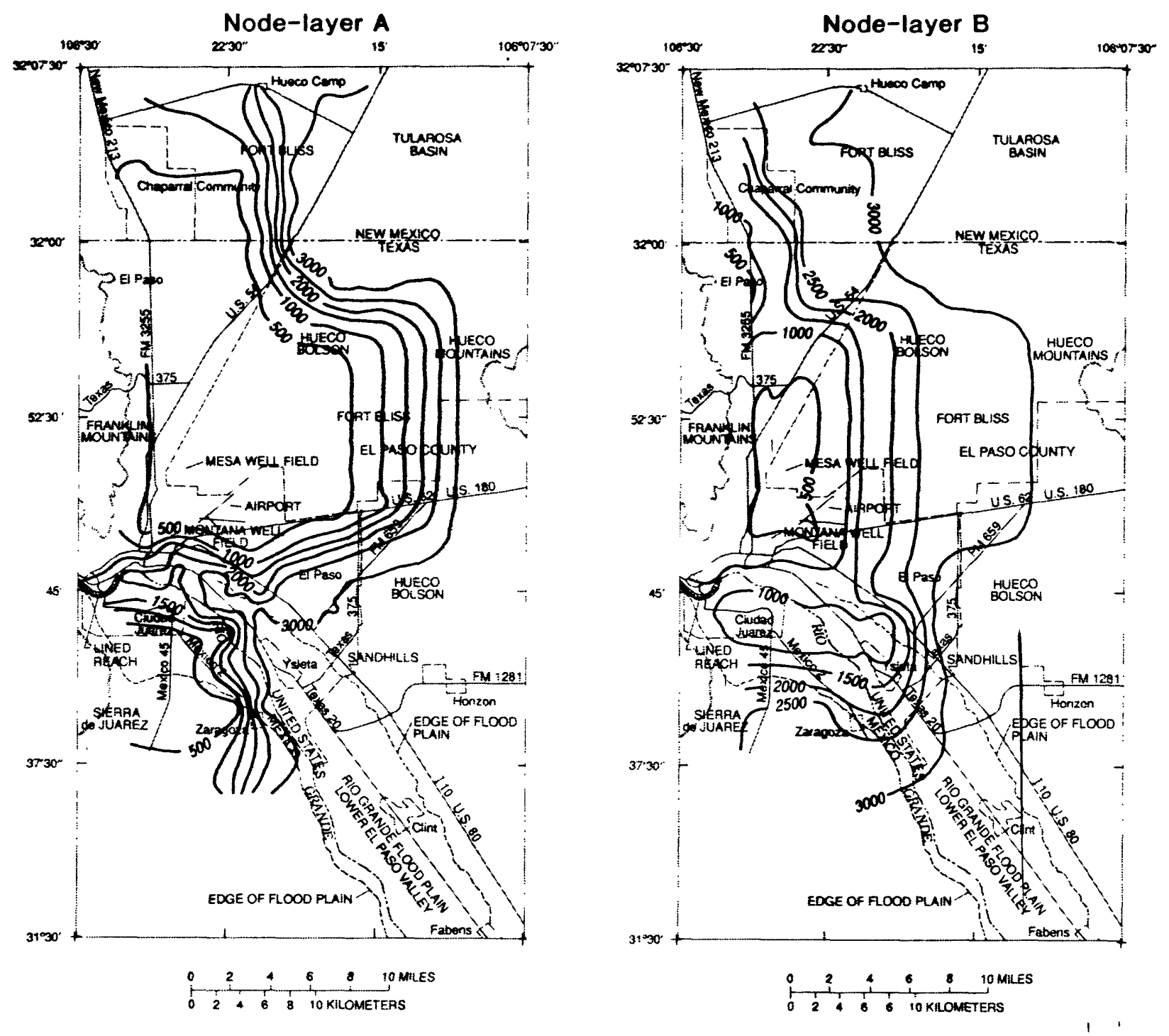

EXPLAMATION

-1000 - LINE OF EOUAL SMMULATED DISSOLVED-SOLIOS CONCENTRATHON--mterval 500 milligrams per liter

Figure 28. Simulated dissolved-solids concentrations in node-layers A, B, C, and D of the Hueco bolson aquifer, 1984. 

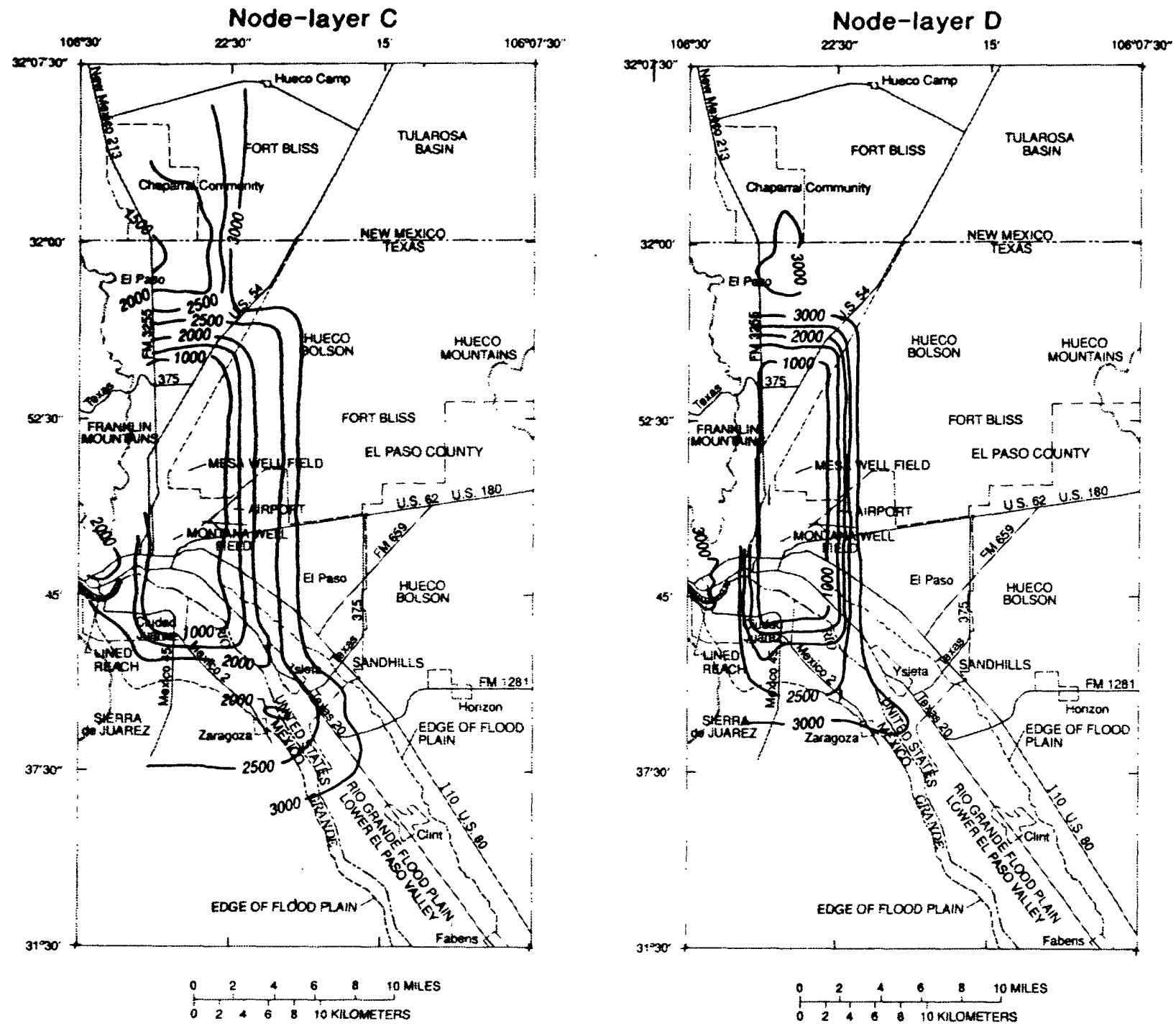


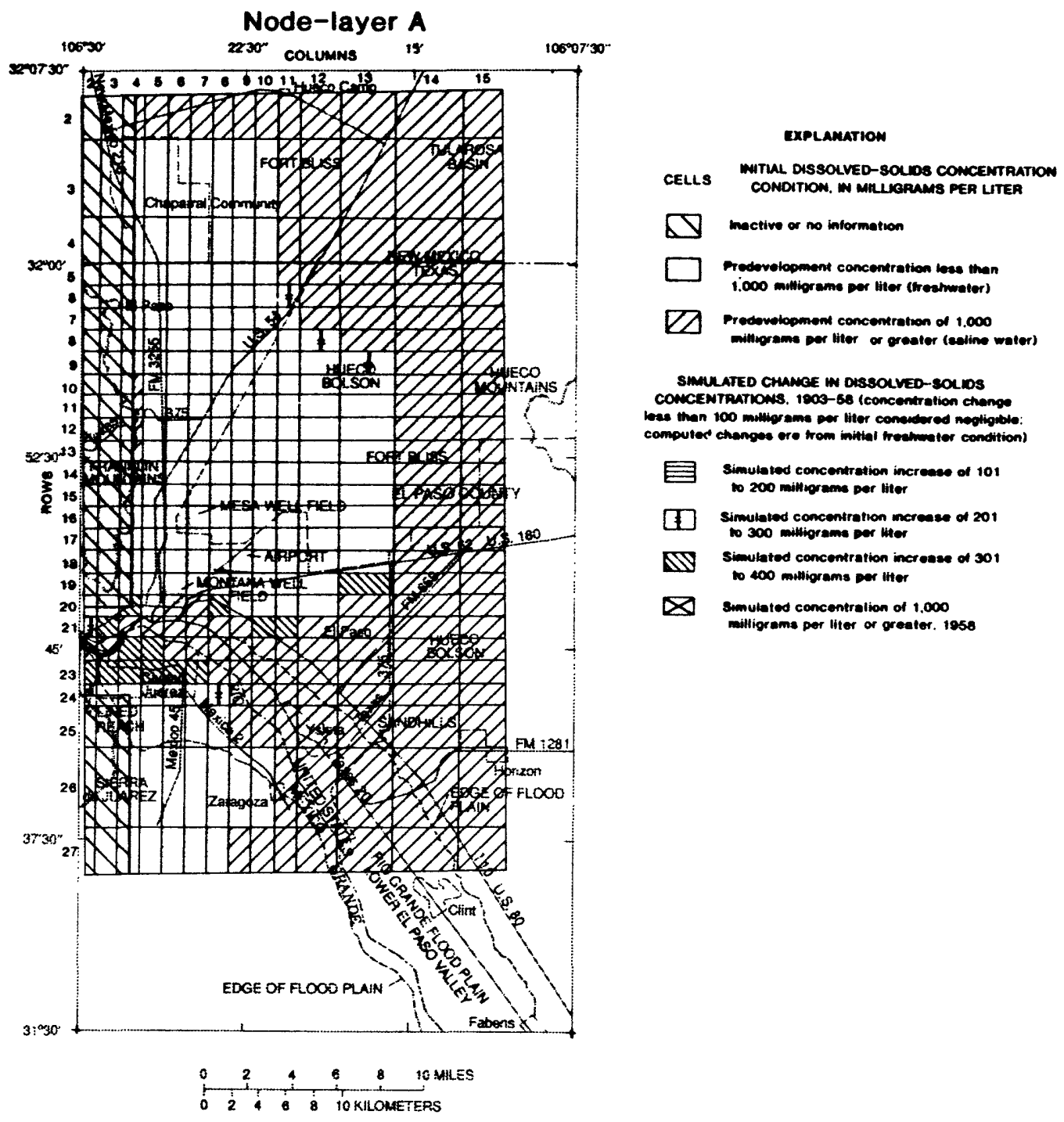

Figure 29. Simulated changes in dissolved-solids concentrations in node-layers $A, B$, and $C$ of the Hueco bolson aquifer, 1958-84. 

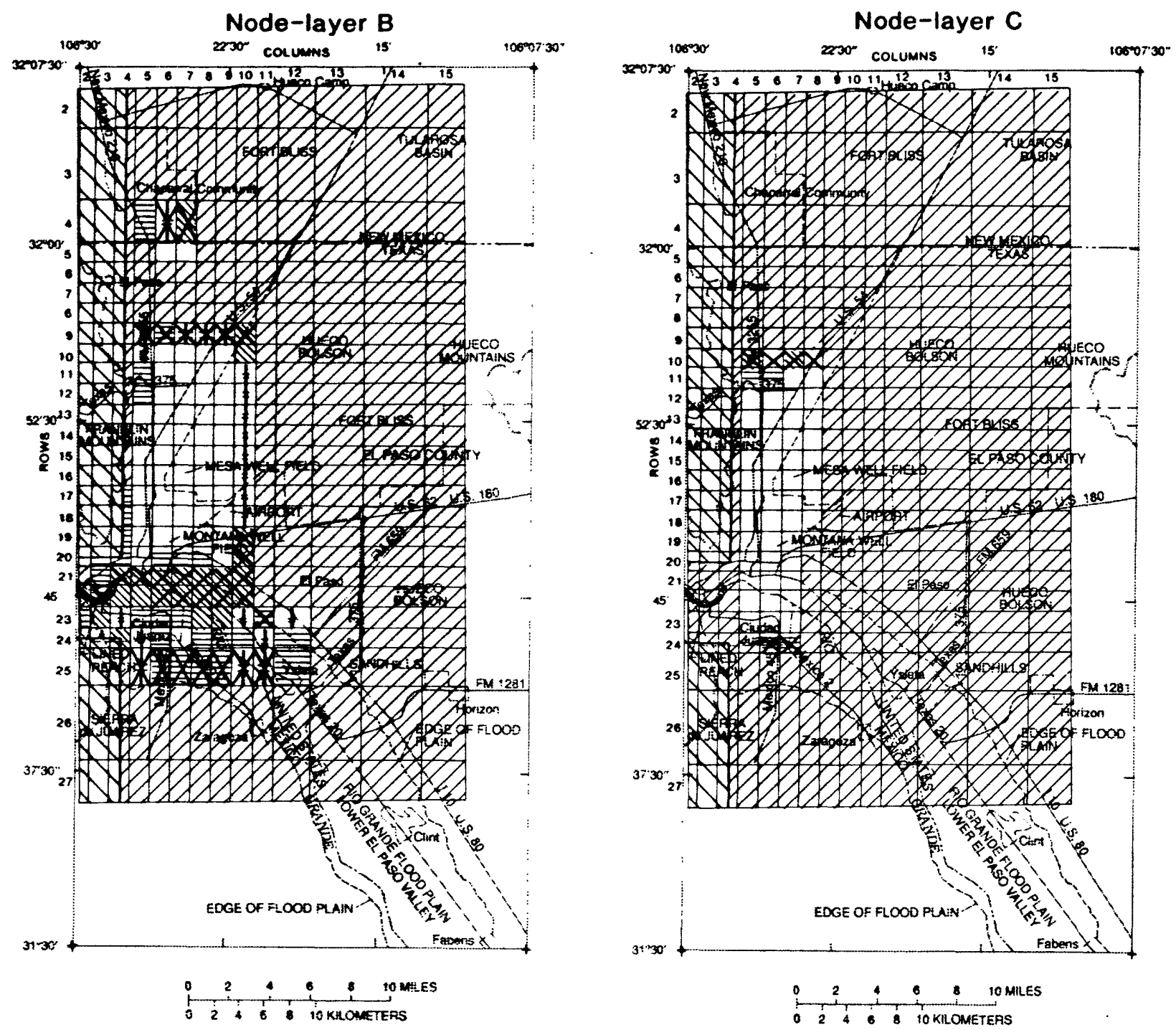


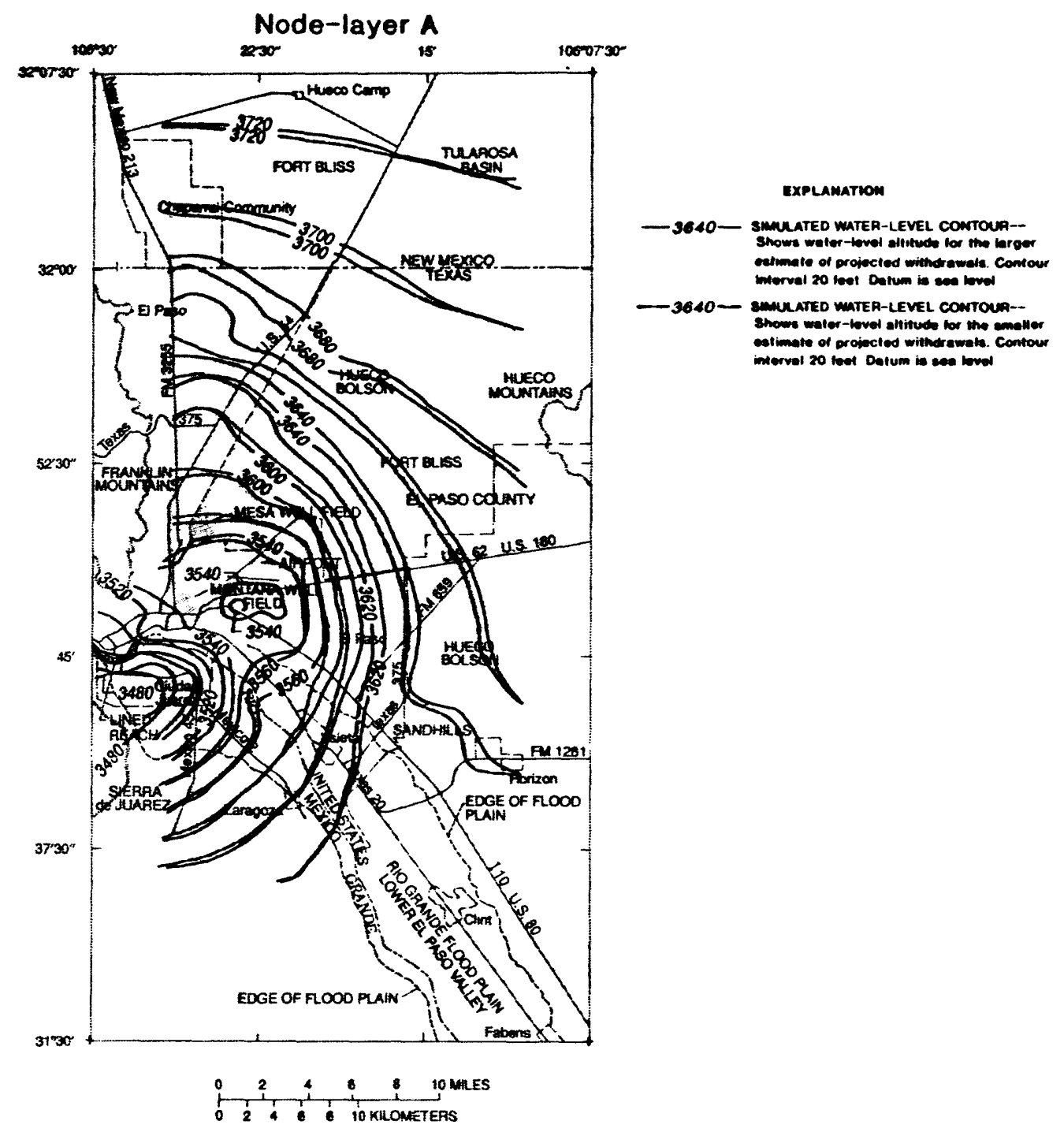

Figure 30. Simulated water-level altitudes for the year 2000 in node-layers A, B, C, D, and E of the Hueco bolson aquifer in response to two estimates of projected (1984-2000) ground-water withdrawals. 

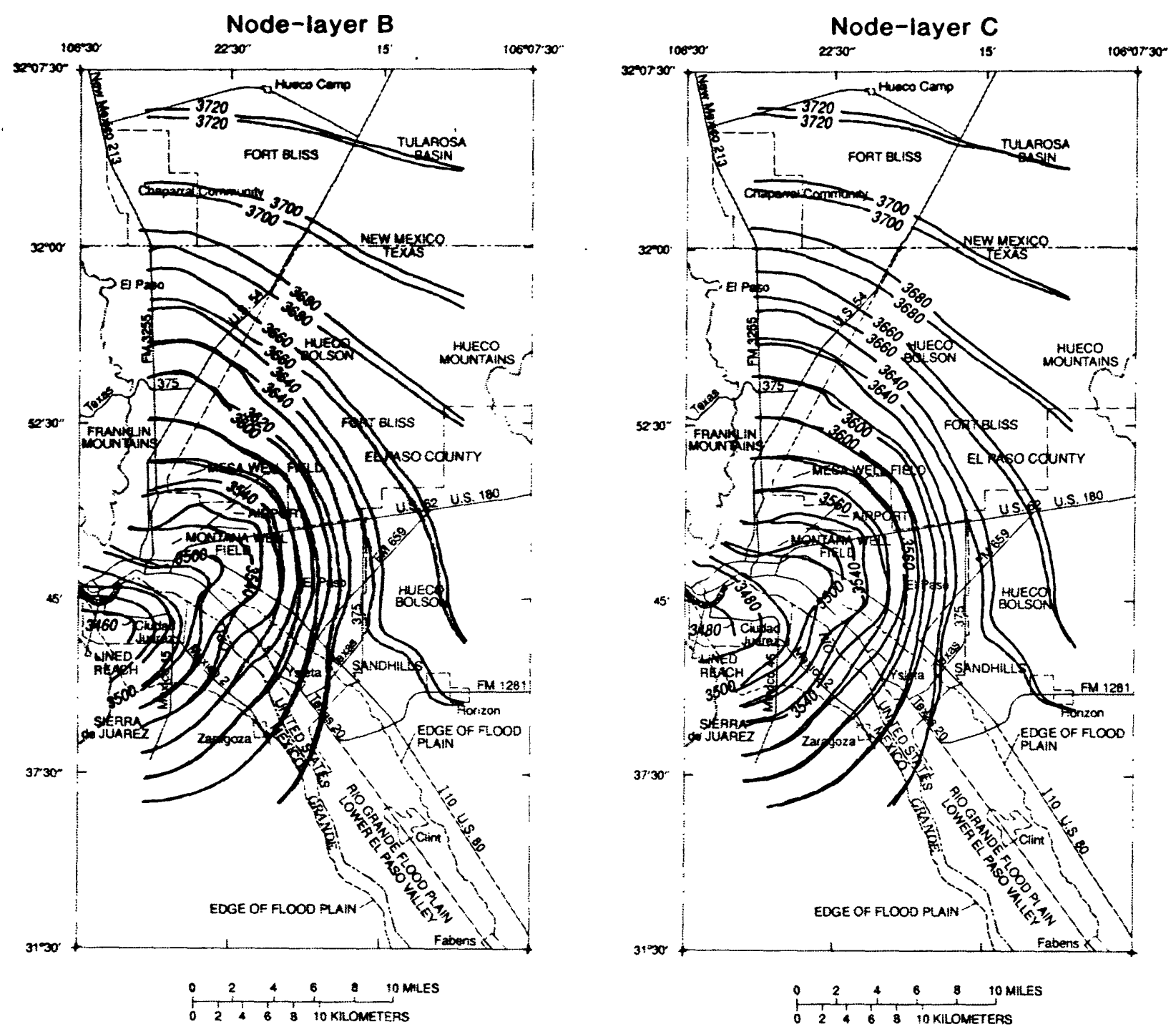

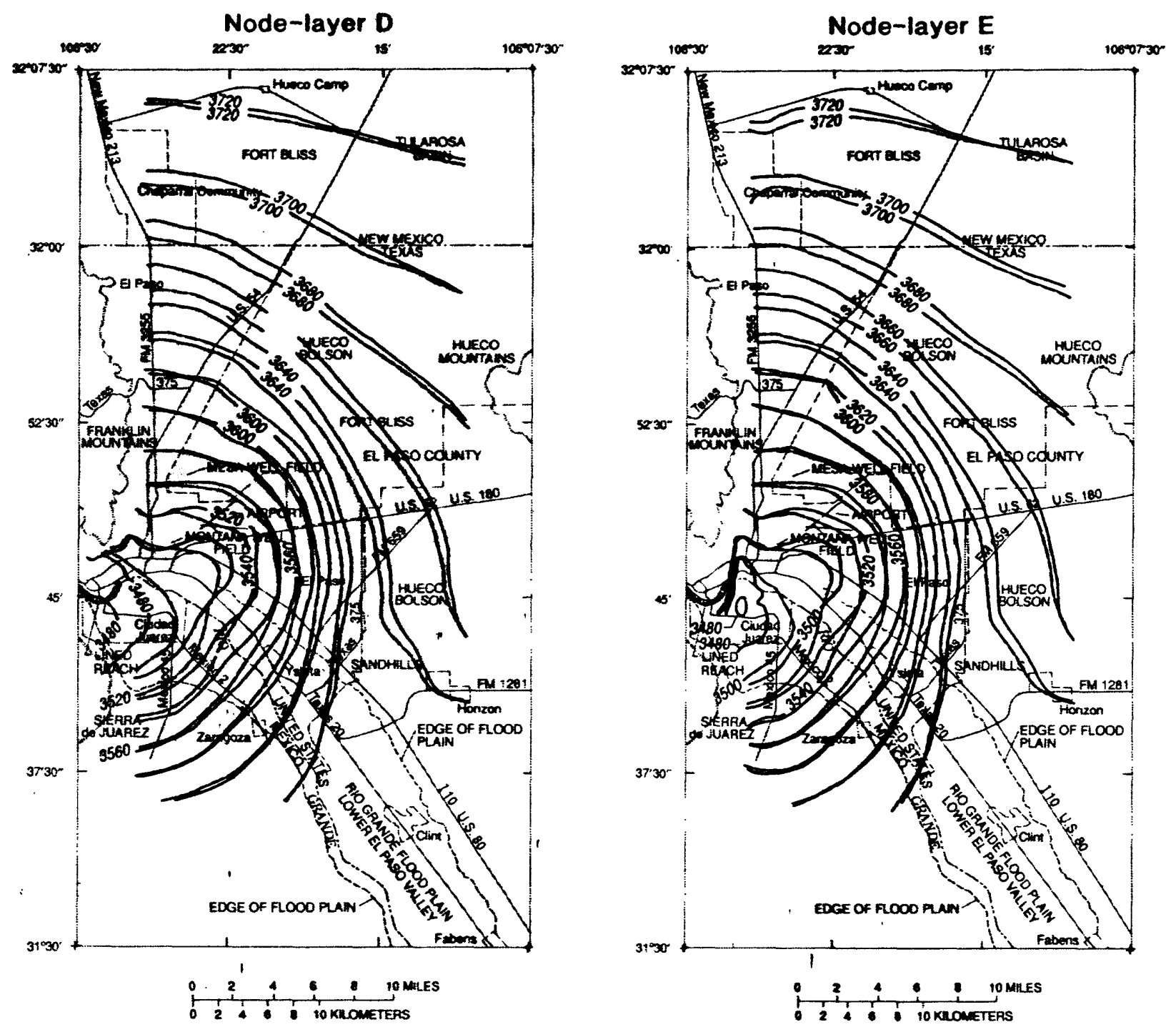

Figure 30.--Continued. 

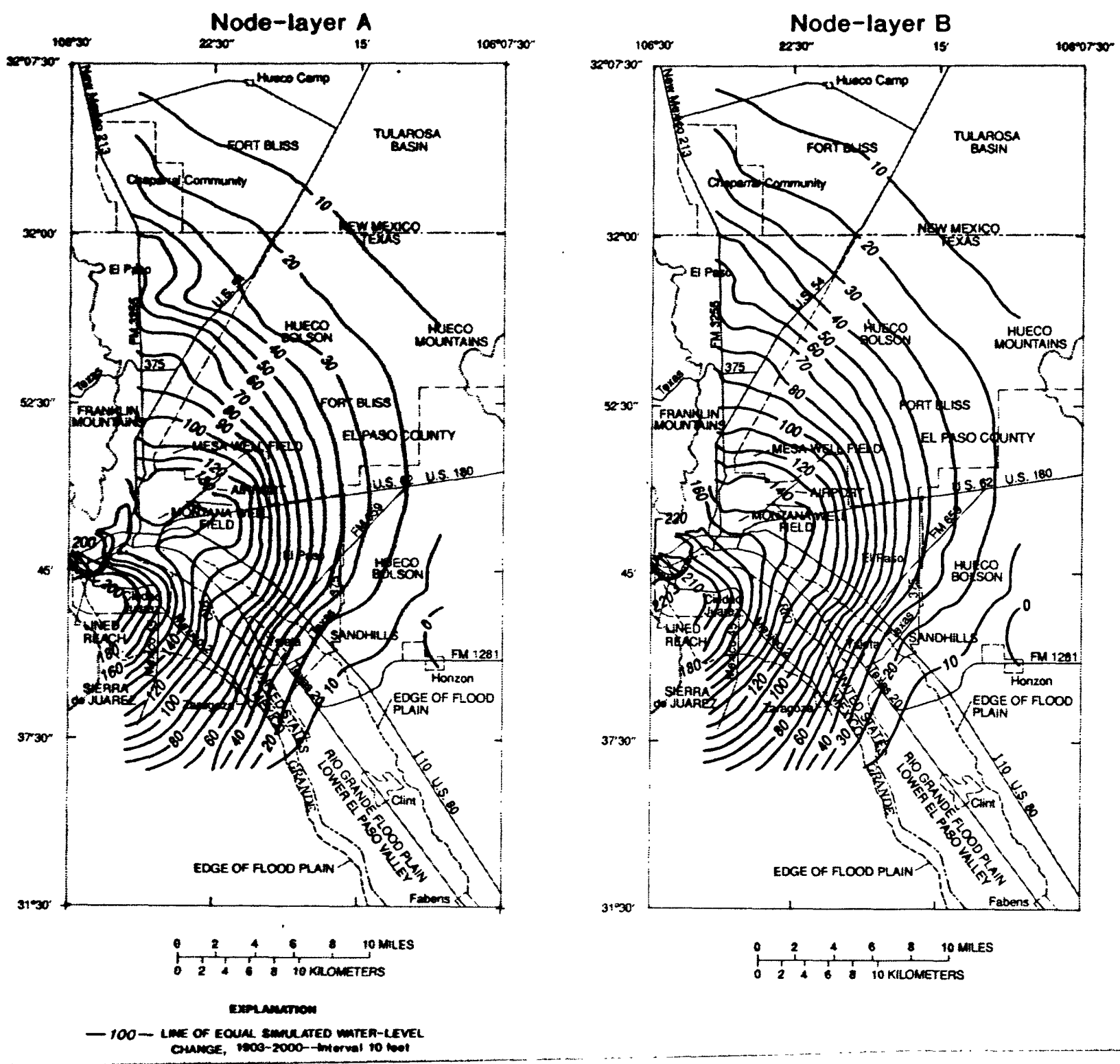

Figure 31. Simulated water-level changes, 1903-2000, in node-layers A and B of the Hueco bolson aquifer in response to the smaller estimate of projected (1984-2000) ground-water withdrawals. 

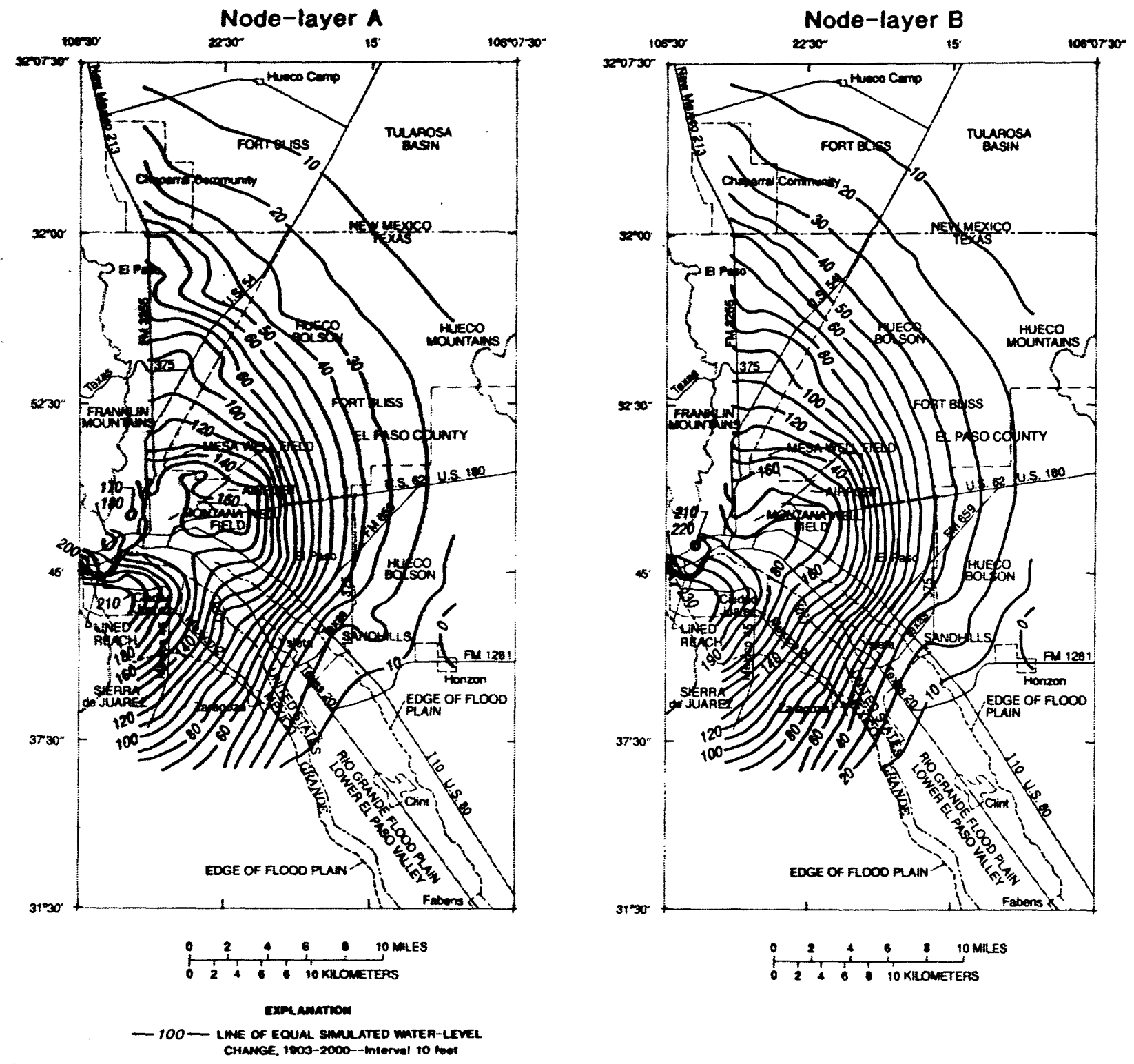

Figure 32. Simulated water-level changes, 1903-2000, in node-layers $A$ and $B$ of the Hueco bolson aquifer in response to the larger estimate of projected (1984-2000) ground-water withdrawals. 


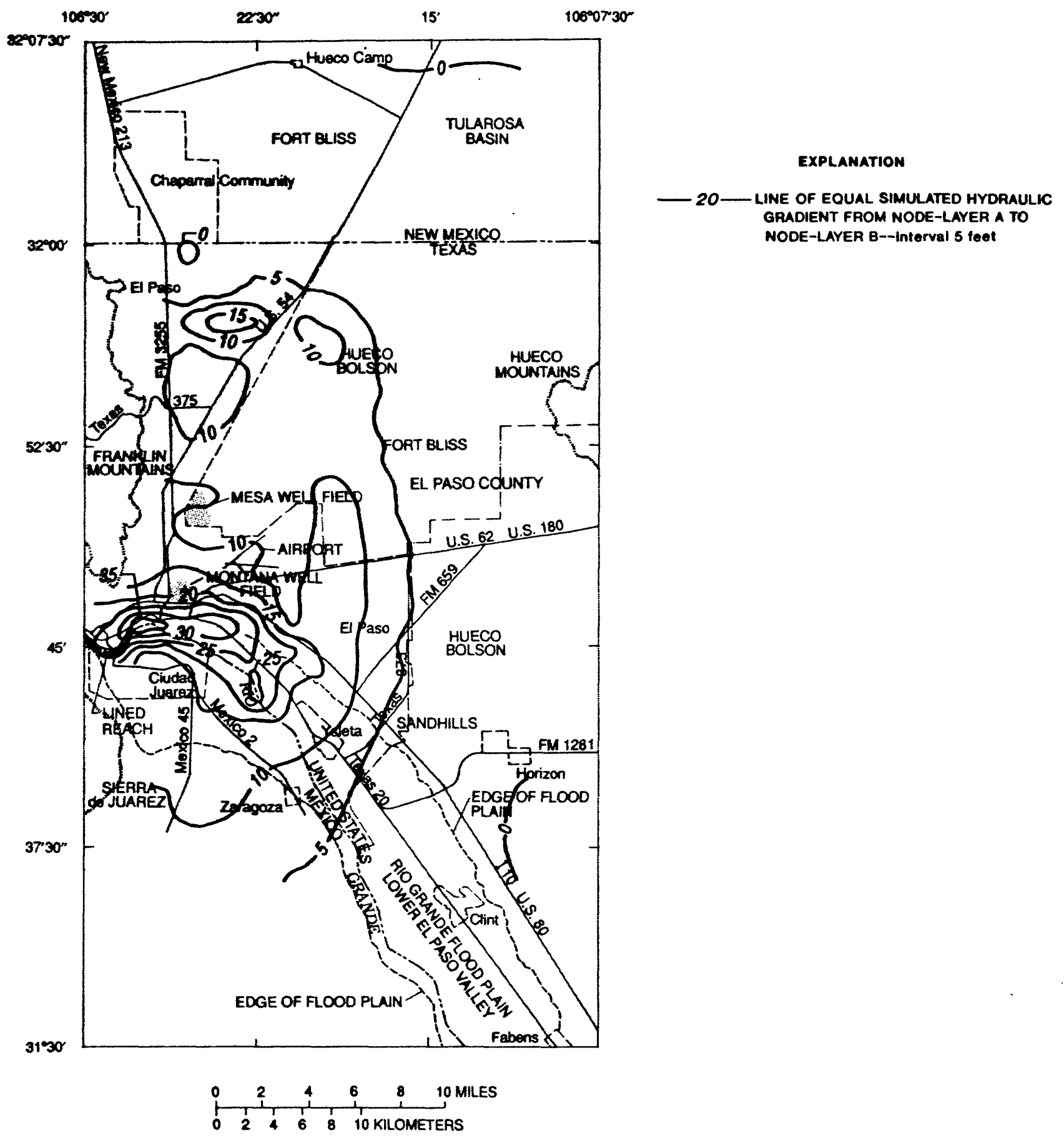

Figure 33. Simulated-hydraulic gradient, January 2000 , from node-layer $A$ to node-layer $B$ of the Hueco bolson aquifer in response to both estimates of projected (1984-2000) ground-water withdrawals. 

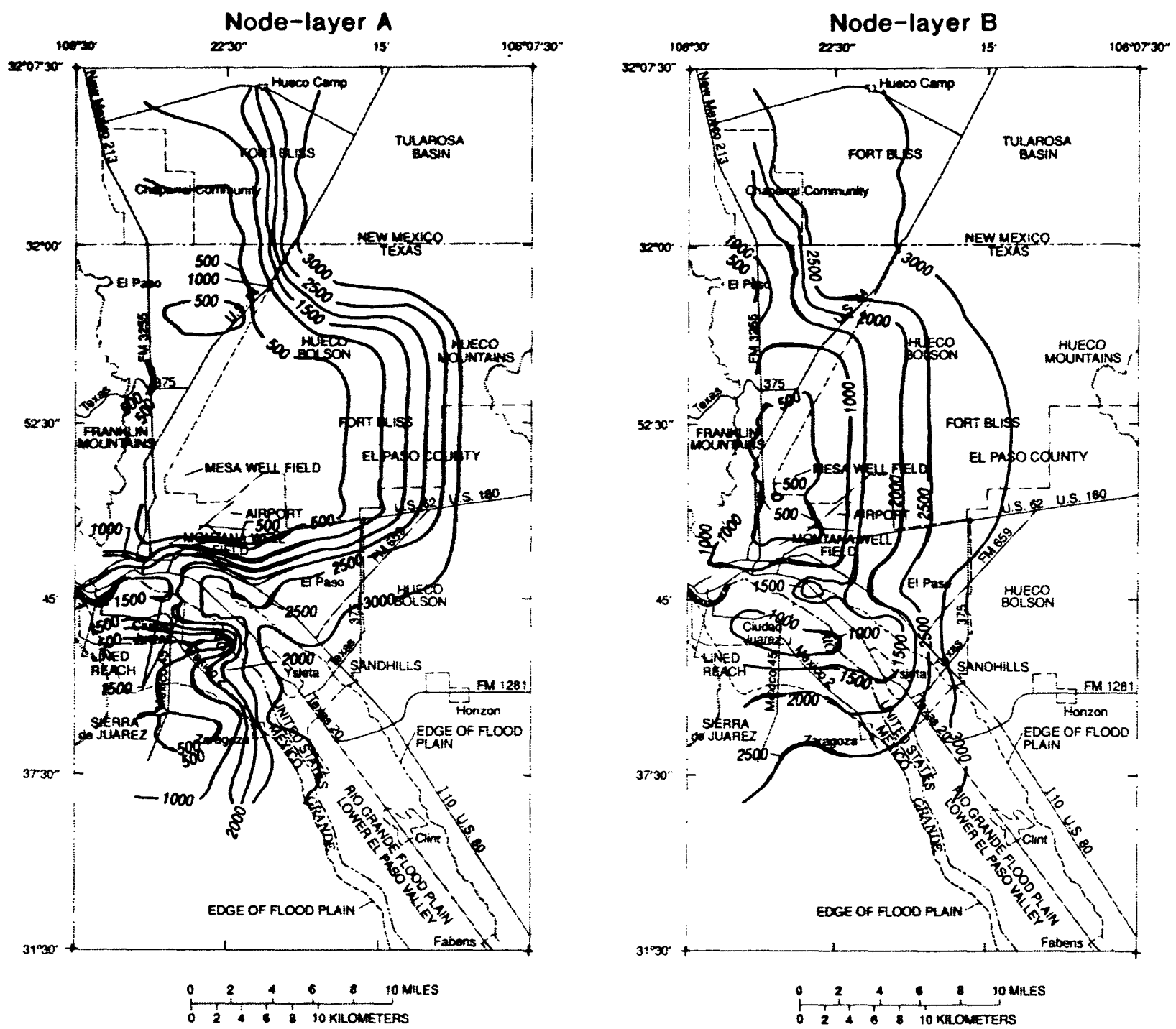

expaminom

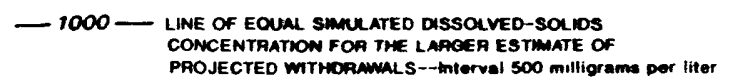

- 1000 - LAME OF EQUAL SMMUATED DISSOLVED-SOLIDS TRATION FOP THE SMALLEA ESTIMATE OF PROJECTED WITHORAWALS--mierval 500 milligrams per liter

Figure 34. Simulated dissolved-solids concentrations, January 2000 , in node-layers A, B, C, and D of the Hueco bolson aquifer in response to two estimates of projected (1984-2000) ground-water withdrawals. 

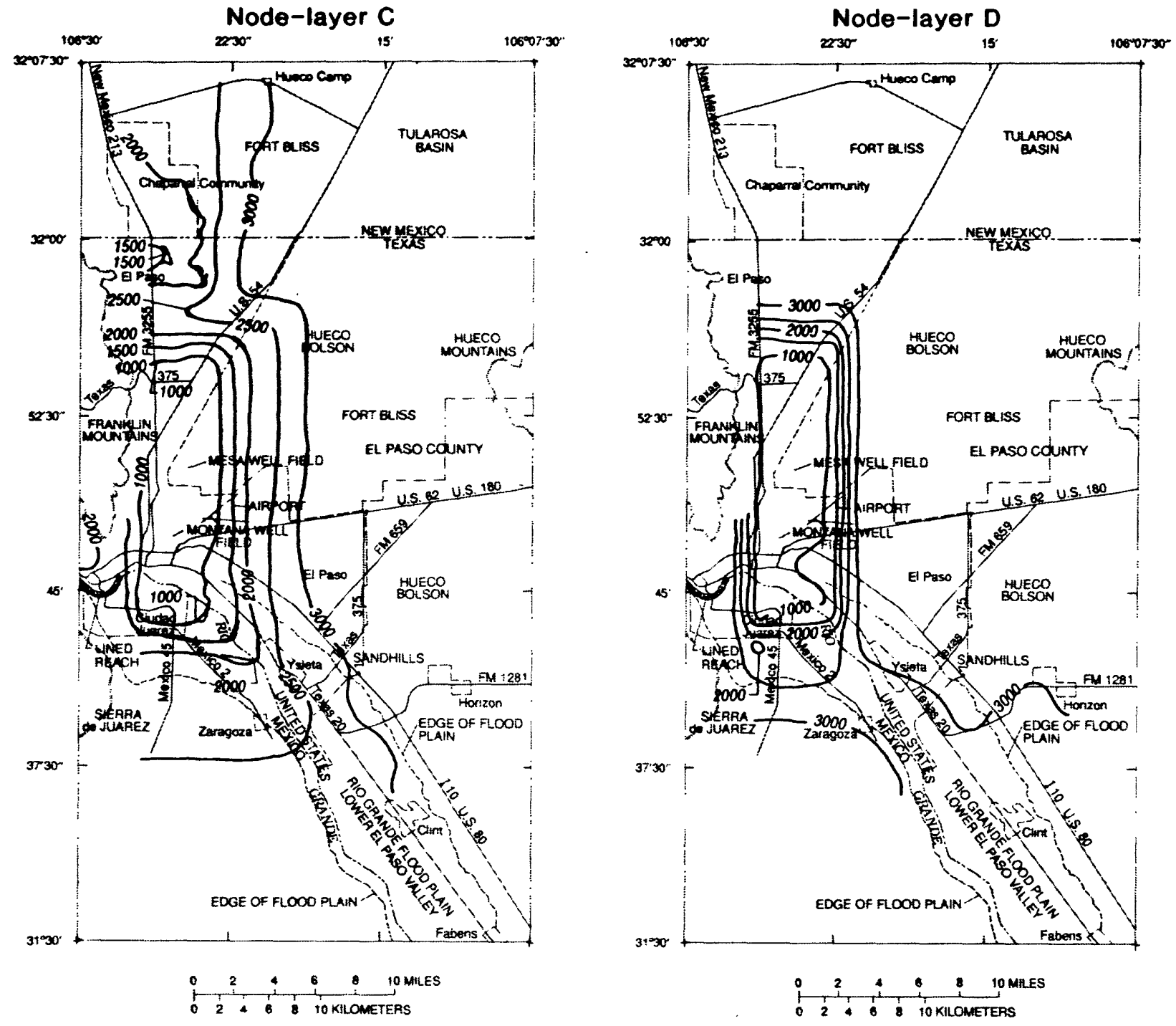


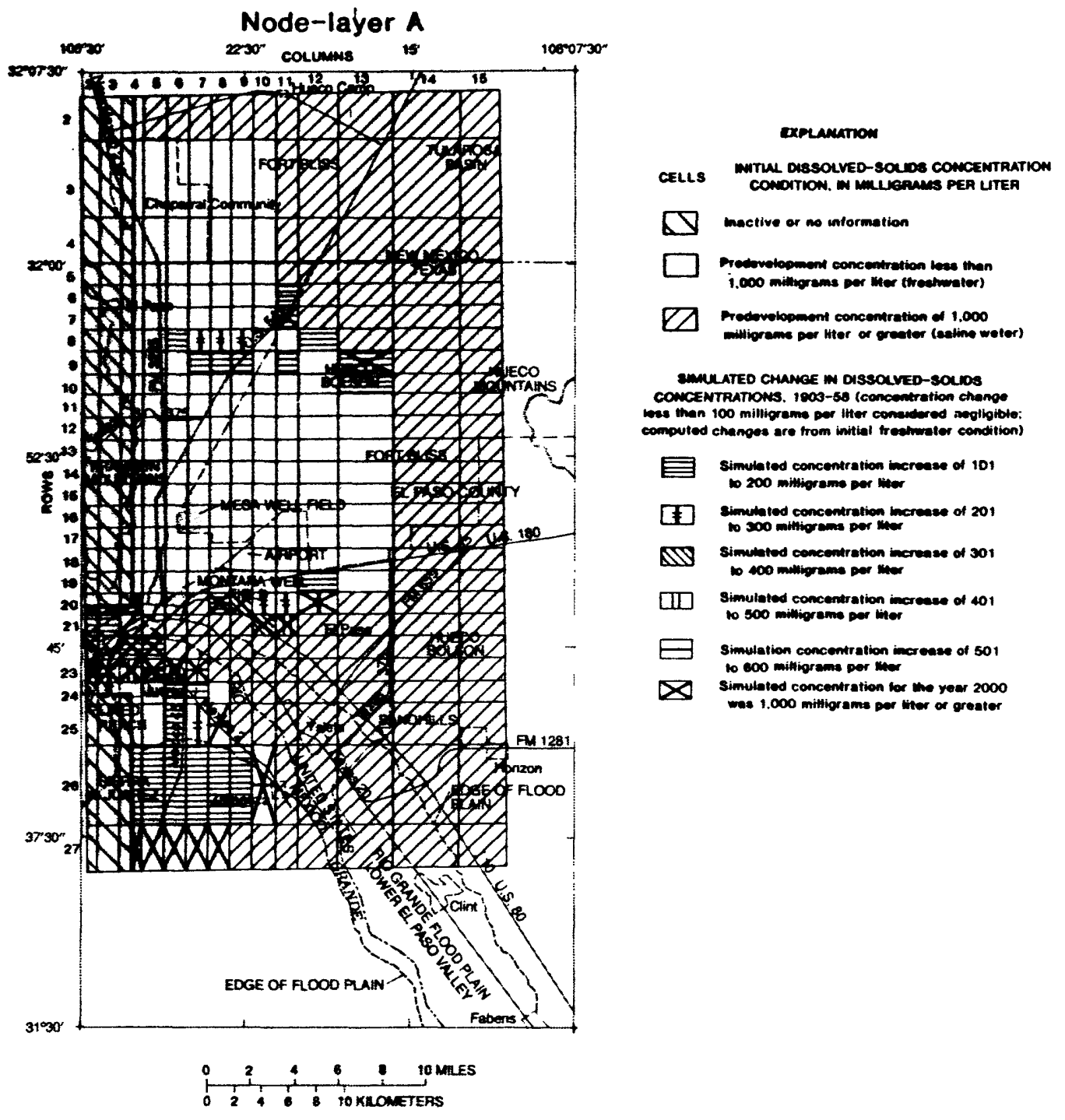

Figure 35. Simulated changes in dissolved-solids concentrations, 1984-2000, in node-layers A, B, and C of the Hueco bolson aquifer in response to the smaller estimate of projected (1984-2000) ground-water withdrawals. 

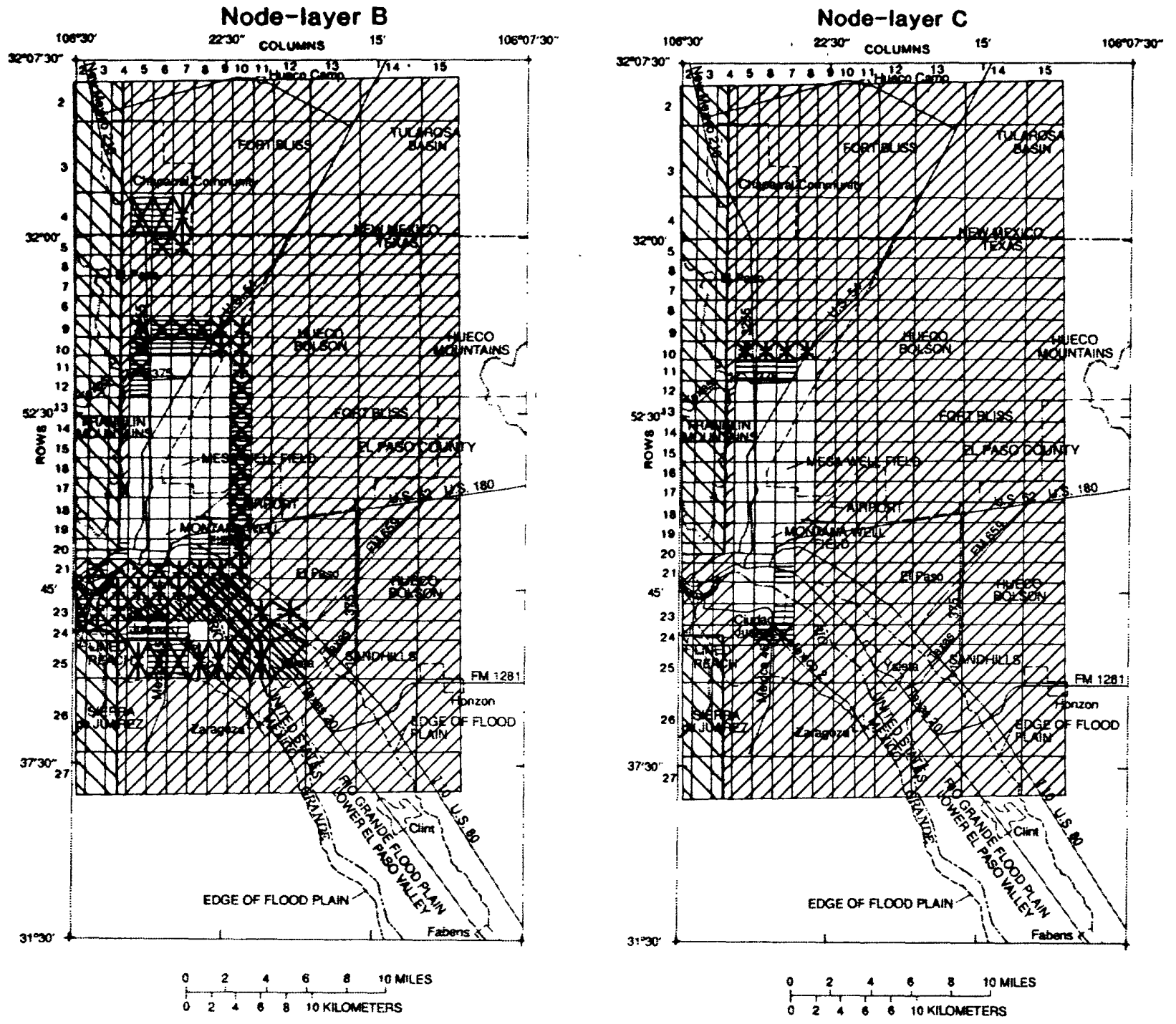


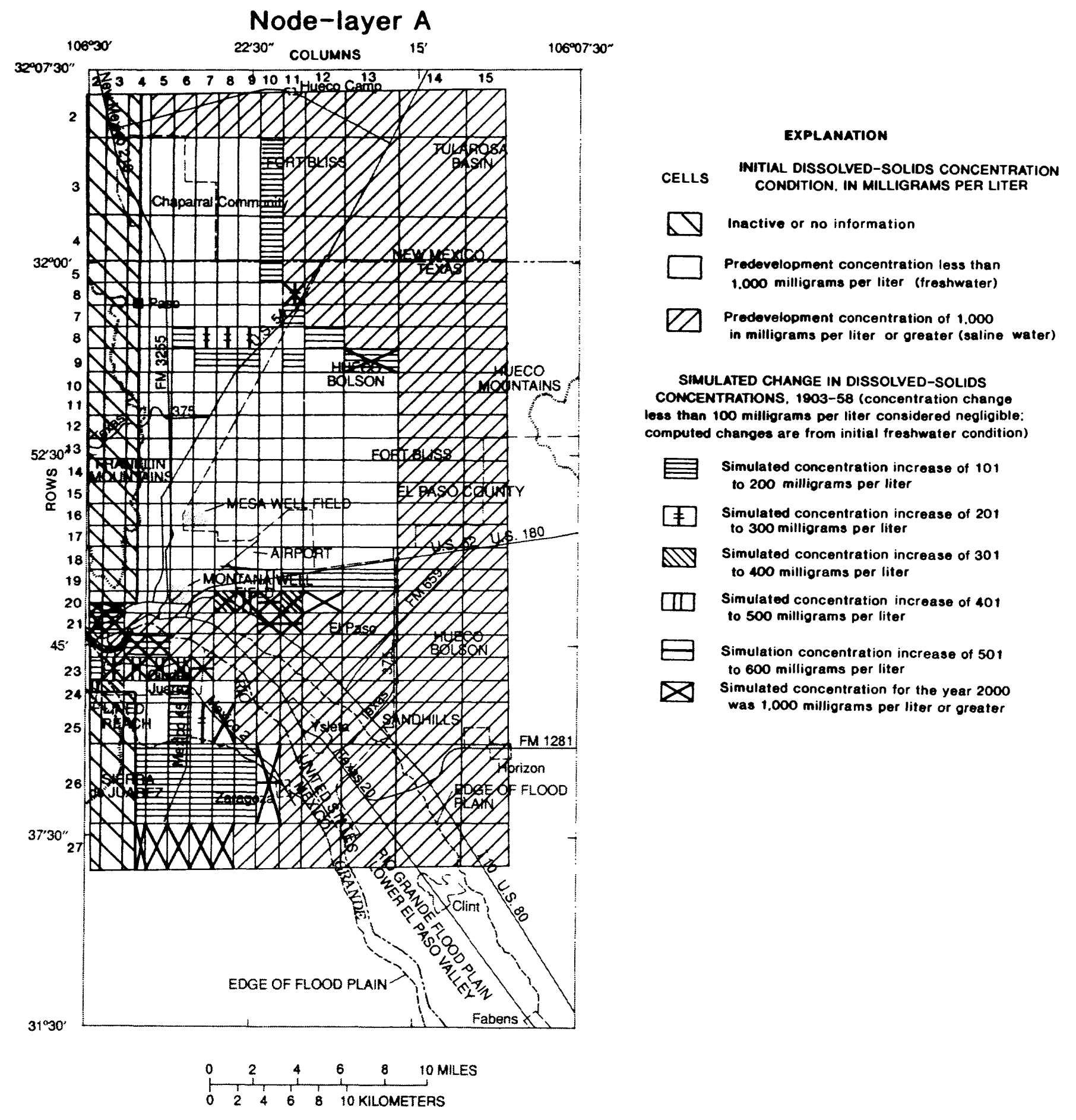

Figure 36. Simulated changes in dissolved-solids concentrations, 1984-2000, in node-layers A and B of the Hueco bolson aquifer in response to the larger estimate of projected (1984-2000) ground-water withdrawals. 


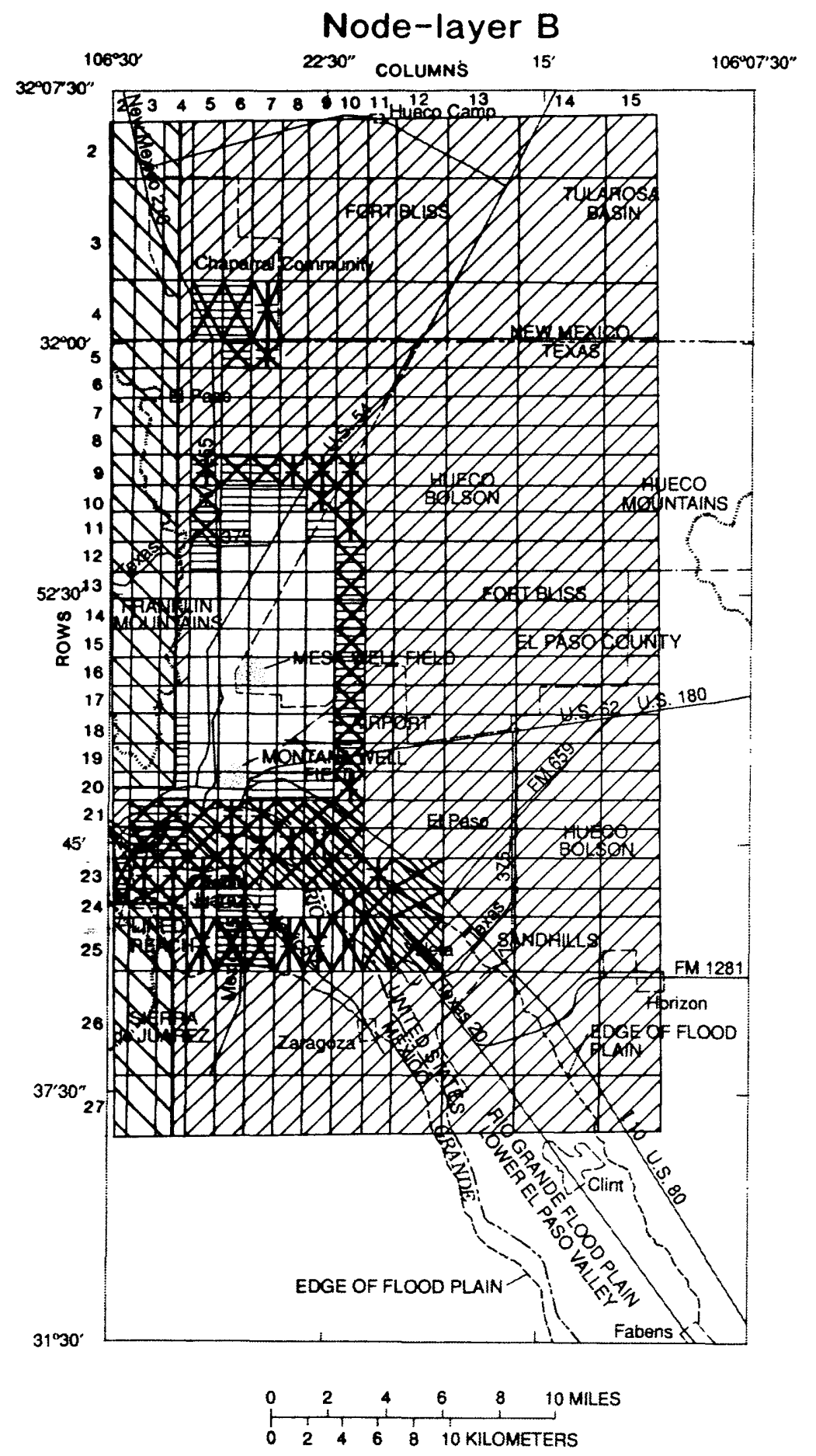


in or near the river alluvium in the topmost aquifer layer. At least part of these simulated changes could be caused by numerical dispersion and might not indicate projected saline-water movement accurately. The greatest movement of saline water in the top layer would be from the saline river deposits to the north near the airport and to the south under Ciudad Juarez. The projected movement of this saline water between 1983 and 2000 was, at most, about 2 to $3 \mathrm{mi}$ in both areas. The projected movement is complicated by the wells that draw water from these zones. The wells that continue to be pumped after the saline water begins to flow into them would block some lateral movement of the saline water to other wells by intercepting the saline water along flowpaths to wells locally. Any change in the pumping schedule of these wells could affect substantially the local and perhaps regional movement of the saline water by causing saline water to follow different flowpaths as a result of variation in time and location of pumping.

Over most of the area underlain by freshwater, little saline water would move toward wells. This is primarily because the wells are some distance away from the saline zones and because of the assumed relatively small permeability of the deposits in the saline zone. Some apparent movement of saline water in the eastern part of the aquifer could be the result of using inadequate data to define the permeability and salinity relations in those areas.

With the exception of some downward migration in the river area, no substantial vertical movement of saline water is projected for most of the simulation area (figs. 35 and 36). As indicated by the results of simulations discussed above and on the basis of the conceptual understanding of the anisotropy of the aquifer, the likelihood of upconing into wells is relatively small. If upconing was a problem, node-layers $C$ and $D$ would have had the greatest simulated increases in salinity. The changes in node-layer $\mathrm{C}$ were relatively small compared to the changes in node-layers A and B, and no substantial changes occurred in node-layer D.

\section{SUMMARY AND CONCLUSIONS}

The Hueco bolson aquifer is being pumped at increasing rates to supply water for El Paso, Texas, and Ciudad Juarez, Mexico. Water-use projections for 1984-2000 indicate that the present (1984) upward trend in pumping rates probably will continue, which will put an increasing burden on the limited freshwater resources of the aquifer.

The principal concern of the water-management agencies involved with the water supply of these cities, and of the U.S. Department of Defense at Fort Bliss, is that the saline water underlying and surrounding the freshwater in the bolson deposits will begin to move into the intensively pumped freshwater zone. Intrusion of large volumes of saline water would contaminate the freshwater and make it unusable for municipal and industrial supply.

Previous studies using analytical and numerical-simulation approaches did not address the movement of saline water for making projections of future aquifer conditions. This study focused primarily on the historical and projected aquifer conditions to simulate the historical and present (1984) salinity in the aquifer, to help understand and project the movement of saline water, and to estimate the salinity in the aquifer to January 2000.

The study was conducted in four phases. The first phase was the compilation of data and the review of previous studies. The second phase of the study was the simulation of flow during predevelopment conditions and during the historical period--1903 through 1983--based on previous two-dimensional models. The third phase was to simulate the flow conditions in the aquifer from 1984-2000. The fourth and final study phase was a three-dimensional solute-transport simulation of regional salinity changes prior to 1984 and for 1984-2000.

During the third and fourth phases of the study, tests were made of the effect of data uncertainty on the simulated results to estimate the reliability of the results. A better understanding of the effects of interference among wells and on the movement of saline water also was identified as a need. A series of large-scale hypothetical simulations was conducted to test the effect of a variety of conditions and aquifer properties on the movement of saline water near wells. The implications of these simulation results on upconing of saline water and on the apparent salinity of water produced from wells were examined.

Some important data on aquifer properties and conditions needed for this study were estimated from sparse field data, or a reasonable range of values from other studies was tested in the simulations. Although vertical 
hydraulic conductivity and recharge rates have a great effect on the accuracy of the simulation, little or no local field verification was available. Field information also was lacking on dispersivity, a property that has only a small effect on the regional-simulated dissolved-solids concentrations, but might substantially affect saline-water movement near individual wells.

Little is known about the vertical hydraulic conductivity, a property that has a great effect on simulated dissolved-solids concentrations. Interference between wells also is not totally understood. Sensitivity analysis of the probable interference among wells indicated that location of well screen intervals and relative withdrawal rates in closely spaced wells could have a major effect on simulated concentrations in an anisotropic aquifer. Finally, the large vertical grid spacing used in the simulations greatly affected the amount of vertical numerical dispersion. These aquifer properties and conditions need to be studied in greater detail for a more accurate and site-specific analysis of saline-water intrusion.

The specific results of ground-water flow and solute-transport simulations in the Hueco bolson aquifer for historical and projected periods indicated that:

1. Horizontal movement of saline water is more important than vertical movement because of the relatively large ratio of horizontal to vertical permeability (aquifer anisotropy);

2. The saline water in the Rio Grande alluvium was the major source of saline-water intrusion into the freshwater zone during the historical period and likely will continue as such in the near future; and

3. Some saline water moves downward from the Rio Grande alluvium into the freshwater zone below, but the large vertical grid spacing of the regional model could not accurately simulate vertical solute movement.

The results of the well-test simulations and the sensitivity analysis indicated that:

1. The vertical distribution of flow into a well screen can affect substantially the movement of saline water near the well;

2. Interference among closely-spaced wells with variable-length screened intervals or wells screened in vertically separate sections of the aquifer can create conditions of greater or lesser saline-water movement than would be expected if the wells were examined individually;

3. Flow reversal in well bores can cause freshwater or saline water to be drawn deep into the aquifer by other nearby wells; and

4. Upconing of saline water is not a substantial hazard to water quality in wells where the horizontal permeability is much greater than the vertical permeability such as in the Hueco bolson aquifer.

\section{SELECTED REFERENCES}

Alvarez, H.J., and Buckner, A.W., 1980, Ground-water development in the El Paso region, Texas, with emphasis on the resources of the lower El Paso Valley: Texas Department of Water Resources Report 246, $346 \mathrm{p}$.

Anderson, M.P., 1979, Using models to simulate the movement of contaminants through ground-water flow systems: Critical Review in Environmental Control, v. 9, no. 2, p. 97-156.

Bennett, G.D., Kontis, A.L., and Larson, S.P., 1982, Representation of multiaquifer well effects in three-dimensional groundwater flow simulation: Ground Water, v. 20, no. 3, p. 334-341.

Bluntzer, R.L., 1975, Selected water well and ground-water chemical analysis data, Ciudad Juarez, Chihuahua, Mexico: Texas Department of Water Resources Limited Distribution Report, 29 p.

Chapplelear, J.E., and Williamson, A.S., 1981, Representing wells in numerical reservoir simulation, Part 2--Implementation: Society of Petroleum Engineers Journal, v. 21, no. 3, p. 339-344.

Davis, M.E., 1965, Development of ground water in the El Paso District, Texas, 1960-63, Progress report no. 9: Texas Water Commission Bulletin 6514, 34 p.

Davis, S.N., and DeWiest, R.J.M., 1966, Hydrogeology: New York, Wiley, 463 p.

Fenneman, N.M., 1931, Physiography of western United States: New York, McGraw-Hill, 534 p.

Freeze, R.A., and Cherry, J.A., 1979, Ground water: Englewood Cliffs, N.J., Prentice-Hall, Inc., 604 p. 
Garza, Sergio, Weeks, E.P., and White, D.E., 1980, Appraisal of potential for injection-well recharge of the Hueco bolson with treated sewage effluent--preliminary study of the northeast El Paso area, Texas: U.S. Geological Survey Open-File Report 80-1106, $37 \mathrm{p}$.

Gates, J.S., White, D.E., Stanley, W.D., and Ackermann, H.D., 1978, Availability of fresh and slightly saline ground water in basins of westernmost Texas: U.S. Geological Survey Open-File Report 78-663, 115 p. (also published as Texas Department of Water Resources Report 256, 1980).

Guven, Oktay, Molz, F.J., and Melville, J.G., 1984, An analysis of dispersion in a stratified aquifer: Water Resources Research, v. 20, no. 10, p. 1,337-1,354.

INTERA Environmental Consultants, Inc., 1979, Revision of the documentation for a model for calculating effects of liquid waste disposal in deep saline aquifers: U.S. Geological Survey Water-Resources Investigations Report 79-96, 79 p.

INTERCOMP Resource Development and Engineering, Inc., 1976, A model for calculating effects of liquid waste disposal in deep saline aquifers, Part I--Development and Part II--Documentation: U.S. Geological Survey Water-Resources Investigations Report 76-61, 263 p.

Kipp, K.L., Jr., 1987, HST3D--a computer code for simulation of heat and solute transport in three-dimensional ground-water flow systems: U.S. Geological Survey Water-Resources Investigations Report 86-4095, 517 p.

Knowles, D.B., and Kennedy, R.A., 1958, Ground-water resources of the Hueco bolson, northeast of El Paso, Texas: U.S. Geological Survey Water-Supply Paper 1426, 186 p. (also published as Texas Board of Water Engineers Bulletin 5615, 1956).

Knowles, T.R., and Alvarez, J.H., 1979, Simulated effects of ground-water pumping in portions of the Hueco bolson in Texas and Mexico during the period 1973 through 2029: Texas Department of Water Resources Report LP-104, $26 \mathrm{p}$.

Konikow, L.F., 1978, Calibration of ground-water models, in Conference on Verification of Mathematical and Physical Models in Hydraulic Engineering: College Park, Md., American Society of Civil Engineers, p. 87-92.

Kuniansky, J., and Hillestad, J.G., 1980, Reservoir simulation using bottom-hole pressure boundary conditions: Society of Petroleum Engineers Journal, v. 20, p. 473-486.

Land, L.F., and Armstrong, C.A., 1985, A preliminary assessment of land-surface subsidence in the El Paso area, Texas: U.S. Geological Survey Water-Resources Investigations Report 85-4155, 96 p.

Lantz, R.B., 1970, Quantitative evaluation of numerical diffusion (truncation error): Transactions of the Society of Petroleum Engineers of the American Institute of Mining, Metallurgical, and Petroleum Engineers, v. 251, p. 315-320.

Lee Wilson and Associates, Inc., 1981, Water supply alternatives for El Paso: Unpub. consultant's report prepared for the El Paso Water Utilities-Public Service Board, 75 p.

1986, Projections of Public Service Board demands on Hueco bolson of Texas under a radical depletion strategy:

Water resources analysis for El Paso Public Service Board, v. 1, p. 5-1.

1991, Solute transport model of Hueco Bolson Recharge Project: Research memorandum no. 3, prepared for El Paso Water Utilities-Public Service Board, 148 p.

Leggat, E.R., 1962, Development of ground water in the El Paso district, Texas, 1955-60, Progress report No. 8: Texas Water Commission Bulletin 6204, 65 p.

Leggat, E.R., and Davis, M.E., 1966, Analog model study of the Hueco bolson near El Paso, Texas: Texas Water Development Board Report 28, 26 p.

Leggat, E.R., Lowry, M.E., and Hood, J.W., 1963 [1964], Ground-water resources of the lower Mesilla Valley, Texas and New Mexico: U.S. Geological Survey Water-Supply Paper 1669-AA, 49 p. (also published as Texas Water Commission Bulletin 6203, 1962).

Lippincott, J.B., 1921, Memorandum reports on El Paso water system: Unpub. consultant's reports for the City Water Board, El Paso, as cited in U.S. Geological Survey Water-Supply Paper 919, by A.N. Sayre.

Marston, R.A., and Lloyd, W.J., 1985, River budget for the Rio Grande, El Paso-Juarez Valley: Journal of Arid Environment, v. 8, no. 2, p. 109-119.

McDonald, M.G., 1985, Development of a multi-aquifer well option for a modular ground-water flow model, in Symposium on Practical Application of Ground-Water Models, August 1985: Columbus, Ohio.

McDonald, M.G., and Harbaugh, A.W., 1988, A modular three-dimensional finite-difference ground-water flow model: U.S. Geological Survey Techniques of Water-Resources Investigations Report, book 6, chap. A1, 576 p.

Meyer, W.R., 1976, Digital model for simulated effects of ground-water pumping in the Hueco bolson, El Paso area, Texas, New Mexico, and Mexico: U.S. Geological Survey Water-Resources Investigations Report 58-75, 31 p.

Meyer, W.R., and Gordon, J.D., 1972, Development of ground water in the El Paso district, Texas, 1963-70: Texas Water Development Board Report 153, 50 p. 
1973, Water-budget studies of lower Mesilla Valley and El Paso Valley, El Paso County, Texas: Austin, Texas, U.S. Geological Survey Open-File Report, 43 p.

Ogata, Akio, 1970, Theory of dispersion in a granular medium: U.S. Geological Survey Professional Paper 411-I, 34 p. Richardson, G.B., 1909, El Paso, Texas, folio: U.S. Geological Survey Geologic Atlas of the United States No. 166, 11 p. Sayre, A.N., and Livingston, Penn, 1945, Ground-water resources of the El Paso area, Texas: U.S. Geological Survey WaterSupply Paper 919, 190 p.

Slichter, C.J., 1905, Observations on the ground waters of the Rio Grande Valley: U.S. Geological Survey Water-Supply Paper $141,83 \mathrm{p}$.

Sudicky, E.A., Gillham, R.W., and Frind, E.O., 1985, Experimental investigation of solute transport in stratified porous media--1. The nonreactive case: Water Resources Research, v. 21, no. 7, p. 1,035-1,041.

Sykes, J.F., Pahwa, S.B., Lantz, R.B., and Ward, D.S., 1982, Numerical simulation of flow and contaminant migration at an extensively monitored landfill: Water Resources Research, v. 18, no. 6, p. 1,687-1,704.

Thomas, G.W., 1982, Principles of hydrocarbon reservoir simulation (2d ed.): Boston, International Human Resources Development Corp., 208 p.

Toth, J., 1978, Gravity-induced cross-formational flow of formation fluids, Red Earth region, Alberta, Canada--analysis, patterns, evolution: Water Resources Research, v. 14, no. 5, p. 805-843.

U.S. Bureau of Reclamation, 1973, Water resources of El Paso County, Texas: Unpub. report prepared by the Rio Grande Project, New Mexico-Texas Project Office, El Paso, Texas, for the Texas Water Development Board, Austin, Texas.

U.S. Geological Survey, 1985, National water summary 1984, hydrologic events, selected water-quality trends, and groundwater resources: U.S. Geological Survey Water-Supply Paper 2275, 467 p.

Vidal de Los Santos, E., 1982, La contamination bacteriologica de las corrientes subterraneas que abastacen a Ciudad Juarez, Chihuahua: Thesis Profesional, Escuela Nacional de Estudios Profesionales, Universidad Nacional Autonoma de Mexico, San Juan Iztcal, Mexico, 93 p.

White, D.E., 1983, Summary of hydrologic information in the El Paso, Texas, area, with emphasis on ground-water studies, 1903-80: U.S. Geological Survey Open-File Report 83-775, 77 p. (also published as Texas Water Development Board Report 300, 1987).

White, D. E., and Sladek, G.J., 1990, Summary of data from the 1981-83 pilot study and 1985-89 operations of the Hueco Bolson Recharge Project, northeast El Paso, Texas: U.S. Geological Survey Open-File Report 90-175, 38 p.

Williamson, A.S., and Chappelear, J.E., 1981, Representing wells in numerical reservoir simulation--Part I--Theory: Society of Petroleum Engineers Journal, v. 21, no. 3, p. 323-338.

Winslow, A.G., and Kister, L.R., 1956, Saline-water resources of Texas: U.S. Geological Survey Water-Supply Paper 1365, $105 \mathrm{p}$. 